Prepared in cooperation with the Ohio Water Development Authority

\title{
Chemical and Isotopic Characteristics of Methane in Groundwater of Ohio, 2016
}

Scientific Investigations Report 2018-5097 



\section{Chemical and Isotopic Characteristics of Methane in Groundwater of Ohio, 2016}

By Mary Ann Thomas

Scientific Investigations Report 2018-5097 


\title{
U.S. Department of the Interior \\ RYAN K. ZINKE, Secretary
}

\author{
U.S. Geological Survey \\ James F. Reilly II, Director
}

U.S. Geological Survey, Reston, Virginia: 2018

For more information on the USGS - the Federal source for science about the Earth, its natural and living resources, natural hazards, and the environment-visit https://www.usgs.gov/ or call 1-888-ASK-USGS (1-888-275-8747).

For an overview of USGS information products, including maps, imagery, and publications, visit https://store.usgs.gov/.

Any use of trade, firm, or product names is for descriptive purposes only and does not imply endorsement by the U.S. Government.

Although this information product, for the most part, is in the public domain, it also may contain copyrighted materials as noted in the text. Permission to reproduce copyrighted items must be secured from the copyright owner.

Suggested citation:

Thomas, M.A., 2018, Chemical and isotopic characteristics of methane in groundwater of Ohio, 2016: U.S. Geological Survey Scientific Investigations Report 2018-5097, 42 p., https://doi.org/10.3133/sir20185097.

ISSN 2328-031X (print)

ISSN 2328-0328 (online) 


\section{Contents}

Abstract

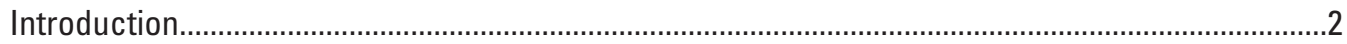

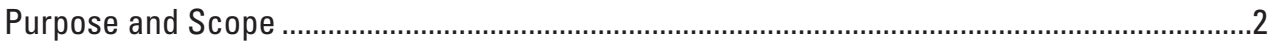

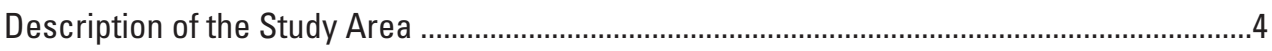

Background and Previous Studies ........................................................................................

Methods Used to Evaluate Methane Origin ....................................................................

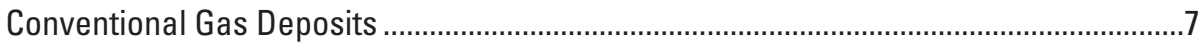

Unconventional Gas Deposits .........................................................................................

Methane in Water Wells................................................................................................

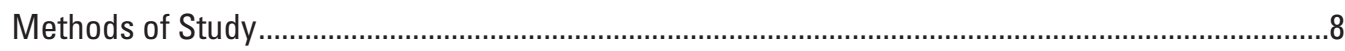

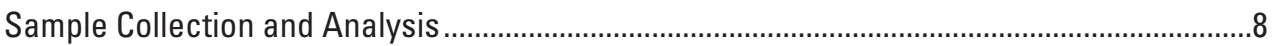

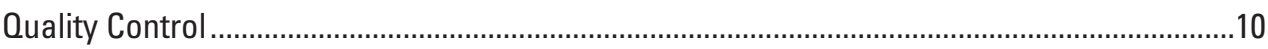

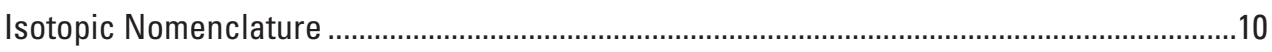

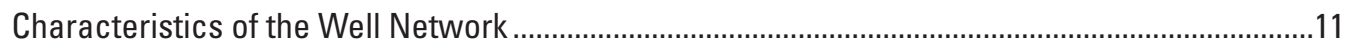

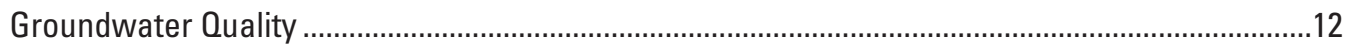

Dissolved Gases and Methane Concentrations …………....................................................12

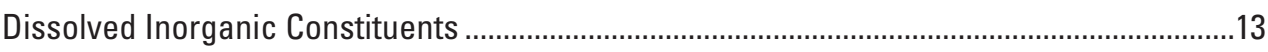

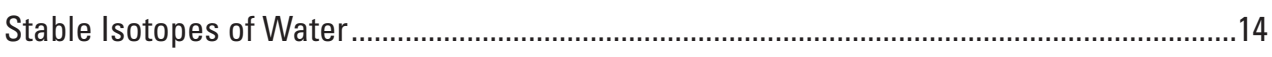

Chemical and Isotopic Characteristics of Methane and Related Constituents ..............................15

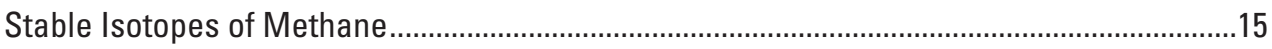

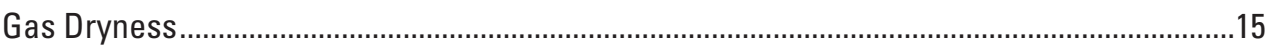

Isotopic Characteristics of Microbial Methane ……..........................................................17

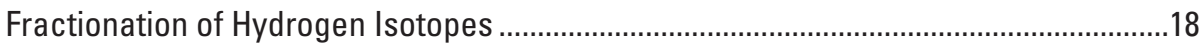

Carbon Isotope System ..........................................................................................19

Carbon-13 of Dissolved Inorganic Carbon..............................................................19

Fractionation of Carbon Isotopes........................................................................19

Rayleigh-Type Fractionation ............................................................................21

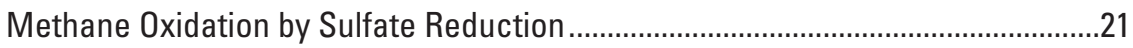

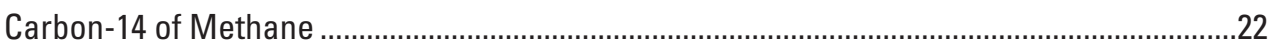

Interpretation of Methane Origin ..........................................................................................2

Samples with Chemical and Isotopic Characteristics Consistent with Microbial Methane..............................................................................................24

Samples with Chemical and Isotopic Characteristics not Consistent
with Microbial Methane

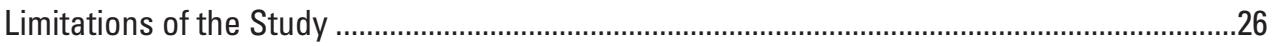

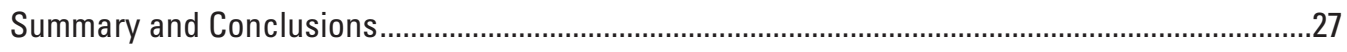

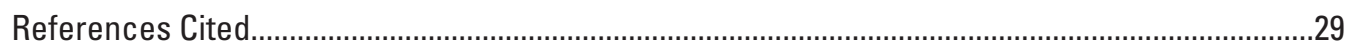




\section{Figures}

1. Maps showing location of Ohio counties and wells included in a study of methane in domestic wells, 2016 .

2. Maps showing geology of the study area. $A$, Major structural features of Ohio and surrounding States. B, Location of domestic wells sampled for methane (2016) in relation to bedrock formations of Ohio .

3. Map showing location of domestic wells sampled for methane (2016) in relation to the extent and thickness of glacial deposits in Ohio

4. Graph showing composition of headspace gases in water samples from domestic wells in Ohio, 2016

5. Graph showing methane concentrations in water samples from domestic wells in Ohio, 2016

6. Graph showing stable isotopes of water from domestic wells in Ohio, 2016

7. Graphs showing gas classification diagrams showing samples from domestic wells in Ohio. $A$, Whiticar plot. $B$, Bernard plot.

8. Graph showing relation between the stable hydrogen isotopic signature of water and methane for samples from domestic wells in Ohio, 2016

9. Graphs showing stable carbon isotopic signature $\left(\delta^{13} \mathrm{C}\right)$ of methane in relation to $A$, $\delta^{13} \mathrm{C}$ of dissolved inorganic carbon and $B, \delta^{13} C$ of carbon dioxide and $\delta^{13} \mathrm{C}$ fractionation factors for samples from Ohio domestic wells, 2016

10. Graph showing carbon-14 of methane from domestic wells in Ohio, 2016.....................22

11. Graph showing stable carbon isotopic signature of methane in relation to well depth and geologic formation for 12 samples interpreted as microbial methane formed by carbon dioxide reduction in Ohio domestic wells, 2016.

\section{Tables}

1. Methods used for collection and analysis of water-quality samples.

2. Results of quality-control samples analyzed at U.S. Geological Survey National Water Quality Laboratory

3. Results of quality-control samples analyzed at Isotech Laboratories and U.S. Geological Survey Reston Groundwater Dating Laboratory.

4. Characteristics of Ohio domestic wells sampled for methane, 2016 ...

5. Water-quality data from Ohio domestic wells, 2016

6. Methane concentrations and selected water-quality constituents from Ohio domestic wells, 2016 .

7. Chemical and isotopic characteristics of methane and related constituents from domestic wells in Ohio, 2016. 


\section{Conversion Factors}

U.S. customary units to International System of Units

\begin{tabular}{|c|c|c|}
\hline Multiply & By & To obtain \\
\hline \multicolumn{3}{|c|}{ Length } \\
\hline foot $(\mathrm{ft})$ & .03048 & $\operatorname{meter}(\mathrm{m})$ \\
\hline mile (mi) & 1.609 & kilometer (km) \\
\hline \multicolumn{3}{|c|}{ Volume } \\
\hline gallon (gal) & 3.785 & liter $(\mathrm{L})$ \\
\hline \multicolumn{3}{|c|}{ Mass } \\
\hline ounce, avoirdupois & 28.35 & $\operatorname{gram}(\mathrm{g})$ \\
\hline
\end{tabular}

\section{Supplemental Information}

Specific conductance is given in microsiemens per centimeter at 25 degrees Celsius $(\mu \mathrm{S} / \mathrm{cm}$ at $\left.25^{\circ} \mathrm{C}\right)$.

Concentrations of chemical constituents in water are given in milligrams per liter $(\mathrm{mg} / \mathrm{L})$ or micrograms per liter $(\mu \mathrm{g} / \mathrm{L})$. 


\section{Abbreviations}

$\begin{array}{ll}\mathrm{BLS} & \text { below land surface } \\ \mathrm{CaCO}_{3} & \text { calcium carbonate } \\ \mathrm{CH}_{4} & \text { methane } \\ \mathrm{Cl} & \text { chloride } \\ \mathrm{CO}_{2} & \text { carbon dioxide } \\ \mathrm{CO}_{3} & \text { carbonate } \\ \delta & \text { delta (stable isotope notation) } \\ \mathrm{DIC} & \text { dissolved inorganic carbon } \\ \mathrm{GMWL} & \text { Global Meteoric Water Line } \\ \mathrm{HCO}_{3} & \text { bicarbonate } \\ \mathrm{H}_{2} \mathrm{CO}_{3} & \text { carbonic acid } \\ \mathrm{H}_{2} \mathrm{O} & \text { water } \\ \mathrm{Mg} & \text { magnesium } \\ \mathrm{Na} & \text { sodium } \\ \mathrm{NO}_{3} & \text { nitrate } \\ \mathrm{per} \mathrm{mil} & \text { parts per thousand } \\ \mathrm{pMC} & \text { percent modern carbon } \\ \mathrm{SO}_{4} & \text { sulfate } \\ \mathrm{USGS} & \text { U.S. Geological Survey }\end{array}$




\title{
Chemical and Isotopic Characteristics of Methane in Groundwater of Ohio, 2016
}

\author{
By Mary Ann Thomas
}

\section{Abstract}

In 2016, the U.S. Geological Survey, in cooperation with the Ohio Water Development Authority, investigated the hydrogeologic setting, chemical and isotopic characteristics, and origin of methane in groundwater of Ohio. Understanding the occurrence and distribution of methane in groundwater is important in terms of public safety because methane in water wells can pose a risk of explosion. In addition, documenting the chemical and isotopic characteristics of methane in groundwater can make an important contribution to future stray gas investigations.

Water samples were collected from 15 domestic water wells known to produce methane, which were in 12 counties in diverse parts of Ohio. The wells were 75-345 feet deep and tapped a range of aquifer types, including glacial deposits and bedrock of Upper Ordovician, Upper Devonian, Lower Mississippian, and Pennsylvanian ages. Although the hydrogeologic settings were varied, there was a broad similarity among the well sites in that the bedrock was predominantly shale and the glacial deposits were predominantly clay.

The wells were sampled for dissolved inorganic constituents; dissolved organic carbon; methane and other dissolved gases; stable isotopes (carbon, hydrogen, and oxygen) of methane, water, and dissolved inorganic carbon; and carbon-14 of methane. Gas composition and stable isotopes of methane were used to differentiate thermogenic and microbial methane. The degree of fractionation of hydrogen and carbon isotopes was used to evaluate the pathway of microbial methanogenesis (carbon dioxide $\left[\mathrm{CO}_{2}\right]$ reduction or acetate fermentation) and the effects of secondary processes such as oxidation, mixing, and migration. The concentration of carbon-14 of methane was used to evaluate the relative age of the carbon source.

The quality of water from the 15 wells differed greatly; water types ranged from $\mathrm{CaMgHCO}_{3}$ to $\mathrm{NaCl}$, and total dissolved solids concentrations ranged from 318 to 2,940 milligrams per liter $(\mathrm{mg} / \mathrm{L})$. Methane concentrations ranged from 1.2 to $120 \mathrm{mg} / \mathrm{L}$. Of the 15 samples, 12 had methane concentrations greater than $28 \mathrm{mg} / \mathrm{L}$, the level that can pose a risk of explosion.
Of the 15 samples, 12 had chemical and isotopic characteristics or "signatures" consistent with microbial methane formed by $\mathrm{CO}_{2}$ reduction. $\mathrm{CO}_{2}$ reduction is commonly associated with microbial degradation of organic matter in anaerobic aquifers and with the formation of microbial shale gas and coalbed methane along margins of sedimentary basins. Two of 15 samples were interpreted as having a component of thermogenic methane based on the $\delta^{13} \mathrm{C}$ of methane ( -50.96 and -47.74 parts per thousand [per mil]) and gas dryness (28 and 5). One of 15 samples (from the shallowest well) had chemical and isotopic characteristics consistent with methane oxidation by sulfate reduction based on light $\delta^{13} \mathrm{C}$ of dissolved inorganic carbon ( -31.6 per mil) and evidence of sulfate reduction in terms of the odor and appearance of the water.

For the 12 samples interpreted as microbial methane formed by $\mathrm{CO}_{2}$ reduction, the $\delta^{13} \mathrm{C}$ of methane varied from -75 to -56 per mil. Multiple samples from the same aquifer demonstrated a general trend of increasing $\delta^{13} \mathrm{C}$ of methane with depth. Samples with lighter $\delta^{13} \mathrm{C}$ of methane ( -75 to -62 per mil) were from shallower wells (or wells with shallow open intervals), and the isotopic signature of the water was consistent with modern or postglacial groundwater recharge. Three samples with heavier $\delta^{13} \mathrm{C}$ of methane ( -61 to -56 per mil) were from deeper wells or more confined aquifers, where the isotopic signature of water was consistent with older (glacial) recharge. In addition, $\delta^{13} \mathrm{C}$ of dissolved inorganic carbon was enriched ( +12 to +18.9 per mil), and carbon- 14 of methane was consistent with carbon associated with Paleozoic bedrock or older glacial deposits. These observations are generally consistent with increased Rayleigh-type fractionation at greater depths; however, other interpretations are possible. Isotopic signatures can be ambiguous, especially in areas with complex geologic histories that include multiple episodes of migration, mixing, and (or) oxidation.

Many of the wells were in proximity to multiple potential natural and anthropogenic pathways of methane migration; however, it is not possible to determine if the methane in any of the wells is related to human activities based on the chemical and isotopic data collected for this study. 


\section{Introduction}

Methane $\left(\mathrm{CH}_{4}\right)$ is a gas that forms from the breakdown of organic matter in a variety of environments. Thermogenic methane forms in the deep subsurface, where high temperatures transform sedimentary organic matter into conventional hydrocarbon deposits. Methane also forms by microbial processes (microbial methanogenesis) in shallower environments such as landfills, wetlands, marshes, and marine sediments. Conditions conducive to microbial methanogenesis also exist in parts of the groundwater system.

It is generally known that methane can exist naturally in groundwater; however, little is known about its occurrence and distribution in Ohio groundwater. When well water is pumped to the surface, decreasing pressure causes dissolved methane to come out of solution. If methane accumulates in a closed space, such as a well housing or basement, an explosive environment can form; immediate preventative action is recommended if methane concentrations greater than 28 milligrams per liter $(\mathrm{mg} / \mathrm{L})$ are detected in a water well (Eltschlager and others, 2001). An increased understanding of where methane is most likely to occur would allow public-safety education to be directed to areas of greatest need.

When a rare explosion does occur, it can be important to determine whether the methane formed by natural processes in the aquifer or migrated from another location as stray gas. This can be difficult to discern because of the prevalence and variety of potential sources of methane and the general lack of information about naturally occurring methane in groundwater of Ohio. For example, are there chemical or isotopic characteristics that distinguish natural methane in groundwater from other sources, especially those linked to anthropogenic activities such as oil/gas production, coal mining, or landfills? Do the chemical isotopic characteristics of natural methane differ among aquifers? This type of information could contribute to future investigations of suspected contamination of groundwater by stray gas.

In 2016, the U.S. Geological Survey (USGS), in cooperation with the Ohio Water Development Authority, began an investigation to increase understanding of the occurrence and chemical/isotopic characteristics of methane in Ohio aquifers.

\section{Purpose and Scope}

This report presents results of an investigation of methane in groundwater of Ohio. The objectives were to (1) identify a network of domestic wells that produce methane, (2) describe the hydrogeologic settings in which methane is detected, (3) document the chemical and isotopic characteristics of the methane and the coexisting water, and (4) evaluate the origin of the methane, to the extent possible. The goal was to select wells that produce methane that is unrelated to human activities.

A total of 15 domestic water wells were selected from 12 counties in diverse parts of Ohio (fig. 1). The wells were sampled once during 2016 and analyzed for field parameters; dissolved chemical constituents; dissolved gases; and carbon, hydrogen, and oxygen isotopes of methane, water, and dissolved inorganic carbon. Well logs and geologic spatial coverages were used to describe the hydrogeologic settings of the well sites. The nature and origin of methane was evaluated using methods attributed to Whiticar and others (1986), Whiticar (1999), Schoell (1980, 1988), Bernard and others (1978), and Coleman and others $(1988,1995)$. 


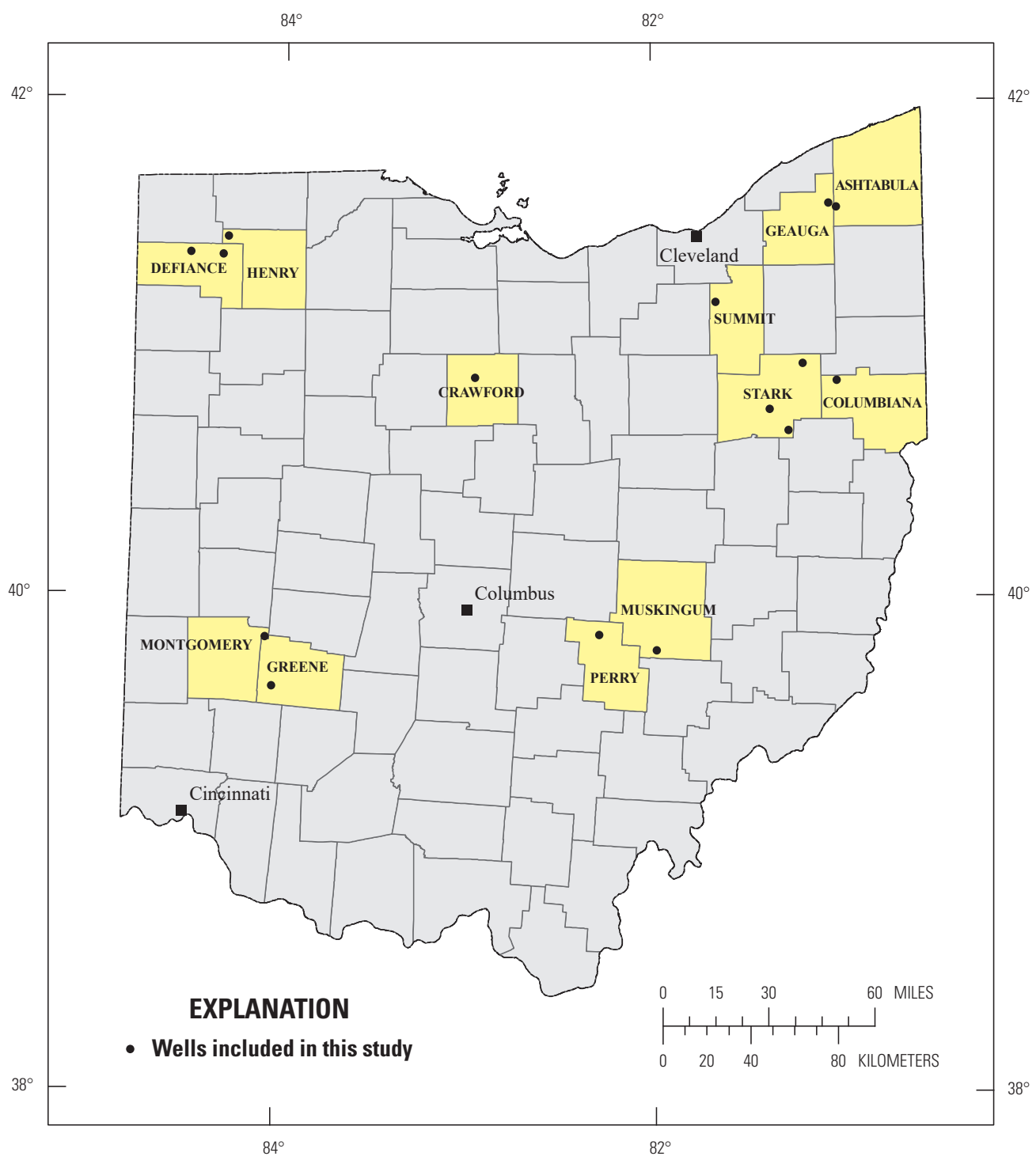

Base from U.S. Geoloaical Survev diqital data. National Map 2015. StatePlane Ohio South. North American Datum of 1983

Figure 1. Location of Ohio counties and wells included in a study of methane in domestic wells, 2016. 


\section{Description of the Study Area}

Ohio is underlain by bedded sedimentary rocks that were deformed into broad arches and basins (fig. 2A). The Cincinnati and Findlay Arches underlie the Indiana-Ohio Platform in western Ohio, an area where bedrock is nearly flat lying. The northwestern corner of Ohio is along the southern margin of the Michigan Basin, where bedrock formations dip gently toward the north and northwest. Eastern Ohio is along the western margin of the Appalachian Basin, where bedrock formations dip gently toward the east and southeast. The sedimentary strata are about 2,500 feet (ft) thick in western Ohio, and increase to more than $13,000 \mathrm{ft}$ thick in southeastern Ohio (Coogan, 1996). The strata are displaced by multiple fault systems, some of which extend to basement rocks (Baranoski, 2013).

The bedrock formations at land surface (or beneath glacial deposits) range in age from Ordovician to Upper Pennsylvanian/Lower Permian (fig. 2B) (Slucher and others, 2006). Upper Ordovician bedrock, which consists of interbedded shale and limestone, subcrops in southwestern Ohio near the Cincinnati Arch. Silurian bedrock, which consists of dolomite and lesser amounts of shale, subcrops in western Ohio. Devonian strata subcrop in the northwest corner of the State, along Lake Erie in Northern Ohio, and in a north-south trending band in central Ohio. Lower and Middle Devonian rocks are predominantly carbonates and shale, and Upper Devonian strata are organic-rich shales and sandstone. Mississippian bedrock, which consists of interbedded shales and sandstones, subcrops in eastern Ohio. Pennsylvanian and Lower Permian strata consist of alternating sequences of shale, sandstone, siltstone, limestone, and coal. These rocks subcrop in eastern and southeastern Ohio.

For about two-thirds of the State, bedrock is overlain by unconsolidated sediments, most of which were deposited during the most recent episode of Pleistocene glaciation (fig. 3). The deposits are predominantly fine grained and range in thickness from 0 to more than $700 \mathrm{ft}$ (Ohio Department of Natural Resources, Division of Geological Survey, 2004b). The thickest glacial deposits are in deep buried valleys cut into bedrock by the ancient Teays River system. Groundwater used for drinking water is produced from glacial deposits and (or) bedrock. The largest groundwater supplies are from glacial outwash beneath principal streams and Silurian carbonate bedrock (Eberts and George, 2000). Shales provide sufficient water for domestic use in most areas.

Ohio has a long history of coal mining and oil/gas (hydrocarbon) production. Coal is mined from Pennsylvanian and Permian bedrock in eastern and southeastern Ohio, and extensive fields of coal bed methane are in Harrison County (Ohio Department of Natural Resources, Division of Geological Survey, 2004a). Hydrocarbons are produced from a wide range of depths $(50-9,100 \mathrm{ft}$ ) and geologic formations (Cambrian to Pennsylvanian), and commercial quantities of hydrocarbons have been identified in 67 of the 88 counties (Ohio Department of Natural Resources, Division of Geological Survey, 2004a). During the early 1900s, large volumes of oil were produced from Upper Ordovician Trenton Limestone in northwestern Ohio, but production has diminished. Since then, most of the hydrocarbon production has been from the eastern one-third of the State, where conventional wells have been used to produce hydrocarbons from sandstones of CambrianPennsylvanian-ages. Since about 2008, horizontal drilling and hydraulic fracturing have been used to extract unconventional shale gas, primarily from the Upper Ordovician age Utica Shale along the eastern and southeastern margins of the State.

A large percentage of hydrocarbons in Ohio are sourced from organic-rich Devonian shale in deep parts of the Appalachian, Michigan, and Illinois Basins, where the rocks are thermally mature (East and others, 2012). However, most of the Devonian shale in Ohio is thermally immature, indicating that hydrocarbons in Devonian or younger bedrock migrated from deeper in the basin or are of microbial origin (East and others, 2012). 
$\boldsymbol{A}$

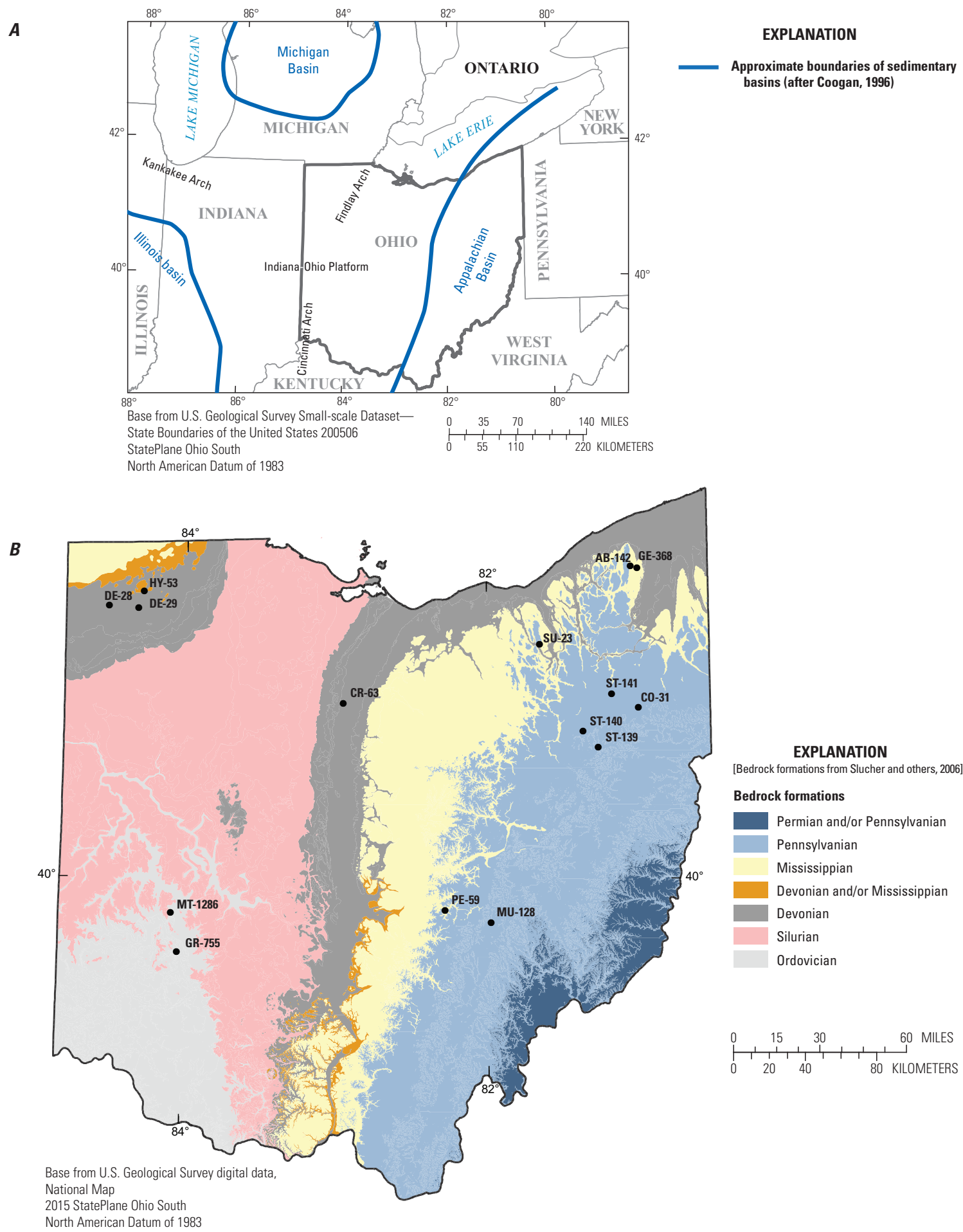

EXPLANATION

Figure 2. Geology of the study area. A, Major structural features of Ohio and surrounding States. $B$, Location of domestic wells sampled for methane (2016) in relation to bedrock formations of Ohio. 


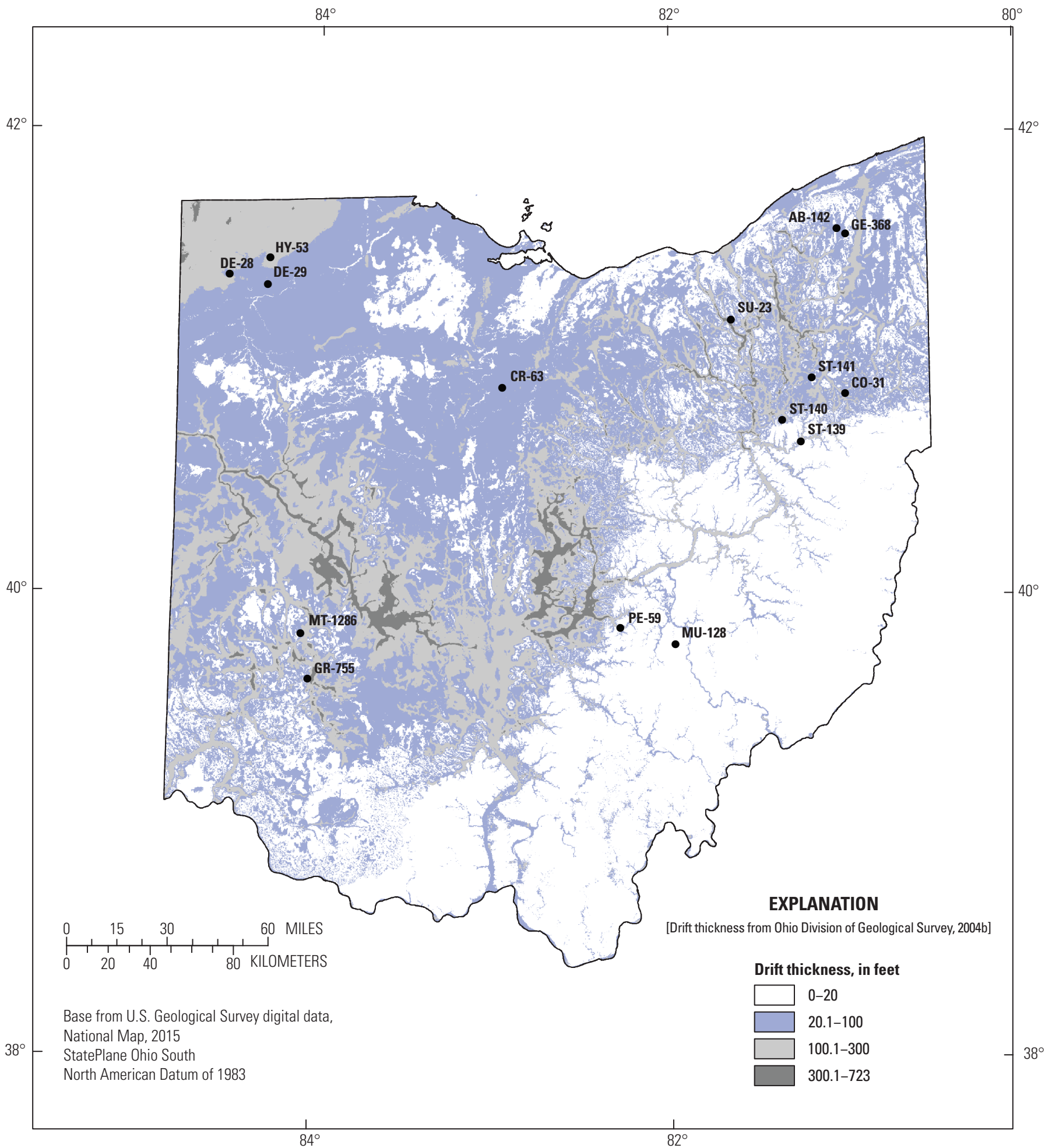

Figure 3. Location of domestic wells sampled for methane (2016) in relation to the extent and thickness of glacial deposits in Ohio. 


\section{Background and Previous Studies}

Methane forms from the breakdown of organic matter by thermal or microbial processes. Thermogenic methane forms in the deep subsurface, where high temperatures and pressures crack complex organic compounds into successively simpler compounds, the simplest of which is methane. In contrast, microbial methane forms in shallower, lower-temperature environments as a byproduct of microbial reduction of organic matter. Acetate fermentation is the predominant microbial pathway in near-surface environments, and carbon dioxide $\left(\mathrm{CO}_{2}\right)$ reduction is the predominant pathway in groundwater systems and marine sediments (Whiticar and others, 1986; Whiticar, 1999; Schoell, 1980, 1988).

\section{Methods Used to Evaluate Methane Origin}

The isotopic composition of methane is partly related to the environment of formation. Isotopes are atoms of the same element with different numbers of neutrons and, therefore, slightly different masses. Although the mass differences are minor, they can be sufficient to cause isotope fractionation, whereby isotopes preferentially partition into one phase or another. Isotope fractionation occurs during some microbial processes because microbes preferentially select lighter isotopes, which have weaker bonds that are easier to break. Partly as a result of isotope fractionation, methane formed by microbial processes is isotopically lighter than thermogenic methane, and this difference has been widely used as an indicator of methane origin (Schoell, 1980; Whiticar, 1999).

Another characteristic used to differentiate thermogenic and microbial methane is gas composition, specifically, the ratio of methane to higher-chain hydrocarbons. Because thermogenic gas forms by cracking apart complex organic compounds, it typically contains substantial concentrations of higher-chain hydrocarbons. In contrast, microbial processes produce gas that is predominantly methane, and has only minor amounts of ethane and propane (Bernard and others, 1978).

Gas classification diagrams based on gas composition and (or) stable isotopes of methane have been used to evaluate the origin of methane (Whiticar and others, 1986; Whiticar, 1999; Schoell, 1980, 1988; Bernard and others, 1978). The degree of ${ }^{2} \mathrm{H}$ and ${ }^{13} \mathrm{C}$ fractionation between methane and its precursors (water $\left[\mathrm{H}_{2} \mathrm{O}\right]$ and $\mathrm{CO}_{2}$ ) has been used to identify pathways of microbial methanogenesis. In addition, the concentration of carbon-14 (the radioactive isotope of carbon) in methane has been used to estimate the relative age of the carbon precursor (Coleman and others, 1988, 1995). A major complication is that chemical and isotopic characteristics or "signatures" of methane can be altered by secondary processes such as mixing, migration, and oxidation, so interpretations of methane origin can be ambiguous, especially in regions with complex geologic histories.

\section{Conventional Gas Deposits}

Thermogenic methane is typically associated with commercial production of conventional hydrocarbons, which form by thermal maturation of organic-rich source beds (shales) in deep parts of sedimentary basins. After formation, hydrocarbons migrate updip and accumulate in a porous reservoir bed with a low permeability seal. Conventional hydrocarbons are typically extracted using traditional vertical wells with or without enhanced secondary stimulation. Thermogenic methane is most productive in deeper sections of a basin where organic matter is more thermally mature and has experienced more thermal cracking.

Heavier carbon and hydrogen isotopic signatures and lower concentrations of higher-chain hydrocarbons are related to a greater degree of thermal maturity, which generally increases with depth/age of the formation. As a result, chemical and isotopic characteristics of methane and higher-chain hydrocarbons have been used to unravel the complex history of hydrocarbon formation, migration, and mixing in the Appalachian Basin (Jenden and others, 1993; Laughrey and Baldassare, 1998; Burruss and Laughrey, 2010; Baldassare and others, 2014). In addition, gas composition and isotopes of methane and higher-chain hydrocarbons have been used to distinguish thermogenic gas from different geologic formations; for example, in northern West Virginia, the chemical and isotopic characteristics of methane in Upper Devonian bedrock is distinctly different from methane in Middle Devonian Marcellus Shale (Sharma and others, 2015).

\section{Unconventional Gas Deposits}

Shale gas and coal bed methane are considered to be unconventional gas resources because they form in situ and are extracted using horizontal drilling and hydraulic fracturing. Although conventional hydrocarbons are predominantly of thermogenic origin, unconventional gas deposits can be thermogenic, microbial, or mixed (Golding and others, 2013). Chemical and isotopic data have been used to investigate the origin of methane in parts of the Michigan Basin (Martini and others, 1998; McIntosh and others, 2002) and Illinois Basin (Coleman and others, 1988; McIntosh and others, 2002; Strapoc and others, 2007; Schegel and others, 2011). Commercial reserves of shale gas in Upper Devonian shale in northern Michigan are largely of microbial origin where the influx of meteoric water during or since Pleistocene glaciation created a favorable environment for microbial methanogenesis. In contrast, methane in Upper Devonian shale is of thermogenic origin near the center of the basin, where burial depths are greater and temperatures are higher (Martini and others, 1998)

Strapoc and others (2007) investigated commercial deposits of coal bed methane in Pennsylvanian-age bedrock along the eastern margin of the Illinois Basin, in Indiana and Kentucky. Chemical and isotopic data showed that methane 
was microbial in Indiana, where thermally immature bedrock is relatively shallow, and open to invasion of meteoric water through fractures. In contrast, methane is of thermogenic origin in Kentucky, where the formation was deeply buried in an area that had been more tectonically active.

Osborn and McIntosh (2010) documented isotopic and chemical characteristics of methane from Upper Devonian shales in the northern Appalachian Basin. Microbial methane was detected in shallow water wells along the margin of Lake Erie in northeastern Ohio, Pennsylvania, and New York. At depths greater than about $500 \mathrm{ft}$, methane was determined to be largely thermogenic but had evidence of some microbial activity.

\section{Methane in Water Wells}

Prior to shale gas development in the Appalachian Basin, a 2005 sampling effort examined methane in northern Pennsylvania water wells (Breen and others, 2007; Révész and others, 2012). Since the start of shale gas development in the Appalachian Basin, the occurrence and isotopic characteristics of methane in water wells has been investigated in parts of eastern Ohio (Botner, 2015), northeastern Pennsylvania (Osborn and others, 2011; Warner and others, 2012; Jackson and others, 2013; Molofsky and others, 2013; Darrah and others, 2015; Senior and others, 2016), New York (Heisig and Scott, 2013), and West Virginia (Chambers and others, 2015; Sharma and others, 2014; and Harkness and others, 2017).

Methane was analyzed in samples from 27 water wells that tap Pennsylvanian-age bedrock in eastern Ohio, and the origin was interpreted to be microbial or coal bed methane (Botner, 2015). Multiple studies have investigated the origin of methane in groundwater of northeastern Pennsylvania and (or) New York. Some investigators linked the presence of thermogenic methane to proximity to active shale gas wells (Osborn and others, 2011). Other investigators concluded that the presence of thermogenic methane was related to proximity to valleys, which are underlain by fractures that serve as natural pathways for migration of methane and (or) brine (Molofsky and others, 2013; Heisig and Scott, 2013).

The chemical and isotopic characteristics of methane in water wells of northern West Virginia have been documented by Sharma and others (2014), Chambers and others (2015), and Harkness and others (2017). A detailed investigation that included noble gas tracers in addition to methane isotopes determined that methane in groundwater is primarily microbial, with a ubiquitous, low proportion of thermogenic methane that migrated (along with saline water) along natural pathways (Harkness and others, 2017).

\section{Methods of Study}

For this study, groundwater samples were collected from 15 domestic wells known to produce methane. The Ohio Department of Natural Resources well log database was queried to select well logs that included "methane" or "gas" as part of the drillers' notes (Wayne Jones, Ohio Department of Natural Resources, written commun., 2016). The dataset included more than 1,000 wells, although a substantial number of wells were relatively old (pre-1970), could not be geographically located, or were abandoned after drilling because of an insufficient water supply. Some candidate wells also were identified through discussions with local health departments. Candidate sites were narrowed down by focusing on newer wells in a range of aquifers and geographic areas. An attempt was made to avoid sites near potential sources of methane related to human activities, but this proved to be impractical because potential sources of methane are ubiquitous.

\section{Sample Collection and Analysis}

Water samples were collected from domestic wells using existing submersible pumps. The wells were purged before sampling, and samples were collected from outside taps not connected to any form of water treatment. A summary of the methods used for collection and analysis of the samples is shown in table 1.

Unstable physical and chemical properties $(\mathrm{pH}$, specific conductance, water temperature, turbidity, dissolved oxygen, alkalinity, and hydrogen sulfide) were measured in the field, and samples for analysis of major ions, nutrients, trace elements, arsenic speciation, and dissolved organic carbon were analyzed at the USGS National Water Quality Laboratory. Methods used for sample collection and preservation are described in U.S. Geological Survey (variously dated).

Samples of dissolved gases and isotopes of methane, water, and dissolved inorganic carbon (DIC) were analyzed at Isotech Laboratories, Champaign, Ill. Samples for analysis of dissolved gases and isotopes of carbon and hydrogen in methane (including carbon-14) were collected in collapsible, preevacuated containers in which a benzalkonium chloride preservative capsule had been inserted (Isotech Laboratories, Inc., 2014). Samples for analysis of isotopes of hydrogen and oxygen in water and carbon in DIC were filtered using a 45-micron capsule filter and preserved by chilling (Keith Hackley, Isotech Laboratories, written commun., 2016).

Dissolved gases analyzed at the USGS Reston Groundwater Dating Laboratory were collected in septum vials and analyzed for nitrogen, carbon dioxide, oxygen, argon, and methane using methods described in U.S. Geological Survey (2016a, 2016b). 
Table 1. Methods used for collection and analysis of water-quality samples.

[USGS, U.S. Geological Survey; mg/L, milligram per liter; $\mu \mathrm{g} / \mathrm{L}$, microgram per liter; $\delta$, isotopic ratio delta notation]

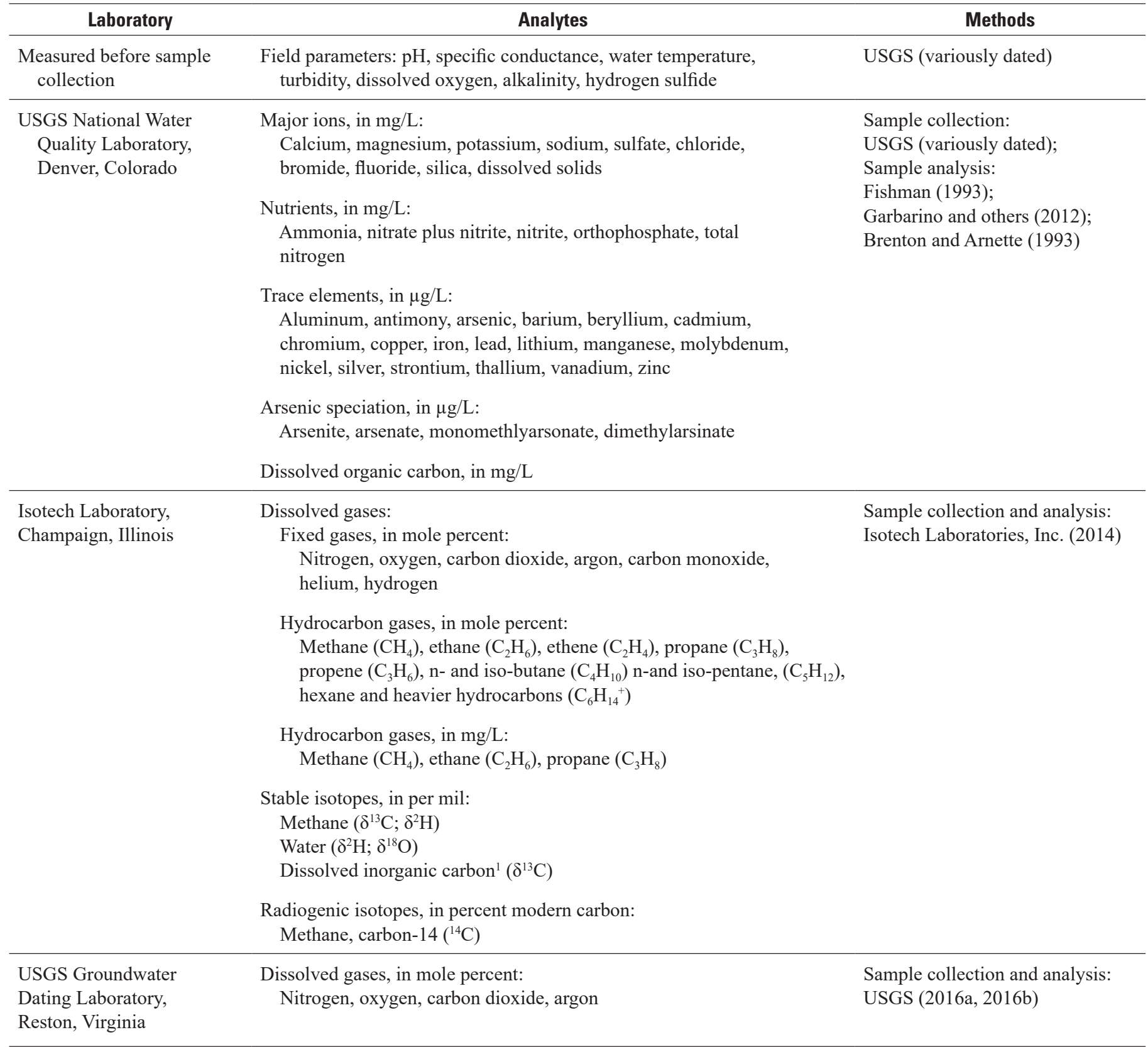

${ }^{1}$ Samples were unfiltered. 


\section{Quality Control}

Quality-control samples were analyzed to assess variability and bias of the water-quality data collected during this study. Quality-control samples were analyzed at the USGS National Water Quality Laboratory for major ions, trace elements, nutrients, arsenic speciation, and dissolved organic carbon (table 2, p. 34). Before the start of sampling, an equipment blank was collected and analyzed for trace elements to identify if the sampling equipment could be a source of bias. During the $2 \frac{1}{2}$ weeks of sample collection, two field blanks were collected to assess if field methods could be a source of bias. A total of three pairs of sequential replicates were collected to assess variability related to lab or field methods. The equipment and field blanks did not show detections of any of the constituents. For the replicate samples, the percent difference was calculated as the difference between concentrations for two samples divided by the mean concentration. Differences between replicate pairs were less than 15 percent for all constituents except for lithium (17 percent), dissolved organic carbon ( 38 percent) and zinc (57 percent). For lithium, the variability can be linked to small differences in low concentrations that were just above the reporting limits. For dissolved organic carbon and zinc, the cause of the variability is not known; however, it is not judged to be a substantial concern in relation to this investigation.

A total of two pairs of sequential replicates were analyzed for dissolved gases and isotopes of methane and water at Isotech Laboratories (table 3, p. 36). Differences between replicate pairs were less than 15 percent for all constituents, except for helium (17 percent), ${ }^{13} \mathrm{C}$ of DIC (27 percent), and propane (29 percent). For helium and propane, the variability can be linked to small differences in low concentrations that were just above reporting limits. For the carbon isotopic composition of DIC, the calculated variability may overstate the actual variability because the carbon isotopic composition of DIC spans negative and positive values.
One of the replicate pairs analyzed at Isotech Laboratories also was submitted to the USGS Reston Groundwater Dating Laboratory to assess analytical differences between the two laboratories. The samples were analyzed for methane, oxygen, nitrogen, carbon dioxide, and argon. The results revealed substantial differences between the labs (from 29 percent to more than 190 percent), which are likely related to substantial differences in methods used for sample collection, preservation and holding times, and lab analysis (table 1). Another factor that likely affected the variability is that the replicate sample was from the well with the maximum methane concentration $(120 \mathrm{mg} / \mathrm{L}$ as determined by Isotech Laboratories). The sample collection method recommended by Isotech Laboratories prevents methane loss from degassing better than the method recommended by the USGS Groundwater Dating Laboratory (Molofsky and others, 2013).

\section{Isotopic Nomenclature}

Isotopic ratios represent the relative difference in the ratio of the less abundant isotope to the more abundant isotope $(R)$ with respect to a standard. Isotopic data are expressed in parts per thousand (per mil or \%o) using standard $\delta$ notation (Clark and Fritz, 1997):

$$
\delta_{\text {sample }}=\left(\left[R_{\text {sample }}-R_{\text {standard }}\right] / R_{\text {standard }}\right) * 1,000
$$

A sample that is enriched in the heavy isotope relative to the standard has a positive $\delta$ value, and a sample that is depleted in the heavy isotope relative to the standard has a negative $\delta$ value.

For stable carbon isotopes, $R$ is ${ }^{13} \mathrm{C} /{ }^{12} \mathrm{C}$, and the standard is Vienna Peedee belemnite (Clark and Fritz, 1997). For stable hydrogen isotopes, $R$ is ${ }^{2} \mathrm{H} /{ }^{1} \mathrm{H}$, and the standard is Vienna Standard Mean Ocean Water. For stable oxygen isotopes, $R$ is ${ }^{18} \mathrm{O} /{ }^{16} \mathrm{O}$, and the standard is Vienna Standard Mean Ocean Water (Clark and Fritz, 1997). 


\section{Characteristics of the Well Network}

The 15 wells sampled for this study produce water and methane from a range of aquifer types, including Pleistocene glacial deposits and four bedrock units: Pennsylvanian shale, sandstone, siltstone limestone, and coal; Lower Mississippian shale and sandstone; Upper Devonian organic-rich shale (also referred to as black shale); and Upper Ordovician shale and limestone (table 4). The unconsolidated deposits that overlie bedrock are predominantly glacial clay, and range in thickness from 4 to more than $171 \mathrm{ft}$. A similarity among the 15 wells is that the bedrock is predominantly shale and the glacial deposits are predominantly clay.

The wells are 75-345 ft deep, with a median depth of about $171 \mathrm{ft}$. The water levels were 9.75 to $85.86 \mathrm{ft}$ below land surface (BLS). The depth to the top of the open interval ranges from 31 to $190 \mathrm{ft}$ BLS. In general, construction characteristics of the wells in eastern Ohio differed from those in western Ohio. The nine bedrock wells in eastern Ohio are constructed as open holes and produce water from relatively long open intervals (15 to $302 \mathrm{ft}$ ). Of the six wells in western Ohio, one bedrock well has an open interval of $254 \mathrm{ft}$, but the other five wells produce from well screens that are relatively short (3-13 ft).

Table 4. Characteristics of Ohio domestic wells sampled for methane, 2016.

[ft, feet; BLS, below land surface; >, greater than]

\begin{tabular}{|c|c|c|c|c|}
\hline $\begin{array}{l}\text { Well } \\
\text { identifier }\end{array}$ & $\begin{array}{c}\text { Well } \\
\text { depth } \\
\text { (ft BLS) }\end{array}$ & $\begin{array}{l}\text { Lithology and } \\
\text { thickness (ft) } \\
\text { of glacial deposits }\end{array}$ & $\begin{array}{c}\text { Type of open } \\
\text { interval; depths of } \\
\text { open interval (ft) }\end{array}$ & Lithology; drillers notation of gas \\
\hline \multicolumn{5}{|c|}{ Pennsylvanian shale, sandstone, siltstone, limestone, coal } \\
\hline ST-139 & 235 & $\begin{array}{c}\text { Clay/sand/gravel } \\
160\end{array}$ & $\begin{array}{l}\text { Open hole } \\
190-235\end{array}$ & Shale overlain by $160-\mathrm{ft}$ glacial deposits. \\
\hline ST-140 & 295 & $\begin{array}{l}\text { Clay/sand } \\
10\end{array}$ & $\begin{array}{l}\text { Open hole } \\
149-295\end{array}$ & Interbedded sandstone/sandy shale with thin coal and limestone. \\
\hline ST-141 & 301 & $\begin{array}{c}\text { Clay } \\
24\end{array}$ & $\begin{array}{l}\text { Open hole } \\
69-301\end{array}$ & Interbedded shale/sandstone with thin coal and limestone. \\
\hline $\mathrm{CO}-31$ & 345 & $\begin{array}{c}\text { Clay } \\
15\end{array}$ & $\begin{array}{l}\text { Open hole } \\
43-345\end{array}$ & $\begin{array}{l}\text { Interbedded shale/sandstone with black limestone and shale. } \\
\text { Gas at } 280 \mathrm{ft} \text { (black/gray shale). }\end{array}$ \\
\hline MU-128 & 263 & $\begin{array}{c}\text { Clay } \\
50\end{array}$ & $\begin{array}{l}\text { Open hole } \\
51-263\end{array}$ & $\begin{array}{l}\text { Interbedded shale/sandstone with thin coal. Gas at } 131 \mathrm{ft} \\
\text { (sandstone above thin coal). }\end{array}$ \\
\hline \multicolumn{5}{|c|}{ Lower Mississippian shale and sandstone } \\
\hline GE-368 & 150 & $\begin{array}{l}\text { Clay and sand } \\
32\end{array}$ & $\begin{array}{l}\text { Open hole } \\
40-150\end{array}$ & Shale and sandstone. Gas at $118 \mathrm{ft}$ (shale). \\
\hline SU-23 & 95 & $\begin{array}{l}\text { Clay; sand/gravel } \\
75\end{array}$ & $\begin{array}{l}\text { Open hole } \\
\quad 80-95\end{array}$ & Shale. Gas at $75 \mathrm{ft}$ (interface of glacial deposits and shale). \\
\hline PE-59 & 190 & $\begin{array}{c}\text { Loam } \\
\quad 4\end{array}$ & $\begin{array}{c}\text { Open hole } \\
169-190\end{array}$ & Sandstone and shale. \\
\hline \multicolumn{5}{|c|}{ Upper Devonian black shale; glacial deposits } \\
\hline DE-29 & 144 & $\begin{array}{c}\text { Clay/gravel/hardpan } \\
>144\end{array}$ & $\begin{array}{c}\text { Well screen } \\
141-144\end{array}$ & $\begin{array}{l}144 \mathrm{ft} \text { of glacial deposits overlying Upper Devonian shale. Gas at } 93 \mathrm{ft} \\
\text { (thin sand within clay). }\end{array}$ \\
\hline \multicolumn{5}{|c|}{ Upper Ordovician shale and limestone; glacial deposits } \\
\hline GR-755 & 171 & $\begin{array}{l}\text { Clay } \\
>171\end{array}$ & $\begin{array}{l}\text { Well screen } \\
168-171\end{array}$ & $\begin{array}{l}171 \mathrm{ft} \text { of clay valley fill overlying Ordovician limestone/shale bedrock. } \\
\text { Gas at } 165 \mathrm{ft} \text { (clay above open interval). }\end{array}$ \\
\hline MT-1286 & 300 & Clay 36 & $\begin{array}{l}\text { Open hole } \\
46-300\end{array}$ & Limestone with shale at base. Gas at $293 \mathrm{ft}$ (shale). \\
\hline
\end{tabular}




\section{Groundwater Quality}

Water samples from the well network were analyzed for field parameters; major ions; trace elements; nutrients; dissolved organic carbon; dissolved gases; stable isotopes of water, methane, DIC; and the radioactive carbon isotope of methane (table 1). The water-quality dataset is presented in table 5 (p. 37) and is accessible on the National Water Information System web interface (U.S. Geological Survey, 2018).

\section{Dissolved Gases and Methane Concentrations}

Headspace gases of water samples were analyzed for nitrogen, carbon dioxide, oxygen, argon, carbon monoxide, hydrogen, helium, methane, and higher-chain hydrocarbons (ethane, ethene, propane, propene, n-butane, iso-butane, n-pentane, iso-pentane, and hexanes ${ }^{+}$) (table 1). Dissolved gas in groundwater exists under pressure, and as the water is pumped to the land surface, the pressure drops and dissolved gases come out of solution. Different gases come out of solution at different rates, so the composition of headspace gases does not necessarily represent equilibrium between the gas and water at subsurface formation pressures and temperatures (Coleman and others, 1988).
The composition of gas in each sample is shown in figure 4. (Only gases that make up more than 1 mole percent are shown on the plot.) The predominant gases were methane (5.46-93.31 mole percent) and nitrogen (3.87-70.77 mole percent). Concentrations of nitrogen and methane are nearly inversely related; methane was the dominant component in 13 samples, and nitrogen was the dominant component in 2 of 15 samples. At least one or more higher-chain hydrocarbons were detected in all samples. Ethane $\left(\mathrm{C}_{2}\right)$ was detected in all 15 samples (0.0029-12.42 mole percent), propane $\left(\mathrm{C}_{3}\right)$ was detected in 5 samples (0.0001-2.49 mole percent), and hydrocarbons heavier than propane $\left(\mathrm{C}_{4+}\right)$ were detected in 3 samples (0.0006-0.2510 mole percent). One sample (SU23) had concentrations of higher-chain hydrocarbons that totaled 15.47 mole percent. For the other 14 samples, the total concentration of higher-chain hydrocarbons was 0.0029 to 0.3066 mole percent.

Concentrations of methane, in units of milligrams per liter, ranged from 1.2 to $120 \mathrm{mg} / \mathrm{L}$ (fig. 5). Twelve of the wells had methane concentrations greater than $28 \mathrm{mg} / \mathrm{L}$, which is the approximate solubility of methane in water at atmospheric pressure. There is no regulatory level for methane in water; however, the U.S. Office of Surface Mining recommends that wells be vented if methane concentrations in well water exceed $28 \mathrm{mg} / \mathrm{L}$ (Eltschlager and others, 2001).
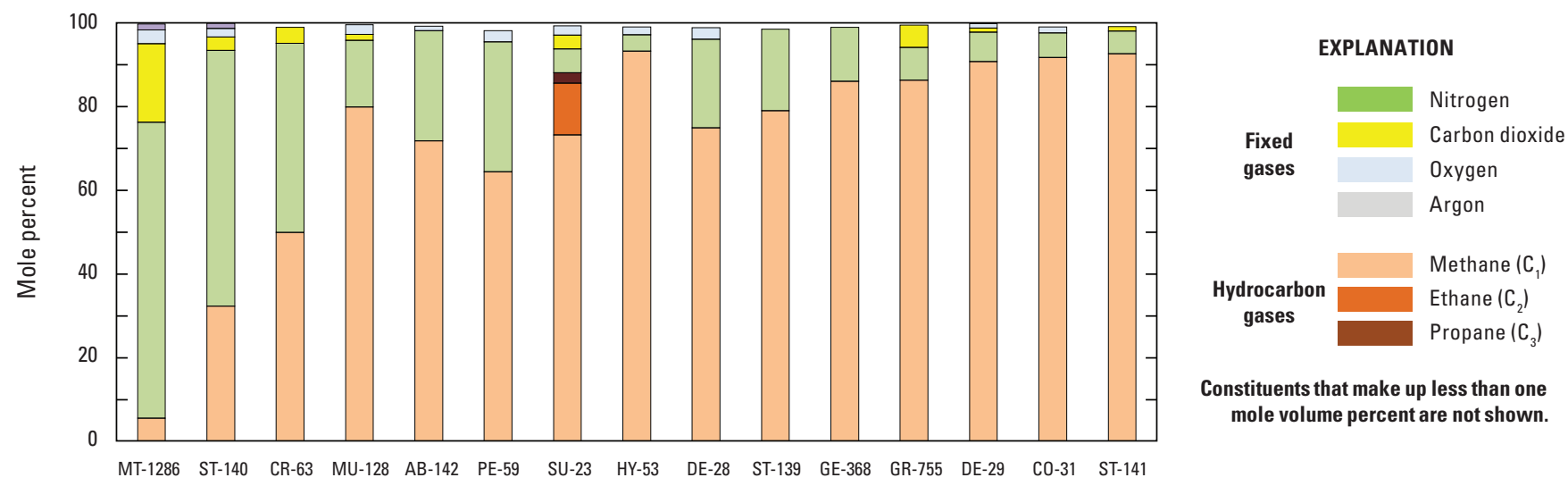

Figure 4. Composition of headspace gases in water samples from domestic wells in Ohio, 2016.

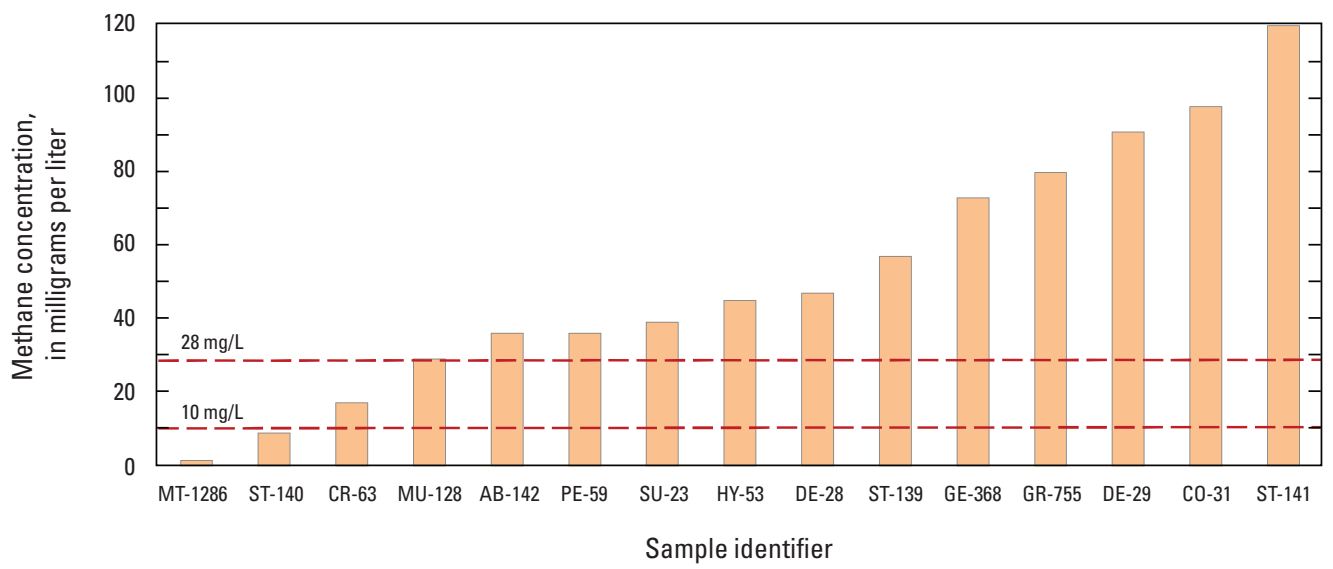

EXPLANATION

Recommended action levels for methane in water (Eltschlager and others, 2001)

Greater than 28 milligrams per liter: Immediate venting of the well head to the atmosphere; further modification of the water system may be needed.

10-28 milligrams per liter: Provide warning related to venting of the well head and removal of ignition sources.

Less than 10 milligrams per liter: Periodic monitoring is recommended.

Figure 5. Methane concentrations in water samples from domestic wells in Ohio, 2016. 


\section{Dissolved Inorganic Constituents}

A wide range of water-quality conditions exist in the wells sampled for this study (table 6). The $\mathrm{pH}$ of water samples ranged from 7.0 to 9.0 ; alkalinity ranged from 225 to $889 \mathrm{mg} / \mathrm{L}$ as $\mathrm{CaCO}_{3}$; dissolved solids ranged from 318 to $2,940 \mathrm{mg} / \mathrm{L}$; and chloride ranged from 7.04 to $1,350 \mathrm{mg} / \mathrm{L}$. Water types ranged from $\mathrm{CaMgHCO}_{3}$ (generally characteristic of shallow, recently recharged water) to $\mathrm{NaCl}$ (generally characteristic of deeper, older waters). The most common water type, detected in five wells, was $\mathrm{NaHCO}_{3}$. This water type can be associated with intermediate to deeper parts of groundwater systems in which $\mathrm{Na}$ is derived from cation exchange with clay minerals and (or) mixing with $\mathrm{NaCl}$ waters, and $\mathrm{HCO}_{3}$ is derived from dissolution of carbonate minerals and (or) microbial oxidation of organic matter (Hem, 1992; Back, 1966).

Methane is not expected to coexist with electron acceptors such as dissolved oxygen (DO), nitrate $\left(\mathrm{NO}_{3}\right)$, or sulfate $\left(\mathrm{SO}_{4}\right)$; however, 1 or more of these constituents were detected in 6 samples (table 6). Detection of these electron acceptors in the presence of methane may indicate that the samples are a mix of water from multiple horizons with different redox conditions. Of the six samples with detections of $\mathrm{DO}, \mathrm{NO}_{3}$, and (or) $\mathrm{SO}_{4}$, five were from wells with relatively shallow open intervals (less than $50 \mathrm{ft}$ BLS).

Table 6. Methane concentrations and selected water-quality constituents from Ohio domestic wells, 2016.

$\left[\mathrm{mg} / \mathrm{L}\right.$, milligrams per liter; $\mathrm{CaCO}_{3}$, calcium carbonate; $\mathrm{DO}$, dissolved oxygen; $\mathrm{NO}_{3}$, nitrate; $\mathrm{SO}_{4}$, sulfate; $\mathrm{Na}$, sodium; $\mathrm{Cl}$, chloride; <, less than; $\mathrm{Ca}$, calcium; $\mathrm{HCO}_{3}$, bicarbonate; $\mathrm{Mg}$, magnesium; $\mathrm{H}$, hydrogen]

\begin{tabular}{|c|c|c|c|c|c|c|c|c|c|}
\hline \multirow{2}{*}{$\begin{array}{c}\text { Well } \\
\text { identifier }\end{array}$} & \multirow{2}{*}{$\begin{array}{c}\text { Methane } \\
\text { (mg/L) }\end{array}$} & \multirow{2}{*}{ Water type } & \multirow{2}{*}{$\begin{array}{c}\text { Dissolved } \\
\text { solids } \\
\text { (mg/L) }\end{array}$} & \multirow{2}{*}{$\begin{array}{c}\mathrm{pH} \\
\text { (standard } \\
\text { units) }\end{array}$} & \multirow{2}{*}{$\begin{array}{c}\text { Alkalinity } \\
\text { (mg/L as } \\
\mathrm{CaCO}_{3} \text { ) }\end{array}$} & \multirow{2}{*}{$\begin{array}{c}\text { Chloride } \\
\text { (mg/L) }\end{array}$} & \multicolumn{3}{|c|}{ Electron acceptors, in $\mathrm{mg} / \mathrm{L}$} \\
\hline & & & & & & & DO & $\mathrm{NO}_{3}$ & $\mathrm{SO}_{4}$ \\
\hline \multicolumn{10}{|c|}{ Pennsylvanian shale, sandstone, siltstone, limestone, coal } \\
\hline ST-139 & 57 & $\mathrm{NaSO}_{4} \mathrm{Cl}$ & 1,120 & 8.2 & 454 & 727 & 0.2 & $<0.040$ & 594 \\
\hline ST-140 & 8.7 & $\mathrm{CaNaHCO}_{3}$ & 352 & 7.5 & 278 & 17.8 & 0.2 & $<0.040$ & 0.03 \\
\hline MU-128 & 29 & $\mathrm{NaHCO}_{3}$ & 754 & 8.1 & 452 & 140 & 0.2 & $<0.040$ & 0.11 \\
\hline \multicolumn{10}{|c|}{ Lower Mississippian shale and sandstone } \\
\hline AB-142 & 36 & $\mathrm{NaHCO}_{3}$ & 466 & 8.7 & 375 & 13.1 & 1.2 & $<0.040$ & 0.24 \\
\hline GE-368 & 73 & $\mathrm{NaHCO}_{3}$ & 645 & 9.0 & 320 & 60.8 & 0.2 & $<0.040$ & 3.56 \\
\hline \multicolumn{10}{|c|}{ Upper Devonian black shale; glacial deposits } \\
\hline DE-29 & 91 & $\mathrm{CaNaHCO}_{3}$ & 387 & 7.5 & 278 & 40.7 & 0.2 & $<0.040$ & 0.07 \\
\hline HY-53 & 45 & $\mathrm{CaNaHCO}_{3}$ & 421 & 7.9 & 252 & 80.8 & 0.2 & $<0.040$ & 0.07 \\
\hline DE-28 & 47 & $\mathrm{CaNaHCO}_{3}$ & 318 & 7.7 & 225 & 32.2 & 0.3 & $<0.040$ & 0.06 \\
\hline CR-63 & 17 & $\mathrm{CaMgNaHCO}_{3} \mathrm{SO}_{4}$ & 619 & 7.4 & 339 & 7.04 & 0.2 & $<0.040$ & 233 \\
\hline \multicolumn{10}{|c|}{ Upper Ordovician shale and limestone; glacial deposits } \\
\hline GR-755 & 80 & $\mathrm{CaMgNaHCO}_{3}$ & 716 & 7.1 & 581 & 74.9 & 0.2 & $<0.040$ & 0.25 \\
\hline MT-1286 & 1.2 & $\mathrm{CaMgHCO}_{3}$ & 479 & 7 & 393 & 29.1 & 0.2 & 0.298 & 26 \\
\hline
\end{tabular}




\section{Stable Isotopes of Water}

The isotopic composition of water $\left(\delta^{18} \mathrm{O}_{\mathrm{H} 2 \mathrm{O}}, \delta^{2} \mathrm{H}_{\mathrm{H} 2 \mathrm{O}}\right)$ can provide information about its origin. Water undergoes isotopic fractionation when it falls as precipitation, and the isotopic characteristics are generally retained when precipitation recharges the groundwater system. Groundwater that originated as precipitation has characteristic ratios of $\delta^{2} \mathrm{H}_{\mathrm{H} 2 \mathrm{O}}$ and $\delta^{18} \mathrm{O}_{\mathrm{H} 2 \mathrm{O}}$ that generally plot along the Global Meteoric Water Line (GMWL) (Craig, 1961). Isotopic fractionation is greater at cooler temperatures, so water recharged in cooler climates will have lighter isotopic ratios than water recharged in warmer climates. Deep-basin brines generally plot to the right of the GMWL as a result of evaporative concentration and (or) interaction with aquifer solids.

Samples from domestic wells had $\delta^{18} \mathrm{O}_{\mathrm{H} 2 \mathrm{O}}$ of -16.05 to -7.15 per mil and $\delta^{2} \mathrm{H}_{\mathrm{H} 2 \mathrm{O}}$ of -114.6 to -47.1 per mil (fig. 6). The samples generally fall along the GMWL, consistent with water that originated as precipitation. Also shown in figure 6 is the range of isotopic ratios of water from Ohio rivers (Kendall and Coplen, 2001). Of 15 samples, 12 have values within this range, consistent with precipitation of the present-day climate.

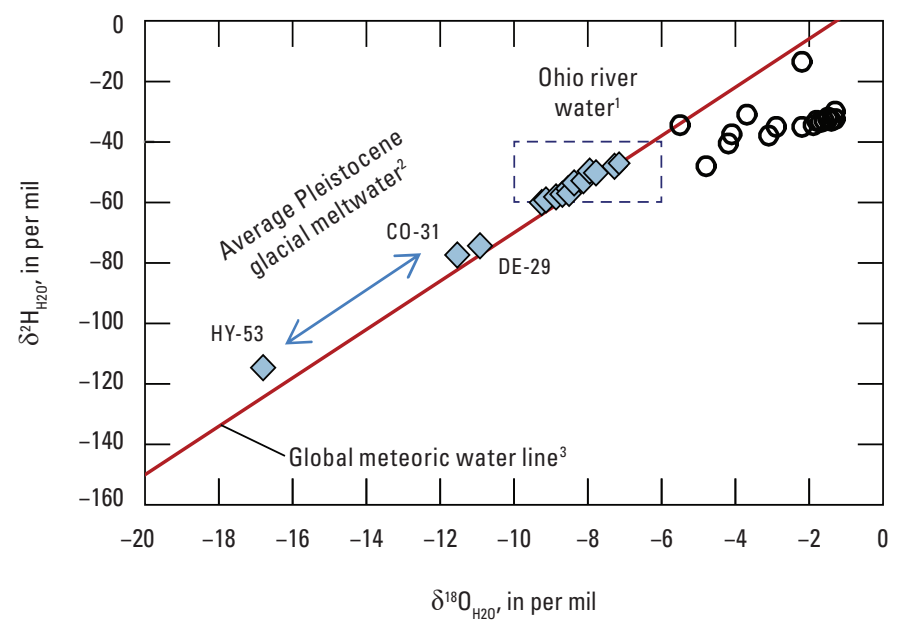

On the other hand, 3 of 15 samples have lighter isotopic ratios, similar to average recharge during Pleistocene glaciation, when temperatures were cooler (Martini and others, 1998; McIntosh and others, 2002). None of the samples had isotopic signatures similar to brines of eastern Ohio (Breen and others, 1985).

The occurrence of isotopically light $\mathrm{H}_{2} \mathrm{O}$ in three samples indicates that bedrock formations in parts of Ohio have not been fully flushed by modern or postglacial recharge. Of the three samples with isotopically light $\mathrm{H}_{2} \mathrm{O}$, two (DE-29 and HY-53) are from the northwestern corner of Ohio, where a thick layer of glacial lakebed clay overlies Upper Devonian black (organic-rich) shales. Other investigators (Eberts and George, 2000; Churchill, 2000) also detected isotopically light groundwaters in the northwestern corner of Ohio and concluded that the lakebed clays inhibited the recharge of postglacial waters. The third sample with isotopically light $\mathrm{H}_{2} \mathrm{O}(\mathrm{CO}-31)$ is from the deepest well sampled for the study $(345 \mathrm{ft})$, in eastern Ohio. In later figures, the 3 samples with $\mathrm{H}_{2} \mathrm{O}$ isotopes indicative of glacial recharge are shown as dark blue diamonds, and the 12 samples with $\mathrm{H}_{2} \mathrm{O}$ isotopes indicative of modern or postglacial recharge are shown as light blue diamonds.

Figure 6. Stable isotopes of water from domestic wells in Ohio, 2016. 


\section{Chemical and Isotopic Characteristics of Methane and Related Constituents}

The origin of methane can be evaluated using selected chemical and isotopic characteristics of methane and related constituents. The following section describes information about methane origin based on stable isotopes of methane, gas dryness, and isotopic fractionation between methane and its microbial precursors $-\mathrm{H}_{2} \mathrm{O}$ and $\mathrm{CO}_{2}$.

\section{Stable Isotopes of Methane}

Stable isotopes of methane $\left(\delta^{13} \mathrm{C}_{\mathrm{CH} 4}, \delta^{2} \mathrm{H}_{\mathrm{CH} 4}\right)$ have been used to differentiate thermogenic and microbial methane (Schoell, 1980, 1988; Whiticar and others, 1986; Whiticar, 1999). In part, microbial methane is isotopically lighter than thermogenic methane because microbes preferentially utilize lighter isotopes, which have lighter bonds that are easier to break. The isotopic signature of thermogenic methane is related to thermal maturity, which generally increases with age/depth of the source rock. In general, $\delta^{13} \mathrm{C}_{\mathrm{CH} 4}$ greater than -45 to -50 per mil is considered to be diagnostic of thermogenic methane, and $\delta^{13} \mathrm{C}_{\mathrm{CH} 4}$ less than about -60 or -55 per mil is considered to be diagnostic of microbial methane (Schoell, 1980, 1988; Whiticar and others, 1986; Whiticar, 1999). However, $\delta^{13} \mathrm{C}_{\mathrm{CH} 4}$ ranges for thermogenic and microbial methane can overlap; for example, microbial methane formed in a closed system can have $\delta^{13} \mathrm{C}_{\mathrm{CH} 4}$ as high as -31 per mil (Martini and others, 2003).

Samples from domestic wells had $\delta^{13} \mathrm{C}_{\mathrm{CH} 4}$ of -75.19 to -47.7 per mil and $\delta^{2} \mathrm{H}_{\mathrm{CH} 4}$ of -285.7 to -206 per mil. On a Whiticar plot (Whiticar and others, 1986), 12 of 15 samples plot in the fields for microbial methane, 1 sample plots in the field for thermogenic methane, and 2 samples plot in between, in areas of mixing or transition (fig. 7A). The field for microbial methane is subdivided into fields for acetate fermentation and $\mathrm{CO}_{2}$ reduction; however, identifying pathways of microbial methanogenesis based on Whiticar plot alone can be misleading for study areas with isotopically light $\mathrm{H}_{2} \mathrm{O}$ (Golding and others, 2013; Vinson and others, 2017). Therefore, differentiating pathways of microbial methanogenesis will be discussed in a later section of this report ("Isotopic Characteristics of Microbial Methane").

For comparison, samples of methane from commercial hydrocarbon wells in eastern Ohio had $\delta^{13} \mathrm{C}_{\mathrm{CH} 4}$ of -53 to -37 per mil and $\delta^{2} \mathrm{H}_{\mathrm{CH} 4}$ of -315 to -150 per mil (Laughrey and Baldassare 1998; Barton and others, 1998; Burruss and Laughrey, 2010; and Osborn and McIntosh, 2010). On the Whiticar plot (fig. $7 A$ ), these samples plot along a linear trend; the lightest isotopic compositions are in the youngest formations (Upper Devonian shales) at the shallowest depths (550-1,200 ft), and the heaviest isotopic compositions are in the oldest formations (Upper Cambrian/Ordovician bedrock) at the greatest depths $(7,000-8,500 \mathrm{ft})$.
Secondary processes such as mixing, migration, and oxidation can alter original isotopic signatures and lead to ambiguity in interpreting methane origin based on stable isotopes of methane. Mixing should create gas of an intermediate composition that lies along a mixing line between the endmembers. Increases in $\delta^{13} \mathrm{C}_{\mathrm{CH} 4}$ and $\delta^{2} \mathrm{H}_{\mathrm{CH} 4}$ can be caused by oxidation of microbial methane or mixing of microbial and thermogenic methane (Schoell, 1988).

\section{Gas Dryness}

The ratio of methane to the sum of ethane and propane $\left(\mathrm{C}_{1} /\left(\mathrm{C}_{2}+\mathrm{C}_{3}\right)\right)$ is referred to as gas dryness (Bernard and others, 1978; Golding and others, 2013). Thermogenic gas typically includes substantial concentrations of higherchain hydrocarbons because it forms by thermal cracking of complex organic compounds into successively simpler molecules, the simplest of which is methane. With increasing thermal maturity, gas dryness increases as additional higherchain hydrocarbons are cracked. On the other hand, microbial gas is predominantly methane, with minor amounts of ethane and propane (Bernard and others, 1978). In general, dryness values greater than about 1,000 are considered to be diagnostic for microbial origin, and values less than 100 are considered to be diagnostic for thermogenic methane (Bernard and others, 1978; Golding and others, 2013).

A Bernard plot shows $\delta^{13} \mathrm{C}_{\mathrm{CH} 4}$ in relation to dryness (fig. 7B) (Bernard and others, 1978). Thermogenic methane plots in the lower right corner of the graph because it is isotopically heavier and includes a substantial proportion of higher-chain hydrocarbons (low dryness). Microbial methane plots in the upper left corner of the graph because it is isotopically lighter, with only minor amounts of higherchain hydrocarbons (increased dryness). Samples from domestic wells had dryness values of 5-29,772. Of the 15 samples, 1 plots in the thermogenic field, 11 plot within the microbial field, and 3 plot in between (fig. $7 B$ ). For comparison, gas samples from commercial hydrocarbon wells in eastern Ohio had dryness values of 4-16, consistent with thermogenic methane (Laughrey and Baldassare, 1998; Barton and others, 1998; Burruss and Laughrey, 2010; and Osborn and McIntosh, 2010).

Secondary processes (mixing, migration, or oxidation) can shift $\delta^{13} \mathrm{C}_{\mathrm{CH} 4}$ and (or) $\mathrm{C}_{1} /\left(\mathrm{C}_{2}+\mathrm{C}_{3}\right)$, as shown by arrows on figure $7 \mathrm{~B}$. Mixing should create gas of an intermediate composition that lies along a mixing line between the endmembers. Microbial oxidation of methane should cause an increase in $\delta^{13} \mathrm{C}_{\mathrm{CH} 4}$ (because lighter isotopes are preferentially removed by microbes) and a decrease in dryness (because methane is oxidized more readily than higher-chain hydrocarbons) (Whiticar and others, 1986; Sharma and others, 2014). Migration (or diffusion) of thermogenic methane should cause an increase in dryness because lighter hydrocarbons should migrate more readily than heavier hydrocarbons (Schoell, 1980, 1988; Martini and others, 1998). 
Thermal maturation of thermogenic gas should also increase dryness, as complex organic molecules are progressively cracked to methane. Several processes can cause an increase in $\delta^{13} \mathrm{C}_{\mathrm{CH} 4}$, including mixing microbial methane with thermogenic methane, oxidation of methane by microbial processes, and Rayleigh-type fractionation in a partially closed system (oxidation of methane and Rayleigh-type fractionation will be discussed in later sections of this report).

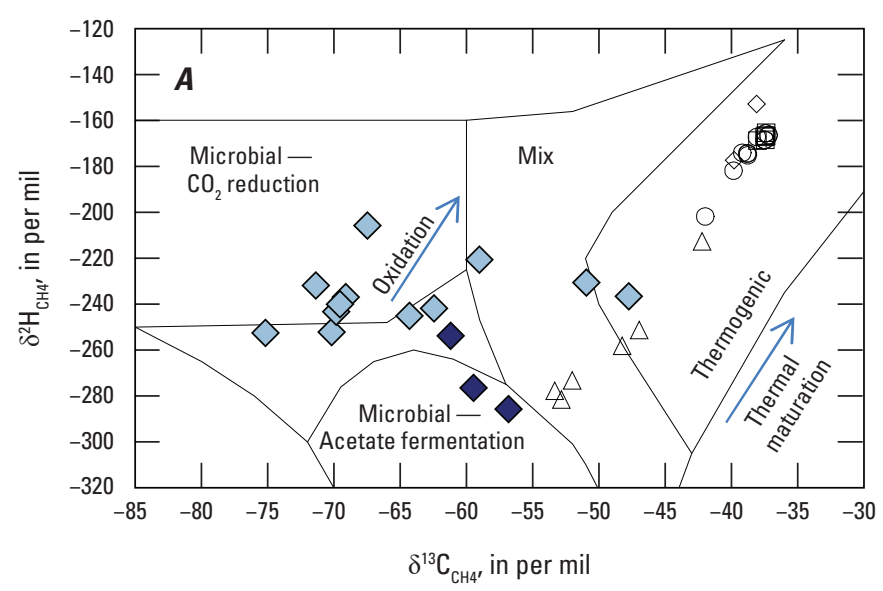

After Whticar and others (1986)

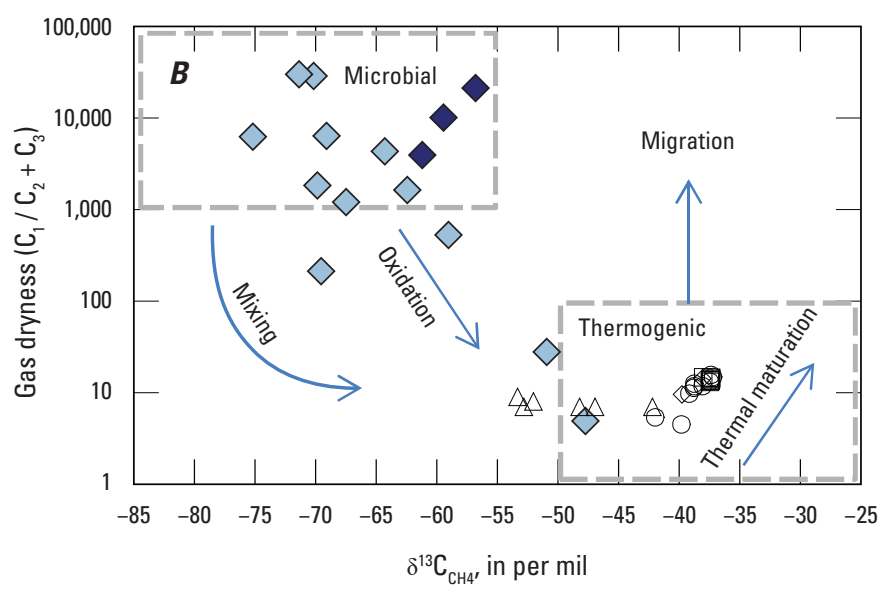

After Bernard and others (1978)
A broad interpretation of the Whiticar plot (fig. $7 A$ ) and the Bernard plot (fig. $7 B$ ) is that 13 samples can be interpreted as predominantly microbial, and 2 samples (SU-23 and MT-1286) can be interpreted as having a component of thermogenic methane. On figures 8 and 9, red dots are used to represent the two samples with a component of thermogenic methane.

\section{EXPLANATION}

Samples from domestic wells sampled for this study

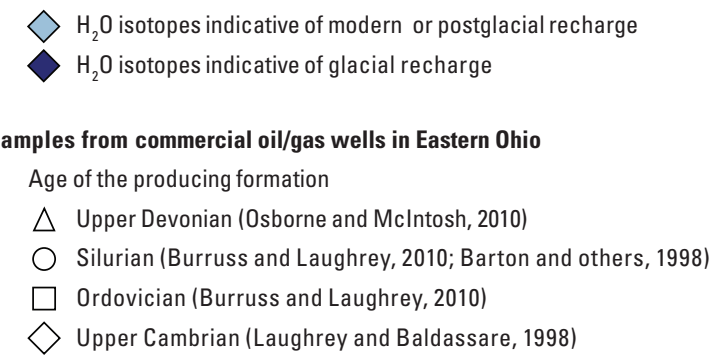

Samples from commercial oil/gas wells in Eastern Ohio Age of the producing formation

$\triangle$ Upper Devonian (Osborne and McIntosh, 2010)

Silurian (Burruss and Laughrey, 2010; Barton and others, 1998)

$\diamond$ Upper Cambrian (Laughrey and Baldassare, 1998)

Figure 7. Gas classification diagrams showing samples from domestic wells in Ohio. $A$, Whiticar plot. $B$, Bernard plot. 


\section{Isotopic Characteristics of Microbial Methane}

Microbial methane forms during the final stages of decomposition of organic matter in anaerobic environments. Conditions favorable for microbial methanogenesis include low temperatures and salinities; lack of other electron acceptors such as $\mathrm{O}_{2}, \mathrm{NO}_{3}$, and $\mathrm{SO}_{4}$; and the presence of microbial communities capable of breaking down complex organic matter into compounds methanogens can utilize.

The isotopic composition of microbial methane is related to $\delta^{13} \mathrm{C}$ of the organic precursor, $\delta^{2} \mathrm{H}$ of coexisting water, and the predominant microbial process (pathway) that created the methane. There are two primary pathways of microbial methanogenesis - acetate fermentation and $\mathrm{CO}_{2}$ reduction. In general, acetate fermentation is associated with younger, fresher organic matter and warmer temperatures in near-surface environments, such as marshes, wetlands, landfills, and sewers (Schoell, 1988). Acetate fermentation is represented by the following simplified equation:

$$
\mathrm{CH}_{3} \mathrm{COOH} \rightarrow \mathrm{CH}_{4}+\mathrm{CO}_{2}
$$

$\mathrm{CO}_{2}$ reduction is associated with older organic matter and cooler temperatures in the subsurface and is the predominant pathway associated with groundwater systems, marine sediments, and relatively shallow deposits of microbial shale gas and coal bed methane (Schoell, 1988; Whiticar, 1999; Martini and others, 1998). $\mathrm{CO}_{2}$ reduction is represented by the following simplified equation:

$$
\mathrm{CO}_{2}+4 \mathrm{H}_{2} \rightarrow \mathrm{CH}_{4}+2 \mathrm{H}_{2} \mathrm{O}
$$

The two pathways result in different degrees of carbon and hydrogen isotope fractionation; methane formed by $\mathrm{CO}_{2}$ reduction is typically depleted in $\delta^{13} \mathrm{C}_{\mathrm{CH} 4}$ and enriched in $\delta^{2} \mathrm{H}_{\mathrm{CH} 4}$, as compared to methane formed by acetate fermentation.

where $\mathrm{CH}_{3} \mathrm{COOH}$ is acetate. 


\section{Fractionation of Hydrogen Isotopes}

For microbial methane, $\delta^{2} \mathrm{H}_{\mathrm{CH} 4}$ is related to $\delta^{2} \mathrm{H}_{\mathrm{H} 2 \mathrm{O}}$ of the coexisting water and the microbial pathway. If the isotopic characteristics of water are known, the difference between $\delta^{2} \mathrm{H}_{\mathrm{H} 2 \mathrm{O}}$ and $\delta^{2} \mathrm{H}_{\mathrm{CH} 4}$ can provide evidence about the pathway of microbial methanogenesis.

For the $\mathrm{CO}_{2}$ reduction pathway, all the $\mathrm{H}$ in $\mathrm{CH}_{4}$ is derived from coexisting water and $\delta^{2} \mathrm{H}_{\mathrm{H} 2 \mathrm{O}}$ and $\delta^{2} \mathrm{H}_{\mathrm{CH} 4}$ are expected to follow the equation below (Schoell, 1980; Whiticar and others, 1986):

$$
\delta^{2} \mathrm{H}_{\mathrm{CH} 4}=\delta^{2} \mathrm{H}_{\mathrm{H} 2 \mathrm{O}}-160( \pm 10 \%)
$$

For the acetate fermentation pathway, hydrogen is derived from water and acetate. $\mathrm{H}$ in acetate is isotopically lighter than $\mathrm{H}$ in water because acetate is an organic compound formed by microbial processes that favor lighter isotopes. As a result, methane formed by acetate fermentation shows a greater degree of $\mathrm{H}$ fractionation than methane formed by $\mathrm{CO}_{2}$ reduction. The relation between methane and coexisting water is less well known for acetate fermentation than for $\mathrm{CO}_{2}$ reduction; the following equation was proposed for shallow freshwater systems where $\mathrm{SO}_{4}$ concentrations are low (Waldron and others, 1999; Golding and others, 2013):

$$
\delta^{2} \mathrm{H}_{\mathrm{CH} 4}=0.675 * \delta^{2} \mathrm{H}_{\mathrm{H} 2 \mathrm{O}}-284( \pm 6 \% \text { o })
$$

In figure $8, \delta^{2} \mathrm{H}_{\mathrm{H} 2 \mathrm{O}}$ and $\delta^{2} \mathrm{H}_{\mathrm{CH} 4}$ are shown in relation to trends for acetate fermentation and $\mathrm{CO}_{2}$ reduction. Most of the samples plot near the trend for $\mathrm{CO}_{2}$ reduction, which is interpreted to be the predominant microbial pathway (for some of the samples that plot below the line, especially DE-29, acetate fermentation might also contribute to microbial methanogenesis). Of 15 samples, 12 have $\delta^{2} \mathrm{H}_{\mathrm{H} 2 \mathrm{O}}$ values within the range of modern or postglacial recharge, and 3 have $\delta^{2} \mathrm{H}_{\mathrm{H} 2 \mathrm{O}}$ values consistent glacial recharge.

For thermogenic methane, $\delta^{2} \mathrm{H}_{\mathrm{CH} 4}$ is not expected to show a relation to $\delta^{2} \mathrm{H}_{\mathrm{H} 2 \mathrm{O}}$; however, the two samples interpreted as having a component of thermogenic methane (shown as red dots on fig. 8) plot in the same area as samples interpreted to have been formed by $\mathrm{CO}_{2}$ reduction using $\mathrm{H}_{2} \mathrm{O}$ with isotopic ratios similar to modern or postglacial groundwater recharge.

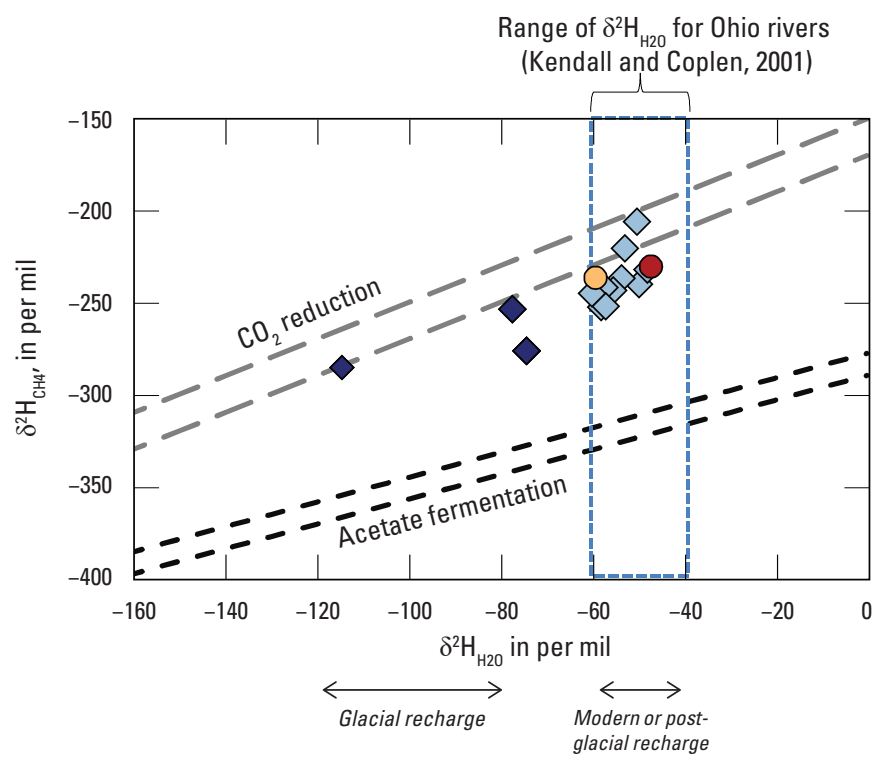

EXPLANATION

Samples from domestic wells

$\diamond \mathrm{H}_{2} \mathrm{O}$ isotopes indicative of modern or post-glacial recharge

$\checkmark \mathrm{H}_{2} \mathrm{O}$ isotopes indicative of glacial recharge

Samples with characteristics of thermogenic methane

SU-23

MT-1286

$\mathrm{CO}_{2}$ reduction (Schoell, 1980): $\delta^{2} \mathrm{H}_{\mathrm{CH} 4}=\delta^{2} \mathrm{H}_{\mathrm{H} 2 \mathrm{O}}-160( \pm 10)$

Acetate fermentation (Waldron and others, 1999): $\delta^{2} \mathrm{H}_{\mathrm{CH} 4}=(.675) \delta^{2} \mathrm{H}_{\mathrm{H} 20}-284( \pm-6)$

Figure 8. Relation between the stable hydrogen isotopic signature of water and methane for samples from domestic wells in Ohio, 2016. 


\section{Carbon Isotope System}

When $\mathrm{CO}_{2}$ enters the groundwater, it speciates into aqueous carbon dioxide $\left(\mathrm{CO}_{2}[\mathrm{aq}]\right)$, carbonic acid $\left(\mathrm{H}_{2} \mathrm{CO}_{3}\right)$, bicarbonate $\left(\mathrm{HCO}_{3}^{-}\right)$, and carbonate $\left(\mathrm{CO}_{3}^{2-}\right)$. The concentration of each species depends on the $\mathrm{pH}$, and at circumneutral $\mathrm{pH}$, the predominant species is $\mathrm{HCO}_{3}^{-}$. Dissolved inorganic carbon (DIC) refers to the total concentration of the four $\mathrm{CO}_{2}$ species.

\section{Carbon-13 of Dissolved Inorganic Carbon}

$\delta^{13} \mathrm{C}_{\mathrm{DIC}}$ of groundwater is derived from two primary sources (Clark and Fritz, 1997): (1) microbial degradation of soil or aquifer-derived organic carbon, which has $\delta^{13} \mathrm{C}_{\mathrm{DIC}}$ of about -25 plus or minus ( \pm ) 2-3 per mil, and (2) dissolution of carbonate minerals, which are typically derived from seawater and have an average value of about 0 per mil. $\delta^{13} \mathrm{C}_{\mathrm{DIC}}$ of groundwater reflects the relative contribution from these two sources, and values for groundwater are typically between about -20 and 0 per mil (Clark and Fritz, 1997).

Samples from 15 domestic wells had $\delta^{13} \mathrm{C}_{\text {DIC }}$ of -31.6 to +18.9 per mil (fig. $9 A$ ). Seven samples had values between -14.8 and -2.9 per mil, which is within the range of typical groundwater. One sample had $\delta^{13} \mathrm{C}_{\mathrm{DIC}}$ of -31.6 per mil, which is depleted relative to soil or aquifer-derived organic matter, and is diagnostic of methane oxidation (see the "Methane Oxidation by Sulfate Reduction" section of this report). Four samples had $\delta^{13} \mathrm{C}_{\text {DIC }}$ greater than +10 per mil, which is diagnostic of Rayleigh-type fractionation (see the "Rayleigh-Type Fractionation" section of this report).

\section{Fractionation of Carbon Isotopes}

Microbial methanogenesis creates substantial ${ }^{13} \mathrm{C}$ fractionation between $\mathrm{CO}_{2}$ and $\mathrm{CH}_{4}$, with a greater degree of fractionation for the $\mathrm{CO}_{2}$ reduction pathway than for acetate fermentation. The degree of ${ }^{13} \mathrm{C}$ fractionation between $\mathrm{CO}_{2}$ and $\mathrm{CH}_{4}$ is represented by the fractionation factor $\left(\alpha^{13} \mathrm{C}_{\mathrm{CO} 2-\mathrm{CH} 4}\right)$, computed as follows:

$$
\alpha^{13} \mathrm{C}_{\mathrm{CO} 2-\mathrm{CH} 4}=\left(\delta^{13} \mathrm{C}_{\mathrm{CO} 2}+1,000\right) /\left(\delta^{13} \mathrm{C}_{\mathrm{CH} 4}+1,000\right)
$$

${ }^{13} \mathrm{C}$ fractionation factors of $1.049-1.095$ are consistent with $\mathrm{CO}_{2}$ reduction, and values of 1.039-1.058 are consistent with acetate fermentation (Whiticar and others, 1986). ${ }^{13} \mathrm{C}$ fractionation factors of 1.0005-1.03 are indicative of methane oxidation or thermogenic methane.

For this study, samples were analyzed for $\delta^{13} \mathrm{C}_{\mathrm{DIC}}$, and $\delta^{13} \mathrm{C}_{\mathrm{CO} 2}$ was estimated by subtracting 8 per mil, which is the approximate equilibrium isotopic fractionation between $\mathrm{CO}_{2}$ and $\mathrm{HCO}_{3}{ }^{-}$at 25 degrees Celsius $\left({ }^{\circ} \mathrm{C}\right.$ ) (Clark and Fritz, 1997). Using this approximation, samples from 15 domestic wells had $\alpha^{13} \mathrm{C}_{\mathrm{CO} 2-\mathrm{CH} 4}$ of 1.021-1.077 (fig. 9B). A total of 12 samples had $\alpha^{13} \mathrm{C}_{\mathrm{CO} 2-\mathrm{CH} 4}$ consistent with $\mathrm{CO}_{2}$ reduction. Four of the 12 samples had values that are also consistent with acetate fermentation. A total of three samples had values between 1.021 and 1.039, within the range for methane oxidation or thermogenic methane. Of these samples, two (SU-23, MT-1286) are interpreted as having a component of thermogenic methane based on $\delta^{13} \mathrm{C}_{\mathrm{CH} 4}$ and $\mathrm{C}_{1} /\left(\mathrm{C}_{2}+\mathrm{C}_{3}\right)$. The third sample (CR-63) had $\delta^{13} \mathrm{C}_{\mathrm{DIC}}$ of -31.6 per mil, which is diagnostic for methane oxidation (see the "Methane Oxidation by Sulfate Reduction" section). 

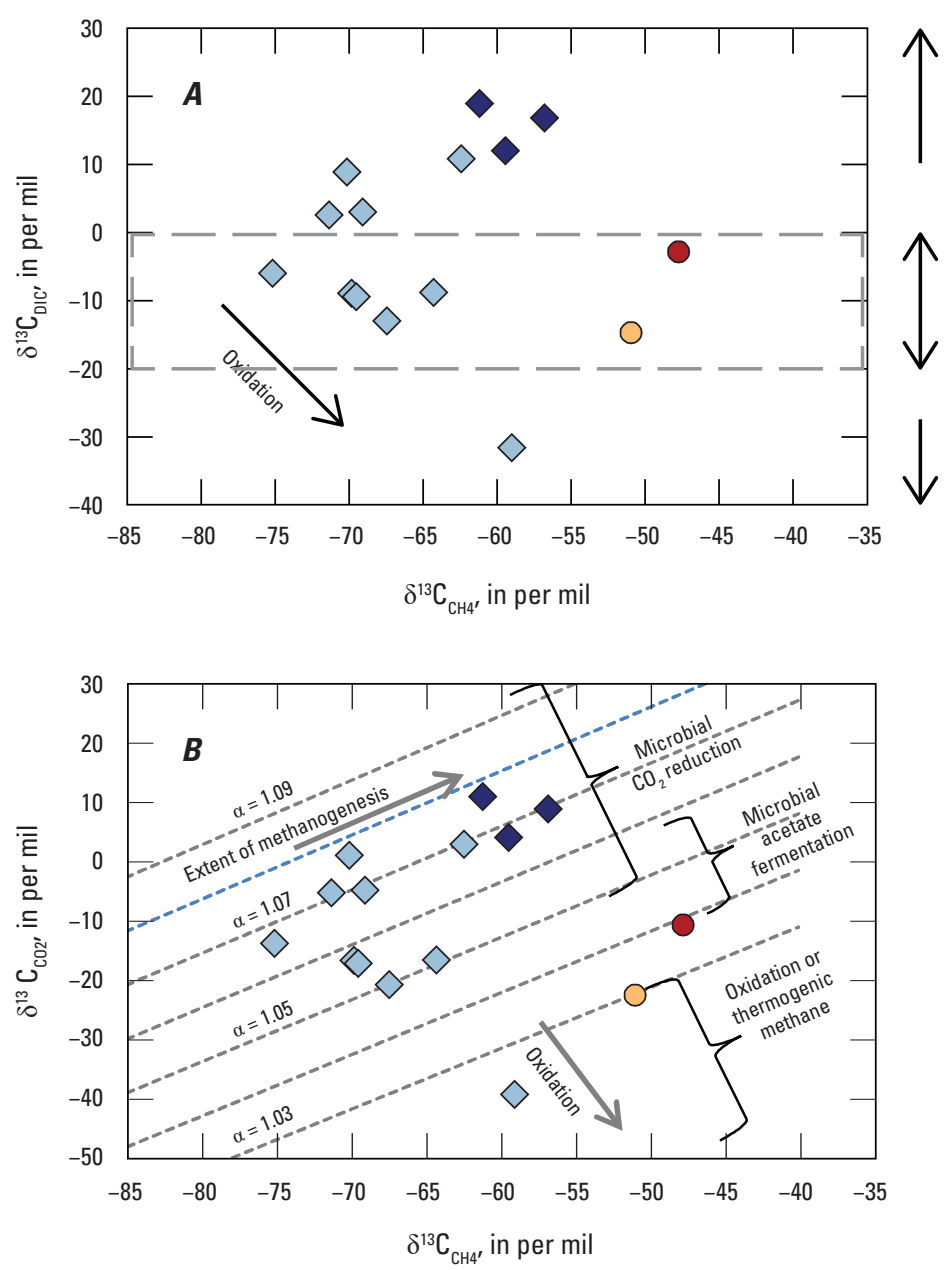

Enriched $\delta^{13} \mathrm{C}_{\text {DIC }}$ : greater than +10 per mil

Range of $\delta^{13} C_{D I C}$ in typical groundwater: -20 to 0 per mil

Depleted $\delta^{13} \mathrm{C}_{\mathrm{DIC}}$ : less than -27 per mil

\section{EXPLANATION}

$\diamond \mathrm{H}_{2} \mathrm{O}$ isotopes indicative of modern or post-glacial recharge

$\mathrm{H}_{2} \mathrm{O}$ isotopes indicative of glacial recharge

Samples with characteristics of thermogenic methane

- SU-23

O MT-1286

$\alpha={ }^{13} \mathrm{C}$ fractionation factor $=\alpha^{13} \mathrm{C}_{\mathrm{CO2}-\mathrm{CH} 4}=\left(\delta^{13} \mathrm{C}_{\mathrm{CO2}}+1000\right) /\left(\delta^{13} \mathrm{C}_{\mathrm{CH} 4}+1000\right)$

Figure 9. Stable carbon isotopic signature $\left(\delta^{13} \mathrm{C}\right)$ of methane in relation to $A, \delta^{13} \mathrm{C}$ of dissolved inorganic carbon and $B, \delta^{13} \mathrm{C}$ of carbon dioxide and $\delta^{13} \mathrm{C}$ fractionation factors for samples from Ohio domestic wells, 2016. 


\section{Rayleigh-Type Fractionation}

In a partially closed groundwater system, the supply of $\mathrm{CO}_{2}$ from the soil zone is limited; therefore, as methanogenesis proceeds, the residual $\mathrm{CO}_{2}$ becomes isotopically heavier and as a result, $\delta^{13} \mathrm{C}_{\mathrm{CH} 4}$ also becomes isotopically heavier. The progressive isotopic enrichment of the precursor $\left(\mathrm{CO}_{2}\right)$ and product $\left(\mathrm{CH}_{4}\right)$ in a partially closed system is attributed to Rayleigh-type fractionation (Coleman and others, 1988). $\delta^{13} \mathrm{C}_{\mathrm{DIC}}$ heavier than about +10 per mil is strong evidence for microbial methanogenesis in a partially closed groundwater system (Martini and others, 2003; Schoell, 1980, 1988).

A total of four samples from domestic wells had $\delta^{13} \mathrm{C}_{\mathrm{DIC}}$ values of +10.8 to +18.9 per mil, consistent with $\mathrm{CO}_{2}$ reduction in a partially closed system (fig. $9 A$ ). Two of the samples are from wells in northwestern Ohio, where glacial lakebed clays inhibit recharge to the underlying black shale (Eberts and George, 2000). The other two samples are from the deepest wells sampled for this study (301 and $345 \mathrm{ft}$ ), which tap coal-bearing Pennsylvanian-age bedrock in eastern Ohio. Of the four samples with enriched $\delta^{13} \mathrm{C}_{\text {DIC }}$, three also had $\mathrm{H}_{2} \mathrm{O}$ isotopes indicative of glacial recharge. These observations are generally consistent with a partially closed system that has not been fully flushed with modern or postglacial recharge.

As $\mathrm{CO}_{2}$ reduction proceeds in a partially closed system, $\delta^{13} \mathrm{C}_{\mathrm{DIC}}$ and $\delta^{13} \mathrm{C}_{\mathrm{CH} 4}$ will progressively increase, but the magnitude of fractionation $\left(\alpha^{13} \mathrm{C}_{\mathrm{CO} 2-\mathrm{CH} 4}\right)$ should remain about the same. This trend can be seen on figures $9 A$ and $9 B$; eight samples fall along a trend of increasing $\delta^{13} \mathrm{C}_{\mathrm{DIC}}$ and $\delta^{13} \mathrm{C}_{\mathrm{CH} 4}$ (fig. $9 A$ ), but they all have $\alpha^{13} \mathrm{C}_{\mathrm{CO} 2-\mathrm{CH} 4}$ between 1.066 and 1.077 (fig. $9 B$ ).

\section{Methane Oxidation by Sulfate Reduction}

Methane can be oxidized in an anaerobic environment in the presence of sulfate $\left(\mathrm{SO}_{4}\right)$, which acts as an electron acceptor. Methane oxidation by sulfate reduction is most likely to occur near the interface of sulfate-reducing and methanogenic zones (Martini and others, 2003). The net reaction is represented by the following equation:

$$
\mathrm{CH}_{4}+\mathrm{SO}_{4}{ }^{2-} \rightarrow \mathrm{HCO}_{3}^{-}+\mathrm{HS}^{-}+\mathrm{H}_{2} \mathrm{O}
$$

Methane oxidation is the opposite of $\mathrm{CO}_{2}$ reduction in that $\mathrm{CH}_{4}$ is the reactant and $\mathrm{CO}_{2}$ is the product. Oxidation of methane is a microbial process and therefore tends to favor lighter isotopes, and as the reaction proceeds, the $\delta^{13} \mathrm{C}$ of the product $\left(\delta^{13} \mathrm{C}_{\mathrm{CO} 2}\right.$ or $\left.\delta^{13} \mathrm{C}_{\mathrm{DIC}}\right)$ is depleted while the residual reac$\operatorname{tant}\left(\delta^{13} \mathrm{C}_{\mathrm{CH} 4}\right)$ is enriched. $\delta^{13} \mathrm{C}_{\mathrm{DIC}}$ less than about -27 per mil is evidence of oxidation of methane (Martini and others, 2003; Whiticar and others, 1986; Whiticar, 1999).

One sample (CR-63) had a $\delta^{13} \mathrm{C}_{\mathrm{DIC}}$ of -31.6 per mil, which is in the range of values diagnostic for methane oxidation (fig. 9A). CR-63 was the shallowest well sampled for this study $(75 \mathrm{ft})$. The water showed evidence of sulfate reduction in terms of high concentrations of $\mathrm{SO}_{4}(233 \mathrm{mg} / \mathrm{L})$ and sulfide $(0.4 \mathrm{mg} / \mathrm{L})$, an extremely strong rotten egg odor, and an abundance of fine black particulates (presumably sulfide mineral precipitates.) On the Whiticar plot (fig. 7A) and Bernard plot (fig. 7B), CR-63 shows isotopic and compositional shifts that are expected as a result of methane oxidation, as indicated by the arrows on the diagrams. 


\section{Carbon-14 of Methane}

Carbon-14 $\left({ }^{14} \mathrm{C}\right)$ is a radioactive isotope of carbon that forms from cosmic radiation in the upper atmosphere. ${ }^{14} \mathrm{C}$ has a half-life of 5,730 years and can be detected in organic materials that are less than about 50,000 years old (Coleman and others, 1995). ${ }^{14} \mathrm{C}$ concentrations are expressed as percent modern carbon (pMC); $100 \mathrm{pMC}$ represents the ${ }^{14} \mathrm{C}$ concentration of $\mathrm{CO}_{2}$ in the atmosphere before the start of atomic-bomb testing in about $1953 .{ }^{14} \mathrm{C}$ concentrations can be greater than 100 percent for organic matter younger than about 1953.

${ }^{14} \mathrm{C}$ of methane $\left({ }^{14} \mathrm{C}_{\mathrm{CH} 4}\right)$ is not directly related to the time of methane formation but can provide information about the relative age of the carbon precursor. Coleman and others (1995) proposed that methane formed in landfills or sewers should have ${ }^{14} \mathrm{C}_{\mathrm{CH} 4}$ similar to currently living materials (120-150 pMC), swamp and marsh gases should have ${ }^{14} \mathrm{C}_{\mathrm{CH} 4}$ of about $30-120 \mathrm{pMC}$, methane formed from carbon in younger (less than 50,000 years) glacial deposits should have ${ }^{14} \mathrm{C}_{\mathrm{CH} 4}$ less than about $30 \mathrm{pMC}$, and methane formed from carbon in Paleozoic bedrock or older glacial deposits (more than
50,000 years) should have no detectable ${ }^{14} \mathrm{C}_{\mathrm{CH} 4}$ (these may be broad generalizations because the concentration of ${ }^{14} \mathrm{C}$ in the atmosphere has varied through geologic time [Plummer and others, 2004]).

Of the 15 samples, 14 had sufficient concentrations of methane to analyze for ${ }^{14} \mathrm{C}_{\mathrm{CH} 4}$ (fig. 10). A total of eight samples had ${ }^{14} \mathrm{C}_{\mathrm{CH} 4}$ less than the reporting limit of $0.4 \mathrm{pMC}$, consistent with methane formed from carbon in Paleozoic bedrock or older glacial deposits. A total of six samples had ${ }^{14} \mathrm{C}_{\mathrm{CH} 4}$ of 0.9-13.5 pMC, consistent with methane formed from organic matter in younger glacial deposits. None of the samples had ${ }^{14} \mathrm{C}_{\mathrm{CH} 4}$ expected to occur in methane from landfills, swamps, marshes, or other near-surface environments where acetate fermentation is expected to be the predominant pathway of microbial methanogenesis.

Of the two samples with components of thermogenic methane, one sample (SU-23) had a ${ }^{14} \mathrm{C}_{\mathrm{CH} 4}$ value of 1.60, consistent with carbon from younger glacial deposits. The second sample with a component of thermogenic methane (MT-1286) did not have a sufficient $\mathrm{CH}_{4}$ concentration for determination of ${ }^{14} \mathrm{C}_{\mathrm{CH} 4}$.

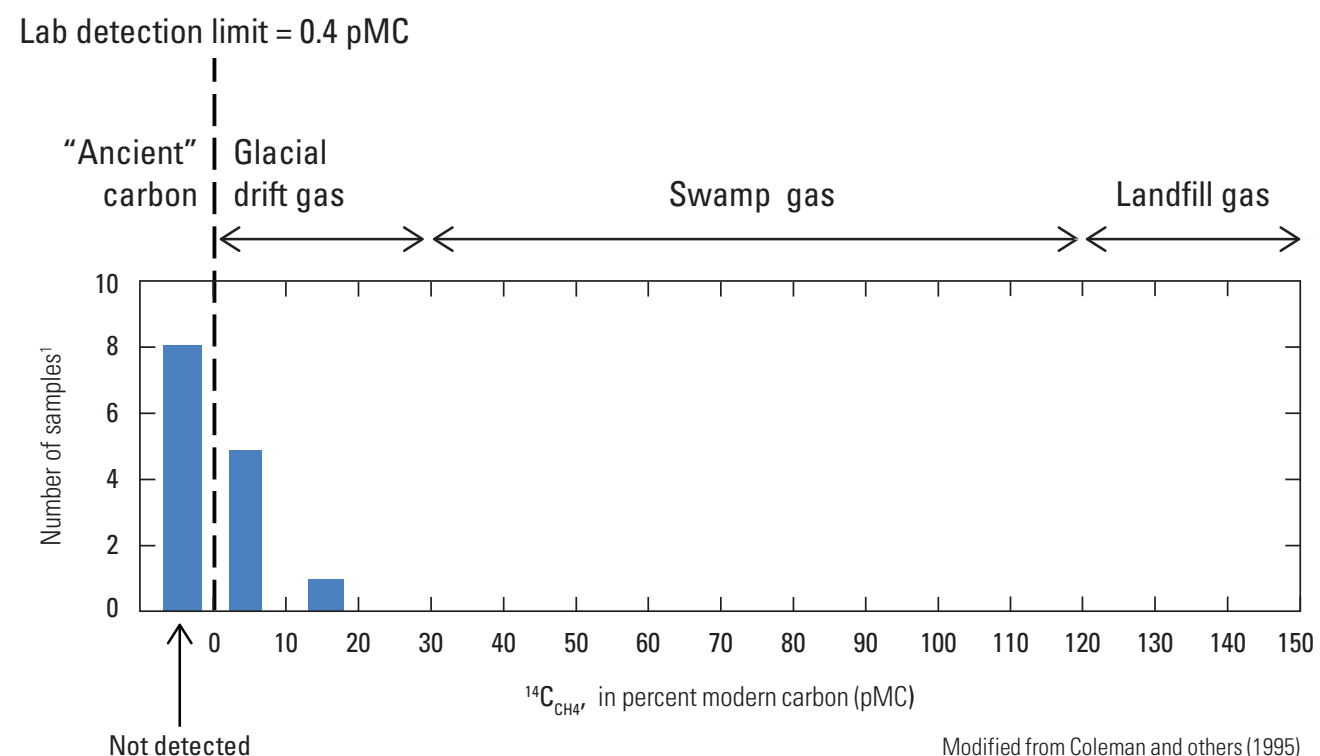

'Not measured for MT-1286 because the $\mathrm{CH} 4$ concentration was too low.

Figure 10. Carbon-14 of methane from domestic wells in Ohio, 2016. 


\section{Interpretation of Methane Origin}

A well-by-well summary of chemical and isotopic characteristics used to evaluate methane origin is presented in table 7. Most of the samples have values consistent with microbial methanogenesis by $\mathrm{CO}_{2}$ reduction, based on the following criteria: (1) $\delta^{13} \mathrm{C}_{\mathrm{CH} 4}$ less than -60 or -55 per mil (Schoell, 1980; Whiticar and others, 1986) and (or) $\delta^{13} \mathrm{C}_{\mathrm{DIC}}$ greater than +10 per mil (Martini and others, 1998);

(2) $\mathrm{C}_{1} /\left(\mathrm{C}_{2}+\mathrm{C}_{3}\right)$ greater than 1,000 (Bernard and others, 1978);

(3) $\alpha^{13} \mathrm{C}_{\mathrm{CO} 2-\mathrm{CH} 4}$ equal to 1.047 to 1.095 (Whiticar and others,
1986); and (4) $\alpha^{2} \mathrm{H}_{\mathrm{H} 2 \mathrm{O}-\mathrm{CH} 4}$ equal to about 1.2 (Schegel and others, 2011; Martini and others, 1998). Values that are outside of these ranges are highlighted in table 7.

For 11 of 15 samples, all constituents are within the ranges of the above criteria for microbial $\mathrm{CO}_{2}$ reduction (ST139, ST-140, ST-141, CO-31, MU-128, AB-142, GE-368, GR-755, DE-28, DE-29, and HY-53). A 12th sample (PE-59) met three of the four criteria, except that $\mathrm{C}_{1} /\left(\mathrm{C}_{2}+\mathrm{C}_{3}\right)$ was 212 , which is in between commonly used diagnostic values for microbial (greater than 1,000) and thermogenic (less than 100) methane. For this discussion, PE-59 is included as one of the 12 samples interpreted as microbial.

Table 7. Chemical and isotopic characteristics of methane and related constituents from domestic wells in Ohio, 2016.

[Shading indicates values outside of ranges diagnostic for carbon dioxide reduction; $\delta$, isotopic ratio delta notation; $\alpha$, isotopic fractionation factor; $\mathrm{C}$, carbon; $\mathrm{H}$, hydrogen; $\mathrm{CH}_{4}$, methane; $\mathrm{C}_{1}$, methane; $\mathrm{C}_{2}$, ethane; $\mathrm{C}_{3}$, propane; DIC, dissolved inorganic carbon; $\mathrm{CO}_{2}$, carbon dioxide; $\mathrm{H}_{2} \mathrm{O}$, water; per mil, parts per thousand; <, less than; - -, not measured because methane concentration was too low]

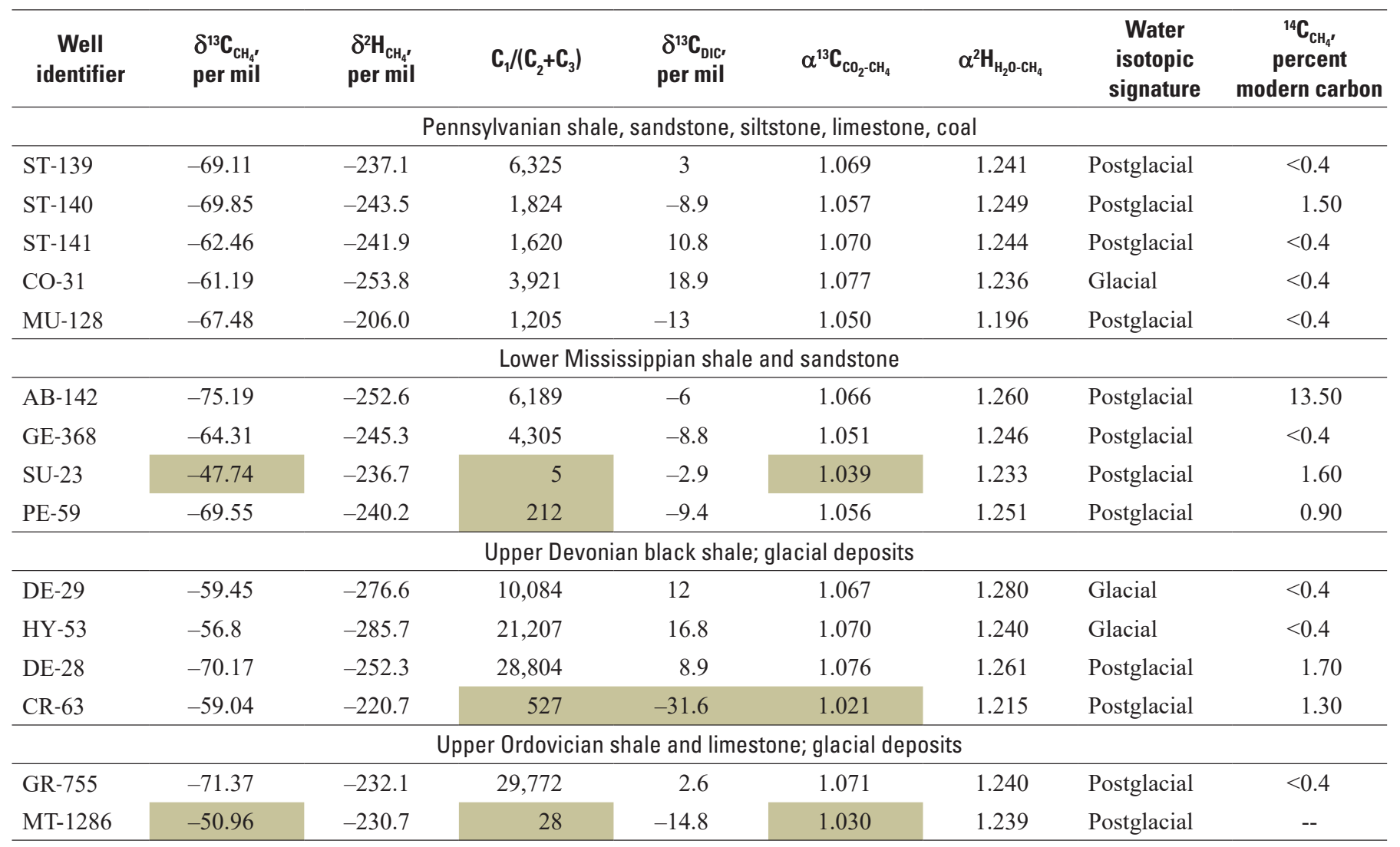




\section{Samples with Chemical and Isotopic Characteristics Consistent with Microbial Methane}

A total of 12 samples had chemical and isotopic characteristics consistent with microbial methane formed predominantly by the $\mathrm{CO}_{2}$ reduction pathway. Where three or more samples were analyzed from the same aquifer, $\delta^{13} \mathrm{C}_{\mathrm{CH} 4}$ showed a range of values. Samples from Upper Devonian black shale had values from -70.17 to -56.8 per mil, Lower Mississippian shale and sandstone had values from -75.19 to -64.31 per mil, and Pennsylvanian bedrock had values from -69.85 to -61.19 per mil. For each of these aquifers, there was a general trend of increasing $\delta^{13} \mathrm{C}_{\mathrm{CH} 4}$ with depth (fig. 11). This observation is consistent with increased Rayleigh-type fractionation at increased depths, where the groundwater is increasingly isolated, and residence time in the zone of methanogenesis increases.

Although the data for 12 samples are generally consistent with a microbial origin, other interpretations are possible; for example, the increase in $\delta^{13} \mathrm{C}_{\mathrm{CH} 4}$ with depth could also be interpreted as increased mixing with thermogenic methane (and possibly brine) migrating from greater depths. This alternate interpretation could be especially applicable to wells in eastern Ohio, which generally have lower dryness and higher concentrations of chloride and bromide, as compared to wells in western Ohio. Harkness and others (2017) concluded that methane detected in groundwater of north-central West Virginia was predominantly microbial, but there was a pervasive signature of thermogenic methane, partly based on widespread detections of ethane.

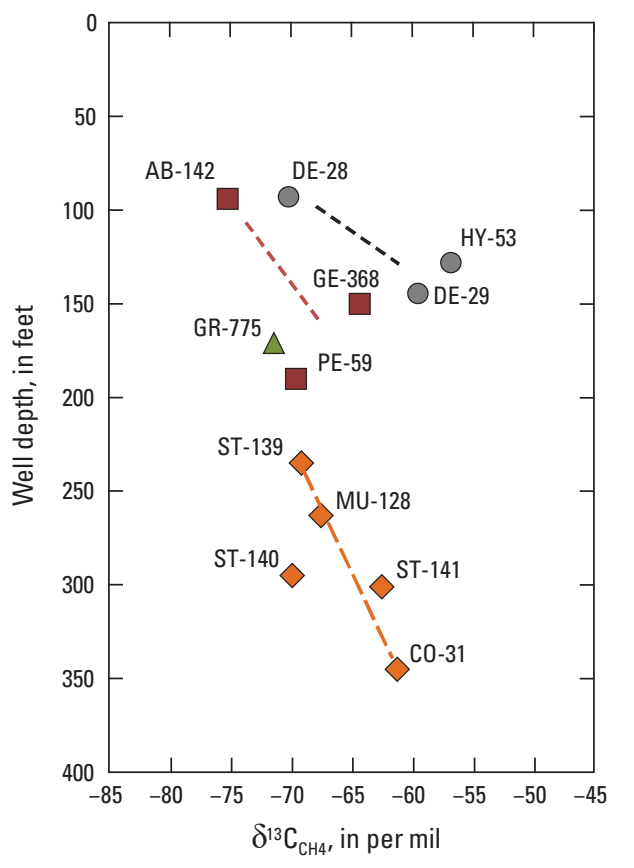

EXPLANATION

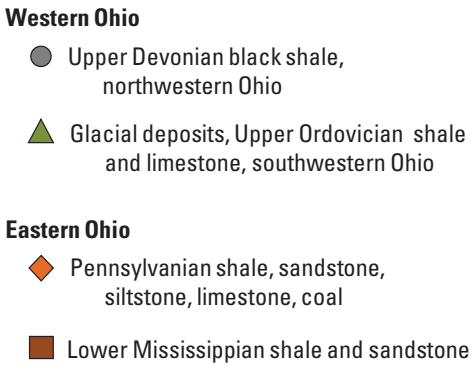

Lower Mississippian shale and sandstone

Figure 11. Stable carbon isotopic signature of methane in relation to well depth and geologic formation for 12 samples interpreted as microbial methane formed by carbon dioxide reduction in Ohio domestic wells, 2016. 


\section{Samples with Chemical and Isotopic Characteristics not Consistent with Microbial Methane}

A total of three samples had multiple chemical and (or) isotopic characteristics outside of the ranges diagnostic for microbial methane formed predominantly by $\mathrm{CO}_{2}$ reduction (indicated as highlighted cells on table 7). A sample from the shallowest well (CR-63) had chemical and isotopic characteristics consistent with methane oxidation by sulfate reduction. The strongest evidence for methane oxidation is a light $\delta^{13} \mathrm{C}_{\mathrm{DIC}}$ of -31.6 per mil (fig. $9 \mathrm{~A}$ ). Additional observations in support of the interpretation include moderately heavy $\delta^{13} \mathrm{C}_{\mathrm{CH} 4}$ $\left(-59.04\right.$ per mil) and $\delta^{2} \mathrm{H}_{\mathrm{CH} 4}(-220.7$ per mil), relatively low dryness (527), and low $\alpha^{13} \mathrm{C}_{\mathrm{CO} 2-\mathrm{CH} 4}(1.021)$. In addition, the water showed strong evidence of $\mathrm{SO}_{4}$ reduction in the form of high concentrations of $\mathrm{SO}_{4}(233 \mathrm{mg} / \mathrm{L})$ and hydrogen sulfide $(0.401 \mathrm{mg} / \mathrm{L})$, a strong rotten egg odor, and abundant black particles in the water (presumably sulfide mineral precipitate). The sample was from a 75-ft well that taps Upper Devonian black shale in an area of north-central Ohio, near the boundary of the Appalachian Basin and the Indiana-Ohio Platform.

Two samples (SU-23 and MT-1286) were interpreted as having a component of thermogenic methane based on (1) $\delta^{13} \mathrm{C}_{\mathrm{CH} 4}$ of -47.17 and -50.96 per mil, (2) dryness values of 5 and 28 (figs. $7 A, 7 B$ ), and (3) the presence of butane $\left(\mathrm{C}_{4}\right)$ and pentane $\left(\mathrm{C}_{5}\right)$ compounds. Both samples showed evidence for mixing with modern or postglacial recharge and (or) microbial methane based on (1) stable isotopes of $\mathrm{H}_{2} \mathrm{O}$ are indicative of modern or postglacial recharge; (2) the relation between $\delta^{2} \mathrm{H}_{\mathrm{H} 2 \mathrm{O}}$ and $\delta^{2} \mathrm{H}_{\mathrm{CH} 4}$ is consistent with $\mathrm{CO}_{2}$ reduction (fig. 7); (3) $\delta^{13} \mathrm{C}_{\mathrm{DIC}}$ is within the range of typical groundwater (fig. $8 A$ ); and $(4){ }^{14} \mathrm{C}_{\mathrm{CH} 4}$ is detected in SU-23 at $1.6 \mathrm{pMC}$, which is not consistent with a solely thermogenic source (Coleman and others, 1995).

One additional sample (PE-59) might also contain some thermogenic methane, based on gas composition; dryness was 212 , which is in between diagnostic values for microbial (greater than 1,000) and thermogenic (less than 100) methane (fig. $7 B$ ). A decrease in dryness could be attributed to oxidation of microbial methane, but small concentrations of isobutane ( 0.0028 mole percent) and iso-pentane $(0.0006$ mole percent) were detected. It is uncertain if such low concentrations of these compounds can be the result of microbial processes. For this analysis, the methane in PE-59 is considered to be predominantly microbial.

The chemical and isotopic data collected for this study were not sufficient to distinguish whether thermogenic methane in SU-23 or MT-1286 (and possibly PE-59) is the result of (1) natural migration of a deep-seated source of methane or (2) contamination with stray gas related to human activities. The sample with the strongest thermogenic signature (SU-23) is from a well on the margin of a deep buried valley incised into Upper Devonian black shale. In addition, the well is near the Middleburg Fault, a major fault that extends to basement rocks (Baranoski, 2013). One or both of these features could serve as natural migration pathways for discharge of water and (or) gas from the regional flow system. On the other hand, there are multiple active and abandoned hydrocarbon wells near SU-23, any of which could serve as a manmade pathway of migration for thermogenic methane. 


\section{Limitations of the Study}

The study has several limitations and uncertainties; some are related to the study design, and others are related to the methods of analysis. In terms of study design, the primary limitations are listed below.

1. The relatively small number of wells sampled is a limitation because hydrogeologic settings where methane occurs in groundwater may not be represented in the network of 15 wells sampled for this study.

2. Multiple potential natural and anthropogenic migration pathways exist near most of the wells, especially those in eastern Ohio. This creates some uncertainty as to whether the methane samples are "naturally occurring" or not.

3. Most of the wells were constructed with long open intervals that ranged from 15 to $302 \mathrm{ft}$. This adds uncertainty about which horizons are the source of the water and methane; for example, it is possible that methane was from one horizon and water was from another. In addition, the water sampled could represent a mix from multiple horizons, and this could obscure diagnostic relations between water quality and gas characteristics.

4. A single sample was collected from each well, so it is not possible to assess temporal variability of the data.

5. Additional types of chemical and isotopic analyses could have been useful; for example, isotopes of higher-chain hydrocarbons and (or) noble gases may have provided additional information about migration pathways, mixing, or oxidation (Harkness and others, 2017).

Additional limitations are related to uncertainties and inconsistencies with established techniques for investigating methane origin using isotopic and chemical signatures (Bates and others, 2011; Golding and others, 2013; Vinson and others, 2017; and Harkness and others, 2017).
6. As discussed in earlier sections of this report, secondary processes can obscure original isotopic and (or) chemical signatures; for example, oxidation of microbial methane can create isotopic shifts similar to mixing of microbial and thermogenic methane. $\mathrm{CO}_{2}$ reduction in a partially closed system can also cause isotopic shifts that could be interpreted as mixing microbial methane with thermogenic methane.

7. There is some uncertainty about the amount and types of higher-chain hydrocarbons that can be produced by microbial processes (Hinrichs and others, 2006; Osborn and McIntosh, 2010), and this adds uncertainty to differentiation of microbial and thermogenic methane.

8. Some of the data used to define isotopic signatures for microbial methane were from recent sediments or lab cultures, and there is uncertainty about how well the data represent microbial methanogenesis using organic matter in shale or coal (Vinson and others, 2017).

9. There is some uncertainty about ${ }^{13} \mathrm{C}$ fractionation factors diagnostic of microbial pathways of methanogenesis. Bates and others (2011) noted that values of $\alpha^{13} \mathrm{C}_{\mathrm{CO} 2-\mathrm{CH} 4}$ were developed for methanogenesis in an open system, whereas a partially closed system might be more applicable. Vinson and others (2017) noted $\alpha^{13} \mathrm{C}_{\mathrm{CO} 2-\mathrm{CH} 4}$ values can be affected by nonmethanogenic processes that produce or consume $\mathrm{CH}_{4}$ and (or) $\mathrm{CO}_{2}$.

10. There is some evidence that secondary microbial methanogenesis can alter the isotopic composition of methane from thermogenic gas reservoirs. Isotopically enriched $\delta^{13} \mathrm{C}_{\mathrm{DIC}}$ is considered to be unequivocal evidence of microbial methanogenesis (Martini and others, 2003); however, enriched $\delta^{13} \mathrm{C}_{\mathrm{DIC}}(+8$ to +12 per mil) has been detected in commercial wells that produce methane from thermogenic gas reservoirs (Osborn and McIntosh, 2010; Sharma and others, 2014). 


\section{Summary and Conclusions}

In 2016, the U.S. Geological Survey, in cooperation with the Ohio Water Development Authority, investigated methane in Ohio groundwater, and the results are presented in this report. The objectives were to (1) identify a network of domestic wells that produce methane, (2) describe the hydrogeologic settings in which methane is detected, (3) document the chemical and isotopic characteristics of the methane and the coexisting water, and (4) evaluate the origin of the methane, to the extent possible.

A total of 15 domestic water wells were selected from 12 counties in diverse parts of Ohio. The wells were 75-345 feet deep and tapped a range of aquifers, including Pleistocene glacial deposits and four bedrock units:

Pennsylvanian shale, sandstone, siltstone, limestone, and coal; Lower Mississippian shale and sandstone; Upper Devonian organic-rich shale; and Upper Ordovician shale and limestone. The unconsolidated glacial deposits overlying bedrock were from 4 to more than 171 feet thick. A similarity among the 15 wells is that the bedrock is predominantly shale, and the glacial deposits are predominantly clay.

The wells were sampled once during 2016. Samples were analyzed for major ions, nutrients, trace elements, arsenic speciation, and dissolved organic carbon at the U.S. Geological Survey National Water Quality Laboratory. Isotech Laboratories analyzed the samples for concentrations of methane and other dissolved gases; stable isotopes (carbon, hydrogen, and oxygen) of methane, water, and dissolved inorganic carbon; and 14-carbon of methane.

The isotopic composition of water $\left(\delta^{18} \mathrm{O}_{\mathrm{H} 2 \mathrm{O}}, \delta^{2} \mathrm{H}_{\mathrm{H} 2 \mathrm{O}}\right)$ can provide information about its origin. Samples from the domestic wells had $\delta^{18} \mathrm{O}_{\mathrm{H} 2 \mathrm{O}}$ of -16.05 to -7.15 parts per thousand (per mil), and $\delta^{2} \mathrm{H}_{\mathrm{H} 2 \mathrm{O}}$ of -114.6 to -47.1 per mil. All samples had isotopic ratios consistent with water that originated as precipitation. Of the 15 samples, 12 had isotopic ratios consistent with modern or postglacial groundwater recharge, and 3 had lighter isotopic signatures, consistent with glacial recharge. The occurrence of isotopically light $\mathrm{H}_{2} \mathrm{O}$ indicates that the aquifers have not been fully flushed by modern or postglacial recharge.

Concentrations of methane ranged from 1.2 to 120 milligrams per liter $(\mathrm{mg} / \mathrm{L})$. Of the 15 samples, 12 had methane concentrations greater than $28 \mathrm{mg} / \mathrm{L}$, the level that poses a risk for explosion. The samples had a wide range of water quality: $\mathrm{pH}$ ranged from 7.0 to 9.0; alkalinity ranged from 225 to $889 \mathrm{mg} / \mathrm{L}$ as $\mathrm{CaCO}_{3}$; dissolved solids ranged from 398 to $2,940 \mathrm{mg} / \mathrm{L}$; and chloride ranged from 7.04 to $1,350 \mathrm{mg} / \mathrm{L}$. Water types ranged from $\mathrm{CaMgHCO}_{3}$ (generally characteristic of shallow, recently recharged water) to $\mathrm{NaCl}$ (generally characteristic of deeper, older waters). Methane is not expected to coexist with electron acceptors such as dissolved oxygen, nitrate, or sulfate; however, one or more of these constituents were detected in six samples, which indicates that some of the samples were a mix of water from multiple horizons with different redox conditions.
Stable isotopes of methane $\left(\delta^{13} \mathrm{C}_{\mathrm{CH} 4}, \delta^{2} \mathrm{H}_{\mathrm{CH} 4}\right)$ are used to differentiate thermogenic and microbial methane. In general, microbial methane is isotopically lighter than thermogenic methane because microbes preferentially utilize lighter isotopes, which have weaker bonds that are easier to break. $\delta^{13} \mathrm{C}_{\mathrm{CH} 4}$ greater than -45 to -50 per mil is diagnostic for thermogenic methane, and $\delta^{13} \mathrm{C}_{\mathrm{CH} 4}$ less than about -60 or -55 per mil is diagnostic for microbial methane. Samples from this study had $\delta^{13} \mathrm{C}_{\mathrm{CH} 4}$ of -75.19 to -47.7 per mil and $\delta^{2} \mathrm{H}_{\mathrm{CH} 4}$ of -285.7 to -206 per mil. On a Whiticar plot, which shows $\delta^{13} \mathrm{C}_{\mathrm{CH} 4}$ versus $\delta^{2} \mathrm{H}_{\mathrm{CH} 4}, 12$ of 15 samples plot in the fields for microbial methane, 1 sample plots in the field for thermogenic methane, and 2 samples plot in between.

Another characteristic used to differentiate microbial and thermogenic methane is gas dryness, the ratio of methane $\left(\mathrm{C}_{1}\right)$ to the sum of ethane $\left(\mathrm{C}_{2}\right)$ and propane $\left(\mathrm{C}_{3}\right)\left(\mathrm{C}_{1} /\left[\mathrm{C}_{2}+\mathrm{C}_{3}\right]\right)$. Thermogenic gas typically includes substantial concentrations of higher-chain hydrocarbons whereas microbial gas is predominantly methane with minor amounts of ethane and propane. In general, gas dryness greater than about 1,000 is diagnostic for microbial methane, and dryness less than 100 is diagnostic for thermogenic methane. Samples from domestic wells had gas dryness of 5-29,772. On a Bernard plot, which shows $\delta^{13} \mathrm{C}_{\mathrm{CH} 4}$ in relation to gas dryness, 11 samples plot in the field for microbial methane, 1 sample plots in the field for thermogenic methane, and 3 samples plot in between. Interpretations of methane origin based on methane isotopes and gas dryness can be ambiguous because secondary processes (mixing, migration, and oxidation) can alter the original values. For example, several processes can cause an increase in $\delta^{13} \mathrm{C}_{\mathrm{CH} 4}$, including mixing microbial methane with thermogenic methane, oxidation of methane by microbial processes, and Rayleigh-type fractionation in a partially closed system.

A generalized interpretation of the Whiticar and Bernard plots is that 13 samples can be interpreted as predominantly microbial, and 2 samples (SU-23 and MT-1286) can be interpreted as having a component of thermogenic methane.

There are two primary pathways of microbial methanogenesis - acetate fermentation and $\mathrm{CO}_{2}$ reduction. In general, acetate fermentation is associated with younger, fresher organic matter and warmer temperatures in nearsurface environments, such as marshes, wetlands, landfills, and sewers. $\mathrm{CO}_{2}$ reduction is associated with older organic matter and cooler temperatures in the subsurface and is the predominant pathway associated with groundwater systems, marine sediments, and relatively shallow deposits of microbial shale gas and coal bed methane.

The two microbial pathways result in different degrees of fractionation of hydrogen isotopes. For $\mathrm{CO}_{2}$ reduction, all the $\mathrm{H}$ in $\mathrm{CH}_{4}$ is derived from coexisting water, whereas for the acetate fermentation pathway, hydrogen is derived from water and acetate. As a result, methane formed by acetate fermentation shows a greater degree of $\mathrm{H}$ fractionation than methane formed by $\mathrm{CO}_{2}$ reduction. Based on relations between $\delta^{2} \mathrm{H}_{\mathrm{CH} 4}$ and $\delta^{2} \mathrm{H}_{\mathrm{H} 2 \mathrm{O}}, \mathrm{CO}_{2}$ reduction is the predominant pathway of microbial methanogenesis, although acetate fermentation 
may contribute to methanogenesis for some samples. The three samples with isotopically light $\mathrm{H}_{2} \mathrm{O}$ also have light $\delta^{2} \mathrm{H}$ of methane, and as a result, these samples plot in/near the field for acetate fermentation on a Whiticar plot; however, other evidence indicates that $\mathrm{CO}_{2}$ reduction was the primary microbial pathway of methane formation.

Microbial methanogenesis creates substantial fractionation of carbon isotopes between $\mathrm{CO}_{2}$ (or DIC) and $\mathrm{CH}_{4}$, with a greater degree of fractionation for the $\mathrm{CO}_{2}$ reduction than for acetate fermentation. The degree of ${ }^{13} \mathrm{C}$ fractionation between $\mathrm{CO}_{2}$ and $\mathrm{CH}_{4}$ is indicated by the fractionation factor represented as $\alpha^{13} \mathrm{C}_{\mathrm{CO} 2-\mathrm{CH} 4}$. A total of 12 samples had $\alpha^{13} \mathrm{C}_{\mathrm{CO} 2-\mathrm{CH} 4}$ of $1.050-1.077$, within the range for microbial methanogenesis, and 3 samples had values between 1.021 and 1.039, within the range for methane oxidation or thermogenic methane.

The samples had a wide range of $\delta^{13} \mathrm{C}_{\mathrm{DIC}}(-31.6$ to +18.9 per mil). Seven samples had values between -14.8 and -2.9 per mil, within the range of typical groundwater. One sample had $\delta^{13} \mathrm{C}_{\mathrm{DIC}}$ of -31.6 per mil, which is depleted relative to soil or aquifer-derived organic matter, and is considered to be diagnostic of methane oxidation. Four samples had $\delta^{13} \mathrm{C}_{\text {DIC }}$ greater than +10 per mil, which is considered to be diagnostic of Rayleigh-type fractionation associated with $\mathrm{CO}_{2}$ reduction in a partially closed groundwater system.

Carbon-14 $\left({ }^{14} \mathrm{C}\right)$ is a radioactive isotope of carbon that can be detected in organic materials less than about 50,000 years old. The concentration of ${ }^{14} \mathrm{C}$ in methane can provide information about the relative age of the carbon source. Eight samples had ${ }^{14} \mathrm{C}_{\mathrm{CH} 4}$ less than the reporting limit of $0.4 \mathrm{pMC}$, consistent with methane formed from carbon in Paleozoic bedrock or older glacial deposits. Six samples had ${ }^{14} \mathrm{C}_{\mathrm{CH} 4}$ of $0.9-13.5 \mathrm{pMC}$, consistent with methane formed from organic matter in younger glacial deposits. One sample did not have a sufficient $\mathrm{CH}_{4}$ concentration to analyze for ${ }^{14} \mathrm{C}_{\mathrm{CH} 4}$. None of the samples had ${ }^{14} \mathrm{C}_{\mathrm{CH} 4}$ concentrations consistent with methane from landfills, swamps, marshes, or other nearsurface environments where acetate fermentation is expected to be the predominant pathway of microbial methanogenesis.

Overall, 12 samples had chemical and isotopic characteristics consistent with microbial methane formed predominantly by the $\mathrm{CO}_{2}$ reduction pathway. Where multiple samples were analyzed from the same aquifer, $\delta^{13} \mathrm{C}_{\mathrm{CH} 4}$ generally increased with depth. The four samples with the heaviest $\delta^{13} \mathrm{C}_{\mathrm{CH} 4}$ also had the heaviest $\delta^{13} \mathrm{C}_{\mathrm{DIC}}(+10.8$ to +18.9 per mil), and three of the four samples also had $\mathrm{H}_{2} \mathrm{O}$ isotopes indicative of glacial recharge. These observations are generally consistent with $\mathrm{CO}_{2}$ reduction in a partially closed system that has not been fully flushed with modern or postglacial recharge. Two of the samples are from the northwestern corner of Ohio, where a thick layer of glacial lakebed clay inhibits recharge to the underlying Upper Devonian black shale. The other two samples are from the deepest wells (301 and 345 feet), which tap Pennsylvanian bedrock in eastern Ohio.
Other interpretations are also possible; for example, the increase in $\delta^{13} \mathrm{C}_{\mathrm{CH} 4}$ with depth could also be interpreted as increased mixing with thermogenic methane (and possibly brine) migrating from greater depths. This interpretation could be especially applicable to wells in eastern Ohio, which generally have lower $\mathrm{C}_{1} /\left(\mathrm{C}_{2}+\mathrm{C}_{3}\right)$ and higher concentrations of chloride and bromide, as compared to wells in western Ohio.

A total of three samples had chemical and isotopic characteristics that are not consistent with microbial $\mathrm{CO}_{2}$ reduction. The sample from the shallowest well (CR-63) had characteristics consistent with methane oxidation by sulfate reduction $\left(\delta^{13} \mathrm{C}_{\mathrm{DIC}}\right.$ of -31.6 per mil, slightly enriched $\delta^{13} \mathrm{C}_{\mathrm{CH} 4}$, high concentrations of $\mathrm{SO}_{4}$ and sulfide, a rotten egg odor, and an abundance of fine black particulates).

Two samples (SU-23 and MT-1286) were interpreted as having a component of thermogenic methane based on $\delta^{13} \mathrm{C}_{\mathrm{CH} 4}$ $(-47.17$ and -50.96 per mil), dryness (5 and 28$)$, and the presence of butane $\left(\mathrm{C}_{4}\right)$ and pentane $\left(\mathrm{C}_{5}\right)$ hydrocarbons. For both samples, there also was evidence of mixing with modern/ postglacial recharge and (or) microbial methane. The chemical and isotopic data collected for this study were not sufficient to distinguish whether thermogenic methane in SU-23 or MT-1286 (or any of the other wells) is the result of (1) natural migration of deep methane/groundwater or (2) contamination with stray gas related to human activities.

The study has several limitations related to the study design. (1) The number of wells sampled was relatively small, and it is possible that methane occurs in hydrogeologic settings not represented by the well network. (2) Multiple potential natural and anthropogenic migration pathways exist near most of the wells, especially those in eastern Ohio; this creates some uncertainty as to whether the methane samples are naturally occurring or related to human activities. (3) Most of the wells were constructed with long open intervals, so water samples could be a mix from multiple horizons, and this could obscure diagnostic relations between water quality and gas characteristics. (4) A single sample was collected from each well, so it is not possible to assess temporal variability of the data. (5) Additional types of chemical and isotopic analyses may have been useful; for example, isotopes of higher-chain hydrocarbons and (or) noble gases may have provided additional information about migration pathways, mixing, or oxidation.

There also are several uncertainties and inconsistencies associated with the methods of analysis. (1) As discussed in earlier sections of this report, secondary processes can obscure original isotopic and (or) chemical signatures. (2) There is some uncertainty about the amount and types of higher-chain hydrocarbons that can be produced by microbial processes, which can add uncertainty to differentiation of microbial and thermogenic methane. (3) Some of the data used to define isotopic signatures for microbial methane were from recent sediments or lab cultures, and there is uncertainty about how well the data represent microbial methanogenesis using organic matter in shale or coal. There is 
some uncertainty about ${ }^{13} \mathrm{C}$ fractionation factors diagnostic of microbial pathways of methanogenesis. Values of $\alpha^{13} \mathrm{C}_{\mathrm{CO}-\mathrm{CH} 4}$ were developed for methanogenesis in an open system, whereas a partially closed system might be more applicable. In addition, $\alpha^{13} \mathrm{C}_{\mathrm{CO} 2-\mathrm{CH} 4}$ can be affected by nonmethanogenic processes that produce or consume $\mathrm{CH}_{4}$ and (or) $\mathrm{CO}_{2}$. (5) Isotopically enriched $\delta^{13} \mathrm{C}_{\mathrm{DIC}}$ is considered to be unequivocal evidence of microbial methanogenesis; however, enriched $\delta^{13} \mathrm{C}_{\text {DIC }}$ has been detected in commercial wells that produce from thermogenic gas reservoirs.

\section{References Cited}

Back, W., 1966, Hydrochemical facies and ground-water flow patterns in northern part of Atlantic Coastal Plain: U.S. Geological Survey Professional Paper 498-A, 42 p.

Baldassare, F.J., McCaffrey, M.A., and Harper, J.A., 2014, A geochemical context for stray gas investigations in the northern Appalachian Basin-Implications of analyses of natural gases from Neogene- through Devonian-age strata: AAPG Bulletin, v. 98, no. 2, p. 341-372. [Also available at https://doi.org/10.1306/06111312178.]

Baranoski, M.T., 2013, Structure contour map on the Precambrian unconformity surface in Ohio and related basement features (ver. 2.0): Columbus, Ohio Department of Natural Resources, Division of Geological Survey Map Series PG-23, scale 1:500,000, 17 p. text.

Barton, G.J., Burruss, R.C., and Ryder, R.T., 1998, Water quality in the vicinity of Mosquito Creek Lake, Trumbull County, Ohio, in relation to the chemistry of locally occurring oil, natural gas, and brine: U.S. Geological Survey Water-Resources Investigations Report 98-4180, 46 p.

Bates, B.L., McIntosh, J.C., Lohse, K.A., and Brooks, P.D., 2011, Influence of groundwater flowpaths, residence times and nutrients on the extent of microbial methanogenesis in coal beds-Powder River Basin, USA: Chemical Geology, v. 284, p. 45-61. [Also available at https://doi.org/10.1016/j. chemgeo.2011.02.004.]

Bernard, B.B., Brooks, J.M., and Sackett, W.M., 1978, Light hydrocarbons in recent Texas continental shelf and slope sediments: Journal of Geophysical Research, v. 83, no. C8, p. 4053-4061. [Also available at https://doi.org/10.1029/ JC083iC08p04053.]

Botner, E.C., 2015, Elevated methane levels from biogenic coalbed gas in Ohio drinking water wells near shale gas extraction: University of Cincinnati, M.S. thesis, $31 \mathrm{p}$.
Breen, K.J., Angelo, C.G., Masters, R.W., and Sedam, A.C., 1985, Chemical and isotopic characteristics of brines from three oil- and gas-producing sandstones in Eastern Ohio, with applications to the geochemical tracing of brine sources: U.S. Geological Survey Water-Resources Investigations Report 84-4314, 58 p.

Breen, K.J., Révész, K., Baldassare, F.J., and McAuley, S.D., 2007, Natural gases in ground water near Tioga Junction, Tioga County, north-central Pennsylvania-Occurrence and use of isotopes to determine origins, 2005: U.S. Geological Survey Scientific Investigations Report 2007-5085, 65 p.

Brenton, R.W., and Arnett, T.L., 1993, Methods of analysis by the U.S. Geological Survey National Water Quality Laboratory; determination of dissolved organic carbon by UV-promoted persulfate oxidation and infrared spectrometry: U.S. Geological Survey Open-File Report 92-480, 12 p.

Burruss, R.C. and Laughrey, C.D., 2010, Carbon and hydrogen isotopic reversals in deep basin gas-Evidence for limits to the stability of hydrocarbons: Organic Geochemistry, v. 41, no. 12, p. 1285-1296. [Also available at https://doi. org/10.1016/j.orggeochem.2010.09.008.]

Chambers, D.B., Kozar, M.D., Messinger, T., Mulder, M.L., Pelak, A.J., and White, J.S., 2015, Water quality of groundwater and stream base flow in the Marcellus Shale gas field of the Monongahela River Basin, West Virginia, 2011-12 (ver. 1.1, June 25, 2015): U.S. Geological Survey Scientific Investigations Report 2014-5233, 75 p. [Also available at https://doi.org/10.3133/sir20145233.]

Churchill, S.E., 2000, Qualitative estimate of recharge in an unconsolidated glacial aquifer in Fulton County, Ohio: Ohio State University, B.S. Thesis, Geological Sciences 18 p.

Clark, I., and Fritz, P., 1997, Environmental isotopes in hydrogeology: New York, Lewis Publishers, 328 p.

Coleman, D.D., Liu, C.L., and Riley, K.M., 1988, Microbial methane in the shallow Paleozoic sediments and glacial deposits of Illinois, U.S.A: Chemical Geology, v. 71, no. 1-3, p. 23-40. [Also available at https://doi. org/10.1016/0009-2541(88)90103-9.]

Coleman, D.D., Liu, C.L., Hackley, K.C., and Pelphrey, S.R., 1995, Isotopic identification of landfill methane: Environmental Geoscience, v. 2, no. 2, p. 95-103.

Coogan, A.H., 1996, Ohio's surface rocks and sediments, in Feldmann, R. M., and Hackathorn, Merrianne, eds., Fossils of Ohio: Ohio Division of Geological. Survey Bulletin 70, p. 31-50, accessed February 24, 2018, at http://geosurvey.ohiodnr.gov/portals/geosurvey/PDFs/Misc_State Maps\&Pubs/OH_SurfaceRocks_Sediments.pdf. 
Craig, H., 1961, Isotopic variations in meteoric waters: Science, v. 133, no. 3465, p. 1702-1703. [Also available at https://doi.org/10.1126/science.133.3465.1702.]

Darrah, T.H., Jackson, R.B., Vengosh, Avner, Warner, R., Whyte, C.J., Walsh, T.B., Kondash, A.J., and Poreda, R.J., 2015, The evolution of Devonian hydrocarbon gases in shallow aquifers of the northern Appalachian BasinInsights from integrating noble gas and hydrocarbon geochemistry: Geochimica et Cosmochimica Acta, v. 170, p. 321-355. [Also available at https://doi.org/10.1016/j. gca.2015.09.006.]

East, J.A., Swezey, C.S., Repetski, J.E., and Hayba, D.O., 2012, Thermal maturity map of Devonian shale in the Illinois, Michigan, and Appalachian basins of North America: U.S. Geological Survey Scientific Investigations Map 3214, 1 sheet.

Eberts, S.M., and George, L.L., 2000, Regional ground-water flow and geochemistry in the Midwestern basins and arches aquifer system in parts of Indiana, Ohio, Michigan, and Illinois: U.S. Geological Survey Professional Paper 1423C, $103 \mathrm{p}$.

Eltschlager, K.K., Hawkins, J.W., Ehler, W.C., and Baldassare, F., 2001, Technical measures for the investigation and mitigation of fugitive methane hazards for areas of coal mining: U.S. Department of the Interior, Office of Surface Mining Reclamation and Enforcement, 125 p., accessed June 9, 2017, at https:/www.osmre.gov/resources/library/ ghm/methane.pdf.

Fishman, M.J., ed., 1993, Methods of analysis by the U.S. Geological Survey National Water Quality Laboratory; determination of inorganic and organic constituents in water and fluvial sediments: U.S. Geological Survey Open-File Report 93-125, 217 p.

Garbarino, J.R., Lewis, M.J., and Bednar, A.J., 2012, Arsenic speciation (ver. 2.1): U.S. Geological Survey Techniques of Water-Resources Investigations, book 9, chap. A5, sec. 5.6.4.A, 7 p.

Golding, S.D., Boreham, C.J., and Esterle, J.S., 2013, Stable isotope geochemistry of coal bed and shale gas and related production waters-A review: International Journal of Coal Geology, v. 120, p. 24-40. [Also available at https://doi. org/10.1016/j.coal.2013.09.001.]

Harkness, J.S., Darrah, T.H., Warner, N.R., Whyte, C.J., Moore, M.T., Millot, R., Kloppmann, W., Jackson, R.B., and Vengosh, A., 2017, The geochemistry of naturally occurring methane and saline groundwater in an area of unconventional shale gas development: Geochimica et Cosmochimica Acta, v. 208, p. 302-334. [Also available at https://doi.org/10.1016/j.gca.2017.03.039.]
Heisig, P.M., and Scott, T.M., 2013, Occurrence of methane in groundwater of south-central New York State, 2012-systematic evaluation of a glaciated region by hydrogeologic setting: U.S. Geological Survey Scientific Investigations Report 2013-5190, 32 p. [Also available at https://pubs. usgs.gov/sir/2013/5190/.]

Hem, J.D., 1992, Study and interpretation of chemical characteristics of natural water: U.S. Geological Survey Water-Supply Paper 2254, 263 p.

Hinrichs, K.U., Hayes, J.M., Bach, W., Spivack, A.J., Hmelo, L.R., Holm, N.G., Johnson, C.G., and Sylva, S.P., 2006, Biological formation of ethane and propane in the deep marine subsurface: Proceedings of the National Academy of Sciences of the United States of America, v. 103, no. 40, p. 14684-14689. [Also available at https://doi.org/10.1073/ pnas.0606535103.]

Isotech Laboratories, Inc., 2014, Collection of ground water samples from domestic and municipal water wells for dissolved gas analysis using IsoBags ${ }^{\circledR}$ : Isotech Laboratories, Inc., product information sheet, accessed March 18, 2018, at http://www.isotechlabs.com/customersupport/samplingprocedures/IsoBagSM.pdf.

Jackson, R.B., Vengosh, Avner, Darrah, T.H., Warner, N.R., Down, Adrian, Poreda, R.J., Osborn, S.G., Zhao, Kaiguang, and Karr, J.D., 2013, Increased stray gas abundance in a subset of drinking water wells near Marcellus shale gas extraction: Proceedings of the National Academy of Sciences, v. 110, no. 28, p. 11250-11255. [Also available at https://doi.org/10.1073/pnas.1221635110.]

Jenden, P.D., Drazan, D.J., and Kaplan, I.R., 1993, Mixing of thermogenic natural gases in northern Appalachian basin: The American Association of Petroleum Geologists Bulletin, v. 77, no. 6, p. 980-998.

Kendall, C., and Coplen, T.B., 2001, Distribution of oxygen-18 and deuterium in river waters across the United States: Hydrological Processes, v. 15, no. 7, p. 1363-1393. [Also available at https://doi.org/10.1002/hyp.217.]

Laughrey, C.D., and Baldassare, F.J., 1998, Geochemistry and origin of some natural gases in the Plateau Province, central Appalachian Basin, Pennsylvania and Ohio: The American Association of Petroleum Geologists Bulletin, v. 82, no. 2, p. 317-335.

Martini, A.M., Walter, L.M., Budai, J.M., Ku, T.C.W., Kasier, C.J., and Schoell, M., 1998, Genetic and temporal relations between formation waters and biogenic methane-Upper Devonian Antrim Shale, Michigan Basin: Geochimica et Cosmochimica Acta, v. 62, no. 10, p. 1699-1720. [Also available at https://doi.org/10.1016/S0016-7037(98)00090-8.] 
Martini, A.M., Walter, L.M., Ku, T.C.W., Budai, J.M., McIntosh, J.C., and Schoell, M., 2003, Microbial production and modification of gases in sedimentary basins-A geochemical case study from a Devonian shale gas play, Michigan Basin: The American Association of Petroleum Geologists Bulletin, v. 87, no. 8, p. 1355-1375. [Also available at https://doi.org/10.1306/031903200184.]

McIntosh, J.C., Walter, L.M., and Martini, A.M., 2002, Pleistocene recharge to midcontinent basins-Effects on salinity structure and microbial gas generation: Geochimica et Cosmochimica Acta, v. 66, no. 10, p. 1681-1700. [Also available at https://doi.org/10.1016/S0016-7037(01)00885-7.]

Molofsky, L.J., Connor, J.A., Wylie, A.S., Jr., Wagner, T., and Farhat, S.K., 2013, Evaluation of methane sources in groundwater in northeastern Pennsylvania: Groundwater, v. 51, no. 3, p. 333-349. [Also available at https://doi. org/10.1111/gwat.12056.]

Ohio Department of Natural Resources, Division of Geological Survey, 2004a, Oil and gas fields map of Ohio: Ohio Division of Geological Survey Map PG-1, generalized page-size version with text, 2 p., scale 1:2,000,000.

Ohio Department of Natural Resources, Division of Geological Survey, 2004b, Shaded drift-thickness map of Ohio: Ohio Division of Geological Survey Map SG-3 2004, item no. CDROMSG3, scale 1:5,000,000.

Osborn, S.G., and McIntosh, J.C., 2010, Chemical and isotopic tracers of the contribution of microbial gas in Devonian organic-rich shales and reservoir sandstone, northern Appalachian Basin: Applied Geochemistry, v. 25, no. 3, p. 456-471. [Also available at https://doi.org/10.1016/j.apgeochem.2010.01.001.]

Osborn, S.G., Vengosh, A., Warner, N.R., and Jackson, R.B., 2011, Methane contamination of drinking water accompanying gas-well drilling and hydraulic fracturing: Proceedings of the National Academy of Sciences, v. 108, no. 20, p. 8172-8176. [Also available at https://doi.org/10.1073/ pnas.1100682108.]

Plummer, N., Bexfield, L.M., Anderholm, S. K., Sanford, W.E., and Busenberg, E., 2004, Geochemical characterization of ground-water flow in the Santa Fe Group aquifer system, Middle Rio Grande Basin, New Mexico: U.S. Geological Survey Water-Resources Investigations Report 2003-4131, 395 p.

Révész, K.M., Breen, K.J., Baldassare, A.J., and Burruss, R.C., 2012, Carbon and hydrogen isotopic evidence for the origin of combustible gases in water-supply wells in northcentral Pennsylvania: Applied Geochemistry, v. 27, no. 1, p. 361-375. [Also available at https://doi.org/10.1016/j. apgeochem.2011.12.002.]
Schegel, M.E., McIntosh, J.C., Bates, B.L., Kirk, M.F., and Martini, A.M., 2011, Comparison of fluid geochemistry and microbiology of multiple organic-rich reservoirs in the Illinois Basin, USA - Evidence for controls on methanogenesis and microbial transport: Geochimica et Cosmochimica Acta, v. 75, no. 7, p. 1903-1919. [Also available at https:// doi.org/10.1016/j.gca.2011.01.016.]

Schoell, M., 1980, The hydrogen and carbon isotopic composition of methane from natural gases of various origins: Geochimica et Cosmochimica Acta, v. 44, no. 5, p. 649-661. [Also available at https://doi.org/10.1016/00167037(80)90155-6.]

Schoell, M., 1988, Multiple origins of methane in the Earth: Chemical Geology, v. 71, no. 1-3, p. 1-10. [Also available at https://doi.org/10.1016/0009-2541(88)90101-5.]

Senior, L.A., Cravotta, C.A., III, and Sloto, R.A., 2016, Baseline assessment of groundwater quality in Wayne County, Pennsylvania, 2014: U.S. Geological Scientific Investigations Report 2016-5073, 136 p. [Also available at https:// doi.org/10.3133/sir20165073.]

Sharma, S., Mulder, M.L., Sack, A., Schroeder, K., and Hammack, R., 2014, Isotope approach to assess hydrologic connections during Marcellus Shale drilling: Groundwater, v. 52, no. 3, p. 424-433. [Also available at https://doi. org/10.1111/gwat.12083.]

Sharma, S., Bowman, L., Schroeder, K., and Hammack, R., 2015, Assessing changes in gas migration pathways at a hydraulic fracturing site-Example from Greene County, Pennsylvania, USA: Applied Geochemistry, v. 60, p. 51-58. [Also available at https://doi.org/10.1016/j.apgeochem.2014.07.018.]

Slucher, E.R., Swinford, E.M., Larsen, G.E., Schumacher, G.A., Shrake, D.L., Rice, C.L., Caudill, M.R., Rea, R.G., and Powers, D.M., 2006, Bedrock geologic map of Ohio (ver. 6.0): Ohio Division of Geological Survey Map BG-1, scale 1:500,000.

Strapoc, D., Mastalerz, M., Eble, C., and Schimmelmann, A., 2007, Characterization of the origin of coalbed gases in southeastern Illinois Basin by compound-specific carbon and hydrogen stable isotope ratios: Organic Geochemistry, v. 38, no. 2, p. 267-287. [Also available at https://doi. org/10.1016/j.orggeochem.2006.09.005.]

U.S. Geological Survey, variously dated, National field manual for the collection of water-quality data: U.S. Geological Survey Techniques of Water-Resources Investigations, book 9, chaps. A1-A9, accessed January 23, 2016, at https://pubs. er.usgs.gov/usgspubs/twri/twri09. 
U.S. Geological Survey, 2016a, Dissolved gas analysis: U.S. Geological Survey web page, accessed March 23, 2018, at https://water.usgs.gov/lab/dissolved-gas/lab/analytical_procedures/.

U.S. Geological Survey, 2016b, Dissolved gas sampling instructions - Collection and analysis of ground-water samples for helium by gas chromatography: U.S. Geological Survey web page, accessed March 23, 2018, at https:// water.usgs.gov/lab/dissolved-gas/sampling/\#hel.

U.S. Geological Survey, 2018, National Water Information System-Web interface, accessed June 12, 2018, at https:// doi.org/10.5066/F7P55KJN.

Vinson, D.S., Blair, N.E., and Martini, A.M., Larter, S., Orem, W.H., and McIntosh, J.C., 2017, Microbial methane from in situ biodegradation of coal and shale-A review and reevaluation of hydrogen and carbon isotope signatures: Chemical Geology, v. 453, no. 20, p. 128-145. [Also available at https://doi.org/10.1016/j.chemgeo.2017.01.027.]

Waldron, S., Lansdown, J.M., Scott, E.M., Fallick, A.E., and Hall, A.J., 1999, The global influence of the hydrogen isotope composition of water on that of bacteriogenic methane from shallow freshwater environments: Geochimica et Cosmochimica Acta, v. 63, no. 15, p. 2237-2245. [Also available at https://doi.org/10.1016/S0016-7037(99)00192-1.]
Warner, N.R., Jackson, R.B., Darrah, T.H., Osborn, S.G., Down, A., Zhao, K., White, A., and Vengosh, A., 2012, Geochemical evidence for possible natural migration of Marcellus Formation brine to shallow aquifers in Pennsylvania: Proceedings of the National Academy of Sciences, v. 109, no. 30, p. 11961-11966. [Also available at https://doi. org/10.1073/pnas.1121181109.]

Whiticar, M.J., 1999, Carbon and hydrogen isotope systematics of bacterial formation and oxidation of methane: Chemical Geology, v. 161, no. 1-3, p. 291-314. [Also available at https://doi.org/10.1016/S0009-2541(99)00092-3.]

Whiticar, M.J., Faber, E., and Schoell, M., 1986, Biogenic methane formation in marine and freshwater environments - $\mathrm{CO}_{2}$ reduction vs. acetate fermentation-Isotopic evidence: Geochimica et Cosmochimica Acta, v. 50, no. 5, p. 693-709. [Also available at https://doi.org/10.1016/00167037(86)90346-7.] 
Tables 2, 3, and 5 
Table 2. Results of quality-control samples analyzed at U.S. Geological Survey National Water Quality Laboratory.

[mg/L, milligrams per liter; --, no data; <, less than; N, nitrogen; nd, no difference; P, phosphorus; $\mu \mathrm{g} / \mathrm{L}$, micrograms per liter; As, arsenic]

\begin{tabular}{|c|c|c|c|c|c|c|c|c|c|c|c|c|}
\hline \multirow{3}{*}{$\begin{array}{l}\text { Sample type } \\
\text { Date } \\
\text { Time }\end{array}$} & \multirow{3}{*}{$\begin{array}{c}\begin{array}{c}\text { Equipment } \\
\text { blank }\end{array} \\
5 / 31 / 2016 \\
1503,1505\end{array}$} & \multicolumn{2}{|c|}{ Field blank } & \multicolumn{3}{|c|}{ Replicate } & \multicolumn{3}{|c|}{ Replicate } & \multicolumn{3}{|c|}{ Replicate } \\
\hline & & \multirow{2}{*}{$\begin{array}{c}6 / 15 / 2016 \\
1106\end{array}$} & \multirow{2}{*}{$\begin{array}{c}6 / 20 / 2016 \\
1206\end{array}$} & \multicolumn{2}{|c|}{$6 / 2 / 2016$} & \multirow{2}{*}{$\begin{array}{c}\text { Percent } \\
\text { difference }\end{array}$} & \multicolumn{2}{|c|}{ 6/16/2016 } & \multirow{2}{*}{$\begin{array}{c}\text { Percent } \\
\text { difference }\end{array}$} & \multicolumn{2}{|c|}{$6 / 21 / 2016$} & \multirow{2}{*}{$\begin{array}{c}\text { Percent } \\
\text { difference }\end{array}$} \\
\hline & & & & 1100 & 1101 & & 1100 & 1101 & & 1000 & 1001 & \\
\hline \multicolumn{13}{|l|}{ Constituent } \\
\hline Dissolved solids (mg/L) & -- & $<20$ & -- & -- & -- & -- & -- & -- & -- & -- & -- & -- \\
\hline Calcium (mg/L) & -- & $<0.022$ & -- & -- & -- & -- & -- & -- & -- & -- & -- & -- \\
\hline Magnesium (mg/L) & -- & $<0.011$ & -- & -- & -- & -- & -- & -- & -- & -- & -- & -- \\
\hline Potassium $(\mathrm{mg} / \mathrm{L})$ & -- & $<0.03$ & -- & -- & -- & -- & -- & -- & -- & -- & -- & -- \\
\hline Sodium (mg/L) & -- & $<0.06$ & -- & -- & -- & -- & -- & -- & -- & -- & -- & -- \\
\hline Bromide (mg/L) & -- & $<0.01$ & -- & -- & -- & -- & -- & -- & -- & -- & -- & -- \\
\hline Chloride (mg/L) & -- & $<0.02$ & -- & -- & -- & -- & -- & -- & -- & -- & -- & -- \\
\hline Fluoride $(\mathrm{mg} / \mathrm{L})$ & -- & $<0.01$ & -- & -- & -- & -- & -- & -- & -- & -- & -- & -- \\
\hline Silica $(\mathrm{mg} / \mathrm{L})$ & -- & $<0.018$ & -- & -- & -- & -- & -- & -- & -- & -- & -- & -- \\
\hline Total nitrogen (mg/L) & -- & $<0.05$ & -- & -- & -- & -- & -- & -- & -- & 0.50 & 0.52 & 3.9 \\
\hline Ammonia (mg/L as $\mathrm{N})$ & -- & $<0.01$ & -- & -- & -- & -- & -- & -- & -- & 0.40 & 0.39 & 3.3 \\
\hline Nitrite (mg/L as N) & -- & $<0.001$ & -- & -- & -- & -- & -- & -- & -- & $<0.001$ & $<0.001$ & nd \\
\hline Orthophosphate (mg/L as $\mathrm{P})$ & -- & $<0.004$ & -- & -- & -- & -- & -- & -- & -- & 0.038 & 0.039 & \\
\hline Nitrate+Nitrile (mg/L as N) & -- & $<0.04$ & -- & -- & -- & -- & -- & -- & -- & $<0.040$ & $<0.040$ & nd \\
\hline Aluminum $(\mu \mathrm{g} / \mathrm{L})$ & $<3$ & -- & -- & $<3$ & $<3$ & nd & -- & -- & -- & -- & & \\
\hline Antimony $(\mu \mathrm{g} / \mathrm{L})$ & $<0.027$ & -- & -- & $<0.027$ & $<0.027$ & nd & -- & -- & -- & -- & -- & -- \\
\hline $\operatorname{Barium}(\mu \mathrm{g} / \mathrm{L})$ & $<0.25$ & -- & -- & 523 & 511 & & -- & -- & -- & -- & -- & -- \\
\hline Beryllium $(\mu \mathrm{g} / \mathrm{L})$ & $<0.020$ & -- & -- & $<0.020$ & $<0.020$ & nd & -- & -- & -- & -- & -- & -- \\
\hline Cadmium $(\mu \mathrm{g} / \mathrm{L})$ & $<0.030$ & -- & -- & $<0.030$ & $<0.030$ & nd & -- & -- & -- & -- & -- & -- \\
\hline Lead $(\mu \mathrm{g} / \mathrm{L})$ & $<0.040$ & -- & -- & $<0.040$ & $<0.040$ & nd & -- & -- & -- & -- & -- & -- \\
\hline Iron $(\mu \mathrm{g} / \mathrm{L})$ & & -- & -- & & & & -- & -- & -- & -- & -- & -- \\
\hline Manganese $(\mu \mathrm{g} / \mathrm{L})$ & $<0.4$ & -- & -- & 39.7 & 39.3 & 1.0 & -- & -- & -- & -- & -- & -- \\
\hline Molybdenum ( $\mu \mathrm{g} / \mathrm{L})$ & $<0.05$ & -- & -- & 0.216 & 0.196 & 9.7 & -- & -- & -- & -- & -- & -- \\
\hline Silver $(\mu \mathrm{g} / \mathrm{L})$ & $<0.020$ & -- & -- & $<0.020$ & $<0.020$ & nd & -- & -- & -- & -- & -- & -- \\
\hline Uranium $(\mu \mathrm{g} / \mathrm{L})$ & $<0.0140$ & -- & -- & $<0.0140$ & $<0.0140$ & nd & -- & -- & -- & -- & -- & -- \\
\hline Boron $(\mu \mathrm{g} / \mathrm{L})$ & $<5$ & -- & -- & 112 & 109 & 2.7 & -- & -- & -- & -- & -- & -- \\
\hline Lithium $(\mu \mathrm{g} / \mathrm{L})$ & $<0.22$ & -- & -- & 0.981 & 0.824 & 17 & -- & -- & -- & -- & -- & -- \\
\hline
\end{tabular}


Table 2. Results of quality-control samples analyzed at U.S. Geological Survey National Water Quality Laboratory.-Continued

$[\mathrm{mg} / \mathrm{L}$, milligrams per liter; --, no data; <, less than; N, nitrogen; nd, no difference; P, phosphorus; $\mu \mathrm{g} / \mathrm{L}$, micrograms per liter; As, arsenic]

\begin{tabular}{|c|c|c|c|c|c|c|c|c|c|c|c|c|}
\hline \multirow{3}{*}{$\begin{array}{l}\text { Sample type } \\
\text { Date } \\
\text { Time }\end{array}$} & \multirow{3}{*}{$\begin{array}{c}\begin{array}{c}\text { Equipment } \\
\text { blank }\end{array} \\
5 / 31 / 2016 \\
1503,1505\end{array}$} & \multicolumn{2}{|c|}{ Field blank } & \multicolumn{3}{|c|}{ Replicate } & \multicolumn{3}{|c|}{ Replicate } & \multicolumn{3}{|c|}{ Replicate } \\
\hline & & \multirow{2}{*}{$\begin{array}{c}6 / 15 / 2016 \\
1106\end{array}$} & \multirow{2}{*}{$\begin{array}{c}6 / 20 / 2016 \\
1206\end{array}$} & \multicolumn{2}{|c|}{$6 / 2 / 2016$} & \multirow{2}{*}{$\begin{array}{c}\text { Percent } \\
\text { difference }\end{array}$} & \multicolumn{2}{|c|}{ 6/16/2016 } & \multirow{2}{*}{$\begin{array}{c}\text { Percent } \\
\text { difference }\end{array}$} & \multicolumn{2}{|c|}{ 6/21/2016 } & \multirow{2}{*}{$\begin{array}{l}\text { Percent } \\
\text { difference }\end{array}$} \\
\hline & & & & 1100 & 1101 & & 1100 & 1101 & & 1000 & 1001 & \\
\hline \multicolumn{13}{|l|}{ Constituent } \\
\hline Strontium $(\mu \mathrm{g} / \mathrm{L})$ & $<0.8$ & -- & -- & 1,270 & 1,260 & 0.8 & -- & -- & -- & -- & -- & -- \\
\hline Thallium $(\mu \mathrm{g} / \mathrm{L})$ & $<0.03$ & -- & -- & $<0.030$ & $<0.030$ & nd & -- & -- & -- & -- & -- & -- \\
\hline Arsenic $(\mu \mathrm{g} / \mathrm{L})$ & $<0.1$ & -- & -- & 39.5 & 39.7 & 0.5 & -- & -- & -- & -- & -- & -- \\
\hline Cobalt $(\mu \mathrm{g} / \mathrm{L})$ & $<0.05$ & -- & -- & 0.381 & 0.376 & 1.3 & -- & -- & -- & -- & -- & -- \\
\hline Chromium $(\mu \mathrm{g} / \mathrm{L})$ & $<0.3$ & -- & -- & 0.37 & 0.37 & nd & -- & -- & -- & -- & -- & -- \\
\hline Copper $(\mu \mathrm{g} / \mathrm{L})$ & $<0.80$ & -- & -- & $<0.80$ & $<0.80$ & nd & -- & -- & -- & -- & -- & -- \\
\hline Nickel $(\mu \mathrm{g} / \mathrm{L})$ & $<0.2$ & -- & -- & 0.656 & 0.665 & 1.4 & -- & -- & -- & -- & -- & -- \\
\hline Selenium $(\mu \mathrm{g} / \mathrm{L})$ & $<0.05$ & -- & -- & 0.079 & 0.090 & 13 & -- & -- & -- & -- & -- & -- \\
\hline Vanadium $(\mu \mathrm{g} / \mathrm{L})$ & $<0.1$ & -- & -- & 0.75 & 0.75 & nd & -- & -- & -- & -- & -- & -- \\
\hline $\operatorname{Zinc}(\mu \mathrm{g} / \mathrm{L})$ & $<2$ & -- & -- & 20.8 & 37.4 & 57 & -- & -- & -- & -- & -- & -- \\
\hline Organic carbon $(\mathrm{mg} / \mathrm{L})$ & $<0.23$ & -- & $<0.23$ & -- & -- & -- & 1.38 & 9.94 & 38 & -- & -- & -- \\
\hline Arsenate $(\mu \mathrm{g} / \mathrm{L}$ as As) & -- & -- & $<0.4$ & -- & -- & -- & $<0.4$ & $<0.4$ & nd & -- & -- & -- \\
\hline Arsenite $(\mu \mathrm{g} / \mathrm{L}$ as As) & -- & -- & $<0.2$ & -- & -- & -- & $<0.2$ & $<0.2$ & nd & -- & -- & -- \\
\hline $\begin{array}{l}\text { Dimethylarsinate a } \\
(\mu \mathrm{g} / \mathrm{L} \text { as As })\end{array}$ & -- & -- & $<0.3$ & -- & -- & -- & $<0.3$ & $<0.3$ & nd & -- & -- & -- \\
\hline $\begin{array}{l}\text { Monomethylarsonate } \\
\quad(\mu \mathrm{g} / \mathrm{L} \text { as As })\end{array}$ & -- & -- & $<0.8$ & -- & -- & -- & $<0.8$ & $<0.8$ & nd & -- & -- & -- \\
\hline
\end{tabular}


Table 3. Results of quality-control samples analyzed at Isotech Laboratories and U.S. Geological Survey Reston Groundwater Dating Laboratory.

[USGS, U.S. Geological Survey; <, less than; nd, no difference; --, no data; C, carbon; mg/L, milligram per liter; $\delta$, isotopic ratio delta notation; per mil, parts per thousand; H, hydrogen; O, oxygen; DIC, dissolved inorganic carbon]

\begin{tabular}{|c|c|c|c|c|c|c|c|c|c|c|}
\hline \multirow{3}{*}{$\begin{array}{l}\text { Sample type } \\
\text { Date } \\
\text { Time } \\
\end{array}$} & \multicolumn{3}{|c|}{ Replicate - Isotech Laboratories } & \multicolumn{3}{|c|}{ Replicate - Isotech Laboratories } & \multicolumn{3}{|c|}{$\begin{array}{c}\text { Replicate - USGS Groundwater } \\
\text { Dating Laboratory }\end{array}$} & \multirow{3}{*}{$\begin{array}{c}\begin{array}{c}\text { Lab split } \\
\text { samples }\end{array} \\
\text { 6/21/201t }\end{array}$} \\
\hline & \multicolumn{2}{|c|}{ 6/16/2016 } & \multirow{2}{*}{$\begin{array}{c}\text { Percent } \\
\text { difference }\end{array}$} & \multicolumn{2}{|c|}{ 6/21/2016 } & \multirow{2}{*}{$\begin{array}{c}\text { Percent } \\
\text { difference }\end{array}$} & \multicolumn{2}{|c|}{$6 / 21 / 2016$} & \multirow{2}{*}{$\begin{array}{c}\text { Percent } \\
\text { difference }\end{array}$} & \\
\hline & 1100 & 1101 & & 1000 & 1011 & & 1000 & 1011 & & \\
\hline \multicolumn{11}{|l|}{ Constituent } \\
\hline Oxygen, mole percent & 0.66 & 0.75 & 13 & 1.06 & 0.99 & 6.8 & $<0.02$ & $<0.02$ & nd & $>190$ \\
\hline Carbon dioxide, mole percent & 1.07 & 1.06 & 0.9 & 0.98 & 0.97 & 1.0 & 12.85 & 12.25 & 4.8 & 171 \\
\hline Carbon monoxide, mole percent & $<0.01$ & $<0.01$ & nd & $<0.010$ & $<0.010$ & nd & -- & -- & -- & -- \\
\hline Hydrogen, mole percent & $<0.01$ & $<0.01$ & nd & $<0.010$ & $<0.010$ & nd & -- & -- & -- & -- \\
\hline Dinitrogen, mole percent & 5.39 & 5.40 & 0.2 & 7.03 & 7.23 & 2.8 & 5.20 & 5.23 & 0.006 & 31 \\
\hline Argon, mole percent & 0.131 & 0.131 & nd & 0.159 & 0.154 & 3.2 & 0.273 & 0.275 & 0.007 & 55 \\
\hline Helium, mole percent & 0.0092 & 0.0084 & 9.1 & 0.0059 & 0.0050 & 17 & -- & -- & -- & -- \\
\hline Methane, mole percent & 92.68 & 92.59 & 0.1 & 90.76 & 90.64 & 0.1 & -- & -- & -- & -- \\
\hline Ethane, mole percent & 0.0571 & 0.0570 & 0.2 & 0.0090 & 0.0091 & 1.1 & -- & -- & -- & -- \\
\hline Ethene, mole percent & $<0.0001$ & $<0.0001$ & nd & $<0.0001$ & $<0.0001$ & nd & -- & -- & -- & -- \\
\hline Propane, mole percent & 0.0001 & 0.0001 & nd & $<0.0001$ & $<0.0001$ & nd & -- & -- & -- & -- \\
\hline n-Pentane, mole percent & $<0.0001$ & $<0.0001$ & nd & $<0.0001$ & $<0.0001$ & nd & -- & -- & -- & -- \\
\hline Propene, mole percent & $<0.0001$ & $<0.0001$ & nd & $<0.0001$ & $<0.0001$ & nd & -- & -- & -- & -- \\
\hline 2-Methylpropane, mole percent & $<0.0001$ & $<0.0001$ & nd & $<0.0001$ & $<0.0001$ & nd & -- & -- & -- & -- \\
\hline Butane, mole percent & $<0.0001$ & $<0.0001$ & nd & $<0.0001$ & $<0.0001$ & nd & -- & -- & -- & -- \\
\hline n-Butane, mole percent & $<0.0001$ & $<0.0001$ & nd & $<0.0001$ & $<0.0001$ & nd & -- & -- & -- & -- \\
\hline 2-Methylbutane, mole percent & $<0.0001$ & $<0.0001$ & nd & $<0.0001$ & $<0.0001$ & nd & -- & -- & -- & -- \\
\hline $\mathrm{C}_{6+}$ hydrocarbons, mole percent & $<0.0001$ & $<0.0001$ & nd & $<0.0001$ & $<0.0001$ & nd & -- & -- & -- & -- \\
\hline Methane, mg/L & 120 & 120 & nd & 91 & 91 & nd & 68.18 & 67.08 & 0.016 & 29 \\
\hline Ethane, $\mathrm{mg} / \mathrm{L}$ & 0.14 & 0.14 & nd & 0.0180 & 0.018 & nd & -- & -- & -- & -- \\
\hline Propane, mg/L & 0.0003 & 0.0004 & 29 & $<0.0002$ & $<0.0002$ & nd & -- & -- & -- & -- \\
\hline$\delta^{13} \mathrm{C}$ in methane, per mil & -62.46 & -62.40 & -0.1 & -- & -- & -- & -- & -- & -- & -- \\
\hline$\delta^{2} \mathrm{H}$ in methane, per mil & -241.9 & -241.9 & nd & -- & -- & -- & -- & -- & -- & -- \\
\hline$\delta^{18} \mathrm{O}$ in water, per mil & -8.69 & -8.55 & -1.6 & -- & -- & -- & -- & -- & -- & -- \\
\hline$\delta^{2} \mathrm{H}$ in water, per mil & -57.3 & -56.4 & -1.6 & -- & -- & -- & -- & -- & -- & -- \\
\hline$\delta^{13} \mathrm{C}$ of DIC in water, per mil & 10.8 & 8.2 & 27 & -- & -- & -- & -- & -- & -- & -- \\
\hline${ }^{14} \mathrm{C}$ of methane, percent modern carbon & $<0.4$ & $<0.4$ & nd & -- & -- & -- & -- & -- & -- & -- \\
\hline
\end{tabular}

${ }^{1}$ Percent difference was calculated using the average value of two replicates from each laboratory. 
Table 5. Water-quality data from Ohio domestic wells, 2016.

[mm Hg, millimeters mercury; --, no data; $\mathrm{mg} / \mathrm{L}$, milligrams per liter; $\mu \mathrm{g} / \mathrm{L}$, micrograms per liter; BLS, below land surface; $\mu \mathrm{S} / \mathrm{cm}$, microsiemens per centimeter; NTRU, nephelometric turbidity ratio unit; $\mathrm{U}$, hydrogen sulfide odor not detected; $\mathrm{M}$, hydrogen sulfide odor detected; $\mathrm{CaCO}_{3}$, calcium carbonate; $\mathrm{N}$, nitrogen; <, less than; As, arsenic; DIC, dissolved inorganic carbon; $\mathrm{CH}_{4}$, methane; $\mathrm{H}_{2} \mathrm{O}$, water;

$\mathrm{O}$, oxygen; $\delta$, isotopic ratio delta notation; per mil, parts per thousand]

\begin{tabular}{|c|c|c|c|c|c|c|c|c|c|c|c|c|c|}
\hline $\begin{array}{c}\text { Well } \\
\text { identifier }\end{array}$ & $\begin{array}{c}\text { Date } \\
\text { (yyyymmdd) }\end{array}$ & $\begin{array}{c}\text { Barometric } \\
\text { pressure } \\
(\mathrm{mm} \mathrm{Hg})\end{array}$ & $\begin{array}{c}\text { Air } \\
\text { temperature } \\
\text { (degrees } \\
\text { Celsius) }\end{array}$ & $\begin{array}{c}\text { Water } \\
\text { level } \\
\text { (ft BLS) }\end{array}$ & $\begin{array}{l}\text { Dissolved } \\
\text { oxygen } \\
\text { (mg/L) }\end{array}$ & $\begin{array}{c}\text { pH } \\
\text { (standard } \\
\text { units) }\end{array}$ & $\begin{array}{c}\text { Specific } \\
\text { conductance } \\
\text { (uS/cm) }\end{array}$ & $\begin{array}{l}\text { Water } \\
\text { temperature } \\
\text { (degrees } \\
\text { Celsius) }\end{array}$ & $\begin{array}{l}\text { Turbidity } \\
\text { (NTRU) }\end{array}$ & $\begin{array}{c}\text { Altitude } \\
\text { of land } \\
\text { surface } \\
\text { (ft above } \\
\text { NAVD88) }\end{array}$ & $\begin{array}{c}\text { Well } \\
\text { depth } \\
\text { (ft BLS) }\end{array}$ & $\begin{array}{l}\text { Hydrogen } \\
\text { sulfide } \\
\text { odor }\end{array}$ & $\begin{array}{c}\text { Alkalinity, } \\
\text { mg/L as } \\
\mathrm{CaCO}_{3}\end{array}$ \\
\hline AB-142 & 20160614 & 735 & 27 & 9.75 & 1.2 & 8.7 & 735 & 11.8 & 0.2 & 1,080 & 94 & $\mathrm{U}$ & 375 \\
\hline GE-368 & 20160614 & 731 & 27 & 61.19 & 0.2 & 9 & 1120 & 11.9 & 0.1 & 1,137 & 150 & M & 320 \\
\hline SU-23 & 20160615 & 729 & 24 & -- & 0.3 & 7.4 & 835 & 12.5 & 0.3 & 1,115 & 95 & $\mathrm{U}$ & 353 \\
\hline ST-140 & 20160613 & 738 & 24 & 69.87 & 0.2 & 7.5 & 587 & 12.5 & 3 & 1,058 & 295 & M & 278 \\
\hline ST-139 & 20160613 & -- & 27 & 21.65 & 0.2 & 8.2 & 1880 & 13.9 & 59 & 978 & 235 & M & 454 \\
\hline ST-141 & 20160616 & 735 & 27 & 31.1 & 0.2 & 7.7 & 5030 & 12.7 & 1 & 1,104 & 301 & $\mathrm{U}$ & 442 \\
\hline CO-31 & 20160615 & 729 & 27 & -- & 0.3 & 8.1 & 1940 & 15.4 & 0.2 & 1,192 & 345 & M & 889 \\
\hline PE-59 & 20160601 & 738 & 29 & 54.02 & 0.2 & 8 & -- & 12.5 & 5.3 & 873 & 190 & M & 359 \\
\hline MU-128 & 20160601 & -- & 32 & 85.86 & 0.2 & 8.1 & -- & 14.2 & 8.9 & 866 & 263 & $\mathrm{U}$ & 452 \\
\hline GR-755 & 20160602 & 742 & 26 & -- & 0.2 & 7.1 & -- & 13.5 & 2 & 857 & 171 & M & 581 \\
\hline MT-1286 & 20160602 & 740 & 27 & 24.21 & 0.2 & 7 & -- & 13.7 & 25 & 899 & 300 & $\mathrm{U}$ & 393 \\
\hline DE-28 & 20160620 & 744 & 32 & 24.33 & 0.3 & 7.7 & 543 & 15.3 & 3.6 & 716 & 93 & $\mathrm{U}$ & 225 \\
\hline DE-29 & 20160621 & 748 & 27 & 47.75 & 0.2 & 7.5 & 641 & 13.4 & 0.2 & 736 & 144 & $\mathrm{U}$ & 278 \\
\hline HY-53 & 20160620 & 746 & 32 & 51.83 & 0.2 & 7.9 & 743 & 14 & 5.4 & 738 & 128 & $\mathrm{U}$ & 252 \\
\hline CR-63 & 20160621 & 732 & 27 & 26.64 & 0.2 & 7.4 & 985 & 14 & 2.1 & 1,011 & 75 & $\mathrm{U}$ & 339 \\
\hline
\end{tabular}


Table 5. Water-quality data from Ohio domestic wells, 2016.-Continued

[yyyymmdd, date in year-month-day format; mm Hg, millimeters mercury; ft, feet; BLS, below land surface; mg/L, milligrams per liter; $\mu \mathrm{S} / \mathrm{cm}$, microsiemens per centimeter; NTRU, nephelometric turbidity ratio unit; NAVD 88, North American Vertical Datum of 1988; $\mathrm{CaCO}_{3}$, calcium carbonate; U, hydrogen sulfide odor not detected; M, hydrogen sulfide odor detected; --, no data; N, nitrogen; $\mathrm{P}$, phosphorus; $<$, less than; As, arsenic; $\delta$, isotopic ratio delta notation; $\mathrm{C}$, carbon; DIC, dissolved inorganic carbon; per mil, parts per thousand; $\mathrm{CH}_{4, \text { methane }} ; \mathrm{H}$, hydrogen; $\mathrm{H}_{2} \mathrm{O}$, water; $\mathrm{O}$, oxygen]

\begin{tabular}{|c|c|c|c|c|c|c|c|c|c|c|c|c|c|c|}
\hline $\begin{array}{c}\text { Well } \\
\text { identifier }\end{array}$ & $\begin{array}{c}\text { Bicarbonate } \\
\text { (mg/L) }\end{array}$ & $\begin{array}{c}\text { Carbonate } \\
\text { (mg/L) }\end{array}$ & $\begin{array}{l}\text { Hydroxide } \\
\text { (mg/L) }\end{array}$ & $\begin{array}{c}\text { Sulfide } \\
\text { (mg/L) }\end{array}$ & $\begin{array}{c}\text { Dissolved } \\
\text { solids } \\
\text { (mg/L) }\end{array}$ & $\begin{array}{l}\text { Calcium } \\
\text { (mg/L) }\end{array}$ & $\begin{array}{c}\text { Magnesium } \\
\text { (mg/L) }\end{array}$ & $\begin{array}{l}\text { Potassium } \\
\text { (mg/L) }\end{array}$ & $\begin{array}{c}\text { Sodium } \\
\text { (mg/L) }\end{array}$ & $\begin{array}{c}\text { Bromide } \\
\text { (mg/L) }\end{array}$ & $\begin{array}{c}\text { Chloride } \\
\text { (mg/L) }\end{array}$ & $\begin{array}{c}\text { Fluoride } \\
\text { (mg/L) }\end{array}$ & $\begin{array}{c}\text { Silica } \\
\text { (mg/L as } \\
\mathrm{SiO}_{2} \text { ) }\end{array}$ & $\begin{array}{l}\text { Sulfate } \\
\text { (mg/L) }\end{array}$ \\
\hline AB-142 & 438 & 9.4 & 0 & 0.082 & 466 & 0.416 & 0.153 & 0.96 & 192 & 0.153 & 13.1 & 1.3 & 6.81 & 0.24 \\
\hline GE-368 & 362 & 13.9 & 0.1 & 0.073 & 645 & 2.21 & 0.697 & 1.32 & 257 & 0.922 & 60.8 & 3.33 & 7.51 & 3.56 \\
\hline SU-23 & 429 & 0.5 & 0 & 0.09 & 496 & 104 & 41.4 & 3.83 & 13.9 & 0.216 & 65.7 & 0.23 & 19.6 & 0.18 \\
\hline ST-140 & 338 & 0.4 & 0 & 0.626 & 352 & 41.5 & 12.6 & 4.62 & 82.7 & 0.139 & 17.8 & 0.42 & 7.66 & 0.03 \\
\hline ST-139 & 544 & 4.8 & 0 & 0.262 & 1,120 & 3.59 & 1.34 & 4.6 & 431 & 2.5 & 727 & 0.65 & 6.89 & 594 \\
\hline ST-141 & 535 & 1.6 & 0 & 0 & 2,940 & 25.8 & 11.1 & 6.74 & 1,060 & 8.71 & 1,350 & 0.7 & 6.99 & $<0.36$ \\
\hline $\mathrm{CO}-31$ & 1,070 & 8.4 & 0 & 0.645 & 1,240 & 3.78 & 1.51 & 3.36 & 500 & 1.03 & 117 & 1.93 & 7.02 & 5.54 \\
\hline PE-59 & 434 & 1.7 & 0 & 0.026 & 514 & 24.6 & 10.1 & 3 & 171 & 0.274 & 66 & 0.68 & 8.61 & 0.03 \\
\hline MU-128 & 543 & 4 & 0 & 0.097 & 754 & 1.87 & 0.325 & 1.13 & 296 & 0.684 & 140 & 2.46 & 7.86 & 0.11 \\
\hline GR-755 & 708 & 0.5 & 0 & 0.193 & 716 & 92.4 & 40.8 & 3.2 & 115 & 0.612 & 74.9 & 0.41 & 16.6 & 0.25 \\
\hline MT-1286 & 479 & 0.3 & 0 & 0.015 & 479 & 107 & 44.1 & 4.98 & 24.1 & 0.127 & 29.1 & 0.25 & 13.4 & 26 \\
\hline DE-28 & 274 & 0.6 & 0 & 0.001 & 318 & 28.4 & 11.8 & 2.33 & 72.3 & 0.264 & 32.2 & 1.37 & 12.4 & 0.06 \\
\hline DE-29 & 338 & 0.6 & 0 & 0.005 & 387 & 34.6 & 13.9 & 2.3 & 88.1 & 0.422 & 40.7 & 1.46 & 15.4 & 0.07 \\
\hline HY-53 & 305 & 1.1 & 0 & 0.001 & 421 & 25.2 & 11.6 & 2.43 & 122 & 0.675 & 80.8 & 1.33 & 14.2 & 0.07 \\
\hline CR-63 & 412 & 0.6 & 0 & 0.401 & 619 & 78.8 & 44.3 & 5.7 & 77.4 & 0.146 & 7.04 & 1.75 & 9.49 & 233 \\
\hline
\end{tabular}


Table 5. Water-quality data from Ohio domestic wells, 2016.-Continued

[yyyymmdd, date in year-month-day format; mm Hg, millimeters mercury; ft, feet; BLS, below land surface; mg/L, milligrams per liter; $\mu \mathrm{S} / \mathrm{cm}$, microsiemens per centimeter; NTRU, nephelometric turbidity ratio unit; NAVD 88, North American Vertical Datum of 1988; $\mathrm{CaCO}_{3}$, calcium carbonate; U, hydrogen sulfide odor not detected; M, hydrogen sulfide odor detected; --, no data; N, nitrogen; P, phosphorus; $<$, less than; As, arsenic; $\delta$, isotopic ratio delta notation; $\mathrm{C}$, carbon; DIC, dissolved inorganic carbon; per mil, parts per thousand; $\mathrm{CH}_{4}$, methane; $\mathrm{H}$, hydrogen; $\mathrm{H}_{2} \mathrm{O}$, water; $\mathrm{O}$, oxygen]

\begin{tabular}{|c|c|c|c|c|c|c|c|c|c|c|c|c|c|c|c|c|}
\hline $\begin{array}{c}\text { Well } \\
\text { identifier }\end{array}$ & $\begin{array}{c}\text { Ammonia } \\
\text { (mg/L as } \\
\mathrm{N})\end{array}$ & $\begin{array}{c}\text { Nitrate } \\
+ \text { nitrite } \\
\text { (mg/L } \\
\text { as N) }\end{array}$ & $\begin{array}{c}\text { Nitrite } \\
\text { (mg/L } \\
\text { as } N \text { ) }\end{array}$ & $\begin{array}{c}\text { Ortho- } \\
\text { phosphate } \\
\text { (mg/L as P) }\end{array}$ & $\begin{array}{c}\text { Total } \\
\text { nitrogen } \\
\text { (mg/L) }\end{array}$ & $\begin{array}{l}\text { Alum- } \\
\text { inum } \\
(\mu \mathrm{g} / \mathrm{L})\end{array}$ & $\begin{array}{c}\text { Barium } \\
\text { ( } \mu \mathrm{g} / \mathrm{L})\end{array}$ & $\begin{array}{l}\text { Beryllium } \\
\text { ( } \mu \mathrm{g} / \mathrm{L})\end{array}$ & $\begin{array}{l}\text { Cadmium } \\
\text { ( } \mu \mathrm{g} / \mathrm{L})\end{array}$ & $\begin{array}{l}\text { Chromium } \\
\text { ( } \mu \mathrm{g} / \mathrm{L})\end{array}$ & $\begin{array}{l}\text { Cobalt } \\
(\mu \mathrm{g} / \mathrm{L})\end{array}$ & $\begin{array}{l}\text { Copper } \\
(\mu \mathrm{g} / \mathrm{L})\end{array}$ & $\begin{array}{c}\text { Iron } \\
(\mu \mathrm{g} / \mathrm{L})\end{array}$ & $\begin{array}{l}\text { Lead } \\
(\mu \mathrm{g} / \mathrm{L})\end{array}$ & $\begin{array}{l}\text { Lithium } \\
\text { ( } \mu \mathrm{g} / \mathrm{L})\end{array}$ & $\begin{array}{c}\text { Manganese } \\
(\mu \mathrm{g} / \mathrm{L})\end{array}$ \\
\hline AB-142 & 0.33 & $<0.04$ & $<0.001$ & 0.093 & 0.38 & $<3$ & 2.62 & 0.05 & $<0.03$ & $<0.3$ & $<0.05$ & $<0.8$ & 7.7 & $<0.04$ & 14.2 & 0.65 \\
\hline GE-368 & 0.46 & $<0.04$ & $<0.001$ & 0.049 & 0.55 & $<3$ & 6.35 & $<0.02$ & $<0.03$ & $<0.3$ & $<0.05$ & $<0.8$ & 12.8 & $<0.04$ & 14.2 & 1.93 \\
\hline SU-23 & 0.21 & $<0.04$ & $<0.001$ & 0.009 & 0.25 & $<3$ & 1,940 & $<0.02$ & $<0.03$ & $<0.3$ & $<0.05$ & $<0.8$ & 898 & $<0.04$ & 44.2 & 86.7 \\
\hline ST-140 & 0.77 & $<0.04$ & $<0.001$ & 0.025 & 0.83 & $<3$ & 101 & 0.028 & $<0.03$ & $<0.3$ & $<0.05$ & $<0.8$ & 208 & 0.058 & 19.7 & 23.8 \\
\hline ST-139 & 0.83 & $<0.04$ & $<0.001$ & 0.102 & 0.91 & $<3$ & 307 & 0.032 & $<0.03$ & $<0.3$ & $<0.05$ & $<0.8$ & 97.4 & 0.32 & 21.9 & 4.13 \\
\hline ST-141 & 1.7 & $<0.04$ & $<0.001$ & 0.033 & 1.77 & $<9$ & 629 & $<0.06$ & $<0.09$ & $<0.9$ & $<0.15$ & $<2.4$ & 296 & $<0.12$ & 52.1 & 41.4 \\
\hline CO-31 & 0.7 & 0.655 & $<0.001$ & 0.032 & 0.78 & $<3$ & 166 & 0.03 & $<0.03$ & $<0.3$ & $<0.05$ & $<1.6$ & 22.1 & $<0.04$ & 36.1 & 2.1 \\
\hline PE-59 & 3.05 & $<0.04$ & $<0.001$ & 0.087 & 3.35 & $<3$ & 111 & 0.02 & 0.067 & $<0.3$ & 0.051 & $<0.8$ & 282 & $<0.04$ & 8.09 & 12.7 \\
\hline MU-128 & 0.25 & $<0.04$ & $<0.001$ & 0.08 & 0.34 & $<3$ & 45.9 & $<0.02$ & $<0.03$ & $<0.3$ & 0.053 & $<0.8$ & 79.2 & 0.126 & 7.43 & 9.61 \\
\hline GR-755 & 26.9 & $<0.04$ & 0.001 & 0.806 & 27.9 & $<3$ & 523 & $<0.02$ & $<0.03$ & 0.37 & 0.381 & $<0.8$ & 3,730 & $<0.04$ & 0.98 & 39.6 \\
\hline MT-1286 & 0.15 & 0.298 & 0.006 & 0.006 & 0.49 & 3.2 & 99.6 & $<0.02$ & $<0.03$ & $<0.3$ & 0.109 & 2.4 & $<4$ & 0.15 & 14.3 & 7.93 \\
\hline DE-28 & 0.4 & $<0.04$ & $<0.001$ & 0.018 & 0.49 & 16.2 & 222 & 0.045 & 0.088 & $<0.3$ & $<0.05$ & $<0.8$ & 176 & $<0.04$ & 15 & 24.3 \\
\hline DE-29 & 0.4 & $<0.04$ & $<0.001$ & 0.038 & 0.5 & $<3$ & 307 & 0.047 & 0.108 & $<0.3$ & $<0.05$ & $<0.8$ & 653 & 0.139 & 26.1 & 32 \\
\hline HY-53 & 0.42 & $<0.04$ & $<0.001$ & 0.013 & 0.52 & $<3$ & 178 & 0.037 & 0.255 & $<0.3$ & $<0.05$ & $<0.8$ & 433 & 0.096 & 19 & 8.87 \\
\hline CR-63 & 0.73 & $<0.04$ & $<0.001$ & 0.008 & 0.9 & $<3$ & 99.4 & 0.064 & $<0.03$ & $<0.3$ & $<0.05$ & $<0.8$ & 11.7 & $<0.04$ & 70 & 32.6 \\
\hline
\end{tabular}


Table 5. Water-quality data from Ohio domestic wells, 2016.-Continued

[yyyymmdd, date in year-month-day format; mm Hg, millimeters mercury; ft, feet; BLS, below land surface; mg/L, milligrams per liter; $\mu \mathrm{S} / \mathrm{cm}$, microsiemens per centimeter; NTRU, nephelometric turbidity ratio unit; NAVD 88, North American Vertical Datum of 1988; $\mathrm{CaCO}_{3}$, calcium carbonate; U, hydrogen sulfide odor not detected; M, hydrogen sulfide odor detected; --, no data; N, nitrogen; P, phosphorus;

$<$, less than; As, arsenic; $\delta$, isotopic ratio delta notation; $\mathrm{C}$, carbon; DIC, dissolved inorganic carbon; per mil, parts per thousand; $\mathrm{CH}_{4, \text { methane }} ; \mathrm{H}$, hydrogen; $\mathrm{H}_{2} \mathrm{O}$, water; $\mathrm{O}$, oxygen]

\begin{tabular}{|c|c|c|c|c|c|c|c|c|c|c|c|c|c|c|c|}
\hline $\begin{array}{l}\text { Well } \\
\text { identifier }\end{array}$ & $\begin{array}{l}\text { Molybdenum } \\
\text { ( } \mu \mathrm{g} / \mathrm{L})\end{array}$ & $\begin{array}{c}\text { Nickel } \\
\text { ( } \mu \mathrm{g} / \mathrm{L})\end{array}$ & $\begin{array}{l}\text { Silver } \\
\text { ( } \mu \mathrm{g} / \mathrm{L})\end{array}$ & $\begin{array}{l}\text { Strontium } \\
(\mu \mathrm{g} / \mathrm{L})\end{array}$ & $\begin{array}{l}\text { Thallium } \\
\text { ( } \mu \mathrm{g} / \mathrm{L})\end{array}$ & $\begin{array}{l}\text { Vanadium } \\
\text { ( } \mu \mathrm{g} / \mathrm{L})\end{array}$ & $\begin{array}{l}\text { Zinc } \\
(\mu \mathrm{g} / \mathrm{L})\end{array}$ & $\begin{array}{c}\text { Antimony } \\
(\mu \mathrm{g} / \mathrm{L})\end{array}$ & $\begin{array}{c}\text { Arsenate } \\
\text { ( } \mu \mathrm{g} / \mathrm{L} \text { as } \\
\text { As) }\end{array}$ & $\begin{array}{c}\text { Arsenic } \\
(\mu \mathrm{g} / \mathrm{L})\end{array}$ & $\begin{array}{c}\text { Arsenite } \\
\text { ( } \mu \mathrm{g} / \mathrm{L} \text { as } \\
\text { As) }\end{array}$ & $\begin{array}{l}\text { Dimethyl- } \\
\text { arsinate } \\
\text { ( } \mu \mathrm{g} / \mathrm{L} \text { as } \\
\text { As) }\end{array}$ & 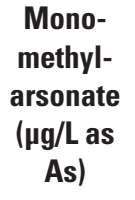 & $\begin{array}{l}\text { Boron } \\
(\mu \mathrm{g} / \mathrm{L})\end{array}$ & $\begin{array}{c}\text { Selenium } \\
(\mu \mathrm{g} / \mathrm{L})\end{array}$ \\
\hline AB-142 & 0.076 & $<0.2$ & $<0.02$ & 12.4 & $<0.03$ & 0.1 & $<2$ & $<0.027$ & $<0.4$ & $<0.1$ & $<0.2$ & $<0.3$ & $<0.8$ & 803 & $<0.05$ \\
\hline GE-368 & 0.519 & $<0.2$ & $<0.02$ & 35.1 & $<0.03$ & 0.84 & $<2$ & $<0.027$ & $<0.4$ & 0.18 & $<0.2$ & $<0.3$ & $<0.8$ & 359 & 0.06 \\
\hline SU-23 & 0.172 & 0.22 & $<0.02$ & 420 & $<0.03$ & $<0.1$ & 3.2 & $<0.027$ & 0.4 & 0.38 & $<0.2$ & $<0.3$ & $<0.8$ & 75 & $<0.05$ \\
\hline ST-140 & 0.074 & $<0.2$ & $<0.02$ & 392 & $<0.03$ & $<0.1$ & 251 & 0.028 & $<0.4$ & $<0.1$ & $<0.2$ & $<0.3$ & $<0.8$ & 276 & $<0.05$ \\
\hline ST-139 & 0.423 & $<0.2$ & $<0.02$ & 96.4 & $<0.03$ & 1.5 & 12.3 & $<0.027$ & $<0.4$ & 0.33 & $<0.2$ & $<0.3$ & $<0.8$ & 694 & 0.15 \\
\hline ST-141 & 0.702 & $<0.6$ & $<0.06$ & 724 & $<0.09$ & 0.6 & 8.4 & $<0.081$ & $<0.4$ & $<0.3$ & $<0.2$ & $<0.3$ & $<0.8$ & 614 & 0.53 \\
\hline CO-31 & 0.146 & $<0.4$ & $<0.02$ & 130 & $<0.06$ & $<0.1$ & $<2$ & $<0.027$ & $<0.4$ & $<0.1$ & $<0.2$ & $<0.3$ & $<0.8$ & 664 & 0.08 \\
\hline PE-59 & 15.9 & $<0.2$ & $<0.02$ & 447 & $<0.03$ & 0.38 & 3.1 & $<0.027$ & 0.8 & 34.1 & 31.5 & $<0.3$ & $<0.8$ & 394 & $<0.05$ \\
\hline MU-128 & 0.163 & $<0.2$ & $<0.02$ & 64.8 & $<0.03$ & 0.1 & 39.8 & 0.05 & $<0.4$ & 0.14 & $<0.2$ & $<0.3$ & $<0.8$ & 455 & 0.07 \\
\hline GR-755 & 0.216 & 0.66 & $<0.02$ & 1,270 & $<0.03$ & 0.75 & 20.8 & $<0.027$ & 5.1 & 39.5 & 32.5 & $<0.3$ & $<0.8$ & 112 & 0.08 \\
\hline MT-1286 & 1 & 0.71 & $<0.02$ & 560 & $<0.03$ & $<0.1$ & 7.6 & $<0.027$ & $<0.4$ & $<0.1$ & $<0.2$ & $<0.3$ & $<0.8$ & 437 & 0.32 \\
\hline DE-28 & 20.4 & $<0.2$ & 0.028 & 4,420 & $<0.03$ & 0.11 & $<2$ & $<0.027$ & $<0.4$ & $<0.1$ & $<0.2$ & $<0.3$ & $<0.8$ & 782 & $<0.05$ \\
\hline DE-29 & 26.4 & $<0.2$ & $<0.02$ & 4,210 & $<0.03$ & $<0.1$ & 270 & $<0.027$ & $<0.4$ & 0.16 & $<0.2$ & $<0.3$ & $<0.8$ & 786 & $<0.05$ \\
\hline HY-53 & 65.8 & $<0.2$ & $<0.02$ & 2,780 & $<0.03$ & $<0.1$ & 136 & $<0.027$ & $<0.4$ & $<0.1$ & $<0.2$ & $<0.3$ & $<0.8$ & 696 & 0.08 \\
\hline CR-63 & 0.057 & $<0.2$ & $<0.02$ & 6,860 & $<0.03$ & $<0.1$ & $<2$ & $<0.027$ & $<0.4$ & 0.111 & $<0.2$ & $<0.3$ & $<0.8$ & 1,370 & $<0.05$ \\
\hline
\end{tabular}


Table 5. Water-quality data from Ohio domestic wells, 2016.-Continued

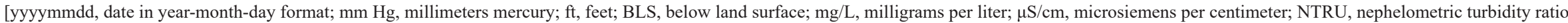
unit; NAVD 88, North American Vertical Datum of 1988; $\mathrm{CaCO}_{3}$, calcium carbonate; U, hydrogen sulfide odor not detected; M, hydrogen sulfide odor detected; --, no data; N, nitrogen; P, phosphorus;

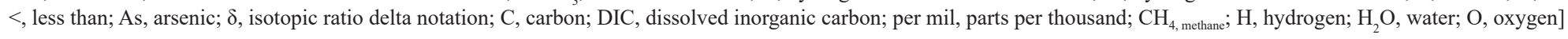

\begin{tabular}{|c|c|c|c|c|c|c|c|c|c|c|c|c|c|c|c|}
\hline $\begin{array}{c}\text { Well } \\
\text { identifier }\end{array}$ & $\begin{array}{l}\text { Uranium } \\
\text { ( } \mu \mathrm{g} / \mathrm{L})\end{array}$ & $\begin{array}{c}\text { Dissolved } \\
\text { organic } \\
\text { carbon } \\
\text { (mg/L) }\end{array}$ & $\begin{array}{c}\text { Argon } \\
\text { (mole } \\
\text { percent } \\
\text { of gases) }\end{array}$ & $\begin{array}{l}\text { Oxygen } \\
\text { (mole } \\
\text { percent } \\
\text { of gases) }\end{array}$ & $\begin{array}{l}\text { Nitrogen } \\
\text { (mole } \\
\text { percent } \\
\text { of gases) }\end{array}$ & $\begin{array}{c}\text { Carbon } \\
\text { dioxide } \\
\text { (mole } \\
\text { percent } \\
\text { of gases) }\end{array}$ & $\begin{array}{l}\text { Carbon } \\
\text { monoxide } \\
\text { (mole } \\
\text { percent of } \\
\text { gases) }\end{array}$ & $\begin{array}{l}\text { Hydrogen } \\
\text { (mole } \\
\text { percent } \\
\text { of gases) }\end{array}$ & $\begin{array}{l}\text { Helium } \\
\text { (mole } \\
\text { percent } \\
\text { of gases) }\end{array}$ & $\begin{array}{c}\text { Methane } \\
\text { (mole } \\
\text { percent } \\
\text { of gases) }\end{array}$ & $\begin{array}{c}\text { Ethane } \\
\text { (mole } \\
\text { percent } \\
\text { of gases) }\end{array}$ & $\begin{array}{c}\text { Ethene } \\
\text { (mole } \\
\text { percent } \\
\text { of gases) }\end{array}$ & $\begin{array}{c}\text { Propane } \\
\text { (mole } \\
\text { percent } \\
\text { of gases) }\end{array}$ & $\begin{array}{c}\text { Propene } \\
\text { (mole } \\
\text { percent } \\
\text { of gases) }\end{array}$ & $\begin{array}{c}\text { Iso- } \\
\text { butane } \\
\text { (mole } \\
\text { percent } \\
\text { of gases) }\end{array}$ \\
\hline AB-142 & $<0.014$ & 0.48 & 0.568 & 1.01 & 26.41 & 0.21 & $<0.01$ & $<0.01$ & -- & 71.79 & 0.0116 & $<0.0001$ & $<0.0001$ & $<0.0001$ & $<0.0001$ \\
\hline GE-368 & $<0.014$ & 0.42 & 0.319 & 0.61 & 12.9 & 0.051 & $<0.01$ & $<0.01$ & 0.013 & 86.09 & 0.02 & $<0.0001$ & $<0.0001$ & $<0.0001$ & $<0.0001$ \\
\hline SU-23 & $<0.014$ & 0.94 & 0.1 & 2.26 & 5.66 & 3.3 & $<0.01$ & $<0.01$ & -- & 73.21 & 12.41 & $<0.0001$ & 2.49 & $<0.0001$ & 0.205 \\
\hline ST-140 & $<0.014$ & 0.45 & 1.25 & 2.06 & 61.19 & 3.2 & $<0.01$ & $<0.01$ & -- & 32.28 & 0.0177 & $<0.0001$ & $<0.0001$ & $<0.0001$ & $<0.0001$ \\
\hline ST-139 & $<0.014$ & 0.36 & 0.409 & 0.67 & 19.47 & 0.37 & $<0.01$ & $<0.01$ & 0.012 & 79.06 & 0.0125 & $<0.0001$ & $<0.0001$ & $<0.0001$ & $<0.0001$ \\
\hline ST-141 & $<0.042$ & 1.38 & 0.131 & 0.66 & 5.39 & 1.07 & $<0.01$ & $<0.01$ & 0.009 & 92.68 & 0.0571 & $<0.0001$ & 0.0001 & $<0.0001$ & $<0.0001$ \\
\hline $\mathrm{CO}-31$ & $<0.014$ & 3.6 & 0.161 & 1.39 & 5.9 & 0.76 & $<0.01$ & $<0.01$ & 0.009 & 91.76 & 0.0234 & $<0.0001$ & $<0.0001$ & $<0.0001$ & $<0.0001$ \\
\hline PE-59 & $<0.014$ & 2.67 & 0.588 & 2.66 & 31.1 & 0.94 & $<0.01$ & $<0.01$ & -- & 64.41 & 0.266 & $<0.0001$ & 0.0372 & $<0.0001$ & 0.0028 \\
\hline MU-128 & $<0.014$ & 1.57 & 0.307 & 2.35 & 15.97 & 1.41 & $<0.01$ & $<0.01$ & -- & 79.9 & 0.0663 & $<0.0001$ & $<0.0001$ & $<0.0001$ & $<0.0001$ \\
\hline GR-755 & $<0.014$ & 16.2 & 0.221 & 0.28 & 7.82 & 5.33 & $<0.01$ & $<0.01$ & 0.01 & 86.34 & 0.0029 & $<0.0001$ & $<0.0001$ & $<0.0001$ & $<0.0001$ \\
\hline MT-1286 & 0.706 & 0.85 & 1.43 & 3.29 & 70.77 & 18.84 & $<0.01$ & $<0.01$ & -- & 5.46 & 0.154 & $<0.0001$ & 0.0414 & $<0.0001$ & 0.0076 \\
\hline DE-28 & $<0.014$ & 0.86 & 0.453 & 2.83 & 21.2 & 0.62 & $<0.01$ & $<0.01$ & 0.008 & 74.89 & 0.0026 & $<0.0001$ & $<0.0001$ & $<0.0001$ & $<0.0001$ \\
\hline DE-29 & $<0.014$ & 2.58 & 0.159 & 1.06 & 7.03 & 0.98 & $<0.01$ & $<0.01$ & 0.006 & 90.76 & 0.009 & $<0.0001$ & $<0.0001$ & $<0.0001$ & $<0.0001$ \\
\hline HY-53 & $<0.014$ & 1.03 & 0.091 & 1.87 & 3.87 & 0.85 & $<0.01$ & $<0.01$ & -- & 93.31 & 0.0042 & $<0.0001$ & 0.0002 & $<0.0001$ & $<0.0001$ \\
\hline CR-63 & 0.0812 & 1.52 & 0.92 & 0.039 & 45.32 & 3.77 & $<0.01$ & $<0.01$ & -- & 49.86 & 0.0947 & $<0.0001$ & $<0.0001$ & $<0.0001$ & $<0.0001$ \\
\hline
\end{tabular}


Table 5. Water-quality data from Ohio domestic wells, 2016.-Continued

[yyyymmdd, date in year-month-day format; mm Hg, millimeters mercury; ft, feet; BLS, below land surface; mg/L, milligrams per liter; $\mu \mathrm{S} / \mathrm{cm}$, microsiemens per centimeter; NTRU, nephelometric turbidity ratio unit; NAVD 88, North American Vertical Datum of 1988; $\mathrm{CaCO}_{3}$, calcium carbonate; U, hydrogen sulfide odor not detected; M, hydrogen sulfide odor detected; --, no data; N, nitrogen; P, phosphorus;

$<$, less than; As, arsenic; $\delta$, isotopic ratio delta notation; $\mathrm{C}$, carbon; DIC, dissolved inorganic carbon; per mil, parts per thousand; $\mathrm{CH}_{4, \text { methane }} ; \mathrm{H}$, hydrogen; $\mathrm{H}_{2} \mathrm{O}$, water; $\mathrm{O}$, oxygen]

\begin{tabular}{|c|c|c|c|c|c|c|c|c|c|c|c|c|c|c|}
\hline $\begin{array}{c}\text { Well } \\
\text { identifier }\end{array}$ & $\begin{array}{l}\text { n-Butane } \\
\text { (mole } \\
\text { percent } \\
\text { of gases) }\end{array}$ & $\begin{array}{c}\text { Iso- } \\
\text { pentane } \\
\text { (mole } \\
\text { percent of } \\
\text { gases) }\end{array}$ & $\begin{array}{l}\text { n-Pentane } \\
\text { (mole } \\
\text { percent of } \\
\text { gases) }\end{array}$ & $\begin{array}{l}\text { Hexanes }^{+} \\
\text {(mole } \\
\text { percent of } \\
\text { gases) }\end{array}$ & $\begin{array}{c}\text { Methane } \\
\text { (mg/L) }\end{array}$ & $\begin{array}{l}\text { Ethane } \\
(\mathrm{mg} / \mathrm{L})\end{array}$ & $\begin{array}{c}\text { Propane } \\
\text { (mg/L) }\end{array}$ & $\begin{array}{c}\delta^{13} \mathbf{C}_{\text {DIC }} \\
\text { (per mil) }\end{array}$ & $\begin{array}{c}\delta^{13} \mathrm{C}_{\mathrm{CH}_{4}} \\
\text { (per mil) }\end{array}$ & $\begin{array}{c}\delta^{2} \mathrm{H}_{\mathrm{CH}_{4}} \\
\text { (per mil) }\end{array}$ & $\begin{array}{l}{ }^{14} \mathrm{C}_{\mathrm{CH}_{4}} \\
\text { (percent } \\
\text { modern } \\
\text { carbon) }\end{array}$ & $\begin{array}{c}{ }^{14} \mathrm{C}_{\mathrm{CH}_{4}} \\
\text { standard } \\
\text { deviation } \\
\text { (percent } \\
\text { modern } \\
\text { carbon) }\end{array}$ & $\begin{array}{c}\delta^{2} \mathrm{H}_{\mathrm{H}_{2} \mathrm{O}} \\
\text { (per mil) }\end{array}$ & $\begin{array}{c}\delta^{18} \mathbf{O}_{\mathrm{H}_{2} \mathbf{0}} \\
\text { (per mil) }\end{array}$ \\
\hline AB-142 & $<0.0001$ & $<0.0001$ & $<0.0001$ & $<0.0001$ & 36 & 0.012 & $<0.0002$ & -6 & -75.19 & -252.6 & 13.5 & 0.1 & -58.1 & -8.86 \\
\hline GE-368 & $<0.0001$ & $<0.0001$ & $<0.0001$ & $<0.0001$ & 73 & 0.035 & $<0.0002$ & -8.8 & -64.31 & -245.3 & $<0.4$ & -- & -60.0 & -9.25 \\
\hline SU-23 & 0.251 & 0.0523 & 0.0362 & 0.0228 & 39 & 13 & 3.7 & -2.9 & -47.74 & -236.7 & 1.6 & 0.1 & -59.2 & -9.14 \\
\hline ST-140 & $<0.0001$ & $<0.0001$ & $<0.0001$ & $<0.0001$ & 8.7 & 0.0097 & $<0.0002$ & -8.9 & -69.85 & -243.5 & 1.5 & 0.1 & -55.4 & -8.54 \\
\hline ST-139 & $<0.0001$ & $<0.0001$ & $<0.0001$ & $<0.0001$ & 57 & 0.019 & $<0.0002$ & 3 & -69.11 & -237.1 & $<0.4$ & -- & -53.6 & -8.37 \\
\hline ST-141 & $<0.0001$ & $<0.0001$ & $<0.0001$ & $<0.0001$ & 120 & 0.14 & 0.0003 & 10.8 & -62.46 & -241.9 & $<0.4$ & -- & -57.3 & -8.69 \\
\hline $\mathrm{CO}-31$ & $<0.0001$ & $<0.0001$ & $<0.0001$ & $<0.0001$ & 98 & 0.05 & $<0.0002$ & 18.9 & -61.19 & -253.8 & $<0.4$ & -- & -77.4 & -11.54 \\
\hline PE-59 & $<0.0001$ & 0.0006 & $<0.0001$ & $<0.0001$ & 36 & 0.3 & 0.059 & -9.4 & -69.55 & -240.2 & 0.9 & 0.1 & -49.70 & -7.95 \\
\hline MU-128 & $<0.0001$ & $<0.0001$ & $<0.0001$ & $<0.0001$ & 29 & 0.049 & $<0.0002$ & -13 & -67.48 & -206 & $<0.4$ & -- & -50.20 & -7.78 \\
\hline GR-755 & $<0.0001$ & $<0.0001$ & $<0.0001$ & $<0.0001$ & 80 & 0.0054 & $<0.0002$ & 2.6 & -71.37 & -232.1 & $<0.4$ & -- & -48.00 & -7.28 \\
\hline MT-1286 & 0.0063 & 0.0009 & $<0.0001$ & $<0.0001$ & 1.2 & 0.068 & 0.025 & -14.8 & -50.96 & -230.7 & -- & -- & -47.10 & -7.15 \\
\hline DE-28 & $<0.0001$ & $<0.0001$ & $<0.0001$ & $<0.0001$ & 47 & 0.0034 & $<0.0002$ & 8.9 & -70.17 & -252.3 & 1.7 & 0.1 & -57.0 & -8.51 \\
\hline DE-29 & $<0.0001$ & $<0.0001$ & $<0.0001$ & $<0.0001$ & 91 & 0.018 & $<0.0002$ & 12 & -59.45 & -276.6 & $<0.4$ & -- & -74.3 & -10.93 \\
\hline HY-53 & $<0.0001$ & $<0.0001$ & $<0.0001$ & $<0.0001$ & 45 & 0.0041 & 0.0003 & 16.8 & -56.8 & -285.7 & $<0.4$ & -- & -114.6 & -16.05 \\
\hline CR-63 & $<0.0001$ & $<0.0001$ & $<0.0001$ & $<0.0001$ & 17 & 0.066 & $<0.0002$ & -31.6 & -59.04 & -220.7 & 1.3 & 0.2 & -52.8 & -8.12 \\
\hline
\end{tabular}


For additional information, contact:

Director, Ohio-Kentucky-Indiana Water Science Center

U.S. Geological Survey

6460 Busch Boulevard Ste. 100

Columbus, $\mathrm{OH}$ 43229-1737

Publishing support provided by the Madison and Rolla Publishing Service Centers 


\section{$\frac{\mathbb{2}}{3}$}

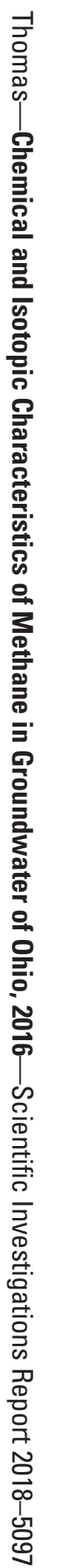

